\title{
Characterisation of solvent extractable organic constituents in atmospheric particulate matter: an overview
}

\author{
CÉLIA A. ALVES \\ Centre for Environmental and Marine Studies, Department of Environment, University of Aveiro, 3810-193 Aveiro, Portugal \\ Manuscript received on May 3, 2007; accepted for publication on July 12, 2007; \\ presented by FERNANDO GALEMBECK
}

\begin{abstract}
In spite of accounting for $10-70 \%$ of the atmospheric aerosol mass, particulate-phase organic compounds are not well characterised, and many aspects of aerosol formation and evolution are still unknown. The growing awareness of the impact of particulate aerosols on climate, and the incompletely recognised but serious effects of anthropogenic constituents on air quality and human health, have conducted to several scientific studies. These investigations have provided information about the behaviour of atmospheric particulate matter and the description of the character of its carbonaceous content. The compilation of such results is important as they append to the emergent global-wide dataset of the organic composition of atmospheric aerosols. The contribution of the major emission sources to regional particulate pollution can be diagnosed by using specific molecular markers. This overview is mainly focused on results obtained with gas chromatography coupled with mass spectrometry, since it is the analytical method of choice in elucidating the solvent-extractable organic compounds in atmospheric particulate matter. A synopsis of the selection of organic tracers and the application of geochemical parameters to the analysis of organic constituents as a tool for source apportionment is shown here. Besides the assessment of current knowledge, this paper also presents the identification of further areas of concern.
\end{abstract}

Key words: atmospheric aerosol, gas chromatography-mass spectrometry, organic compounds, source apportionment, tracers.

\section{INTRODUCTION}

Aerosols are mixtures of solid and liquid droplets of material that vary in size and origin. Airborne suspended particulate matter can be either primary or secondary in nature. Primary particles are emitted directly into the atmosphere both by natural or anthropogenic sources, while secondary particles are produced in the atmosphere from the oxidation and subsequent reactions of sulphur dioxide, nitrogen oxides and volatile organic compounds. Primary biogenic aerosols are particles that are produced by the crumbling and dispersion of plant and animal material, and the spreading of microbes from a variety of surfaces into the atmosphere. Industrialisation, human

E-mail: celia.alves@ua.pt activities and the growing levels of traffic result in an anthropogenic sources prevalence, particularly in urban areas (Alves et al. 2007). Mass and composition tend to be divided into two main groups: coarse particles and fine particles. The barrier between coarse and fine particulate matter is sometimes fixed by convention at $2.5 \mu \mathrm{m}$ in aerodynamic diameter for measurement purposes. Thus, two categories of particle pollution may be addressed: (i) fine particles $\left(\mathrm{PM}_{2.5}\right)$, which are $2.5 \mu \mathrm{m}$ in diameter and smaller; and (ii) inhalable coarse particles $\left(\mathrm{PM}_{10-2.5}\right)$, which are smaller than $10 \mu \mathrm{m}$ in diameter, but larger than $\mathrm{PM}_{2.5}$. The smaller particles contain the secondarily formed aerosols (gas-to-particle conversion), combustion particles and recondensed organic and metal vapours. The larger particles generally include 
earth crust materials and fugitive dust from roads and industries. The fine fraction encompasses most of the acidity (hydrogen ion) and mutagenic activity of particulate matter, although in fog some coarse acid droplets are also present. The major aerosol components include inorganic substances such as sulphates and carbonaceous species. The carbonaceous aerosol is formed by a complex mixture of organic compounds, normally referred as organic carbon (OC), and a mass of carbon atoms with a graphitic-like structure that is black in colour and is normally named as soot, black carbon or elemental carbon (BC or EC). Organic matter is an important fraction of the atmospheric aerosols, contributing with $10-70 \%$ of their mass (Turpin et al. 2000).

Atmospheric PM is an environmental concern, above all because it can dramatically reduce visual range (Hobbs 2002), and have a profound effect on climate (Penner et al. 1998). The direct and indirect radiative forcing of climate by anthropogenic aerosols is believed to be similar in magnitude but opposite in sign to the global warming caused by the emissions of greenhouse gases (Farquhar 1997, Mahlman 1997). Fine particles and the associated organic compounds are also of current concern because of their putative health effects (Abelson 1998, Pope et al. 2004, Poschl 2005). There is a general consensus that the organic composition of atmospheric aerosol should be understood to correctly describe the chemical mechanisms and models concerning the multiphase atmospheric system and to evaluate its environmental and health effects. Despite the progress made in elucidating the source types, their relative importance and contribution to certain particulate components, the organic composition of aerosols and particle formation processes are still scarcely known. This is probably due to analytical difficulties, complexity of phenomena and huge number of compounds that are present (Alves et al. 2006).

The objective of this paper is to contribute to clarifying the role and importance of the carbonaceous aerosol in the environment by answering to questions such as: Which are the sources of the carbonaceous aerosol? Which are the best tracers to track the contributions of the main sources? Is the organic aerosol of primary or secondary origin? How much of the organic carbon is extractable and identifiable by common laboratory equipments used for organic speciation (e.g. gas chromatograph/mass spectrometer)? Is it possible to close the material balance of the organic aerosol? Which are the organic constituents that we haven't been able to quantify? What problems are ripe for further investigation? The discussion of these points constitutes the main goal of the present review study. A comparison of recent results obtained in different researches throughout the world and the limitations that still persist are presented.

\section{METHODOLOGIES FOR THE DETERMINATION OF ORGANIC AEROSOL COMPOSITION}

A variety of methods have been used to typify the organic composition of atmospheric aerosols. These methods may be separated into integral methods that characterise only some properties of organic particulate matter, such as OC content, functional groups, isotope ratios, etc., and molecular-level methods that allow the speciation of individual organic compounds. Organic compound speciation affords the most helpful information about organic aerosol composition, sources, and atmospheric transformation processes. At present it is not possible to entirely resolve all OC mass into concentrations of specific organic compounds and no sole analytical technique is proficient of analysing the whole organic composition. The molecular level methods typically have need of extraction of a sample with organic solvents, followed by analysis by gas chromatography/mass spectrometry (GC/MS), gas chromatography/Fourier transform infrared spectroscopy/mass spectrometry (GC/ FTIR/MS), high performance liquid chromatography/ mass spectrometry (HPLC/MS) and other techniques. Traditionally, chemical characterisation of particulate OC has been performed using single or multiple solvent extractions of samples followed by GC/MS (Facchini et al. 1999, Gogou et al. 1998, Plewka et al. 2003, Rissanen et al. 2006, Sin et al. 2002, Zappoli et al. 1999). However, in these experimental works a significant portion of polar oxygenated organic compounds remains unknown. Identified organic compounds in aerosol typically account for $10 \%$ or less of the mass of total OC measured by thermal analysis, although this percentage could reach values above $60 \%$, when more complex extraction methodologies and detection techniques are used (Alves et al. 2002, 2006, Carvalho et al. 2003, Dece- 
sari et al. 2000, Feng et al. 2007). This is because universal solvents for both polar and non-polar OC do not exist, high-molecular organics $\left(>\mathrm{C}_{40}\right)$ and highly polar compounds (particularly multifunctional) do not elute through a GC column and identified compounds are embedded in an unresolved complex mixture. Polar organic compounds need derivatisation prior to analysis, to convert them into less polar and more volatile derivatives that will elute chromatographically. However, the derivatisation techniques are compound-class specific and thus several different methods may be required for a wide-ranging analysis. On the other hand, since derivatisation procedures are compound-class specific, require a priori knowledge about the particulate matter composition. The derivatisation reagent by-products, the complexity of derivatisation procedures, lack of standards, and limited mass spectral libraries makes these analyses difficult and time consuming. The combined GC/FTIR/MS technique offers the advantage of additional information from the FTIR spectrum, complementary to mass spectrum information, and is helpful in identification of individual components, especially isomers; often these compounds have very similar mass spectra, but unique IR spectra (Zielinska 2002).

HPLC coupled with a mass spectrometer or a photodiode array detector seems to be especially suitable for the analysis of polar organic compounds. Aqueous solutions can be injected into reverse-phase columns, and polar compounds do not need a derivatisation step in order to elute from most of the LC columns (Zielinska 2002). However, compared with GC and GC/MS, HPLC has infrequently been used for the study of organic aerosol (Jacobson et al. 2000). This is perhaps because LC columns present less resolving power than GC columns and are habitually intended for restrict organic classes. Moreover, even though that numerous commercial LC/MS systems are available, they are not properly developed for atmospheric investigation. From the two types of interfaces available between LC and MS, electrospray and particle beam, the last one seems to be more promising (Kiss et al. 2003). Additional progress of separation methods and mass spectral libraries is also essential.

Sierau et al. (2003) developed a method for rapid measurement of particle size and chemical composition.
The method uses a saturator/condenser system and an impactor; the saturator/condenser system grows submicrometer particles to a size where they can be easily collected by the impactor. This system was called condensation-growth and impaction system, or C-GIS. To do size-segregated analysis, an optional differential mobility analyser (DMA) can be added upstream of the C-GIS to select the particle size that is introduced into the condenser. The C-GIS converts the sampled aerosol into a hydrosol, and provides liquid samples sufficiently concentrated for the liquid-phase analytical instruments used for chemical analysis without on-line pre-concentration of the sample. The results indicate that the $\mathrm{C}$ GIS can be used for size-segregated particle sampling with subsequent off-line chemical particle analysis with a sampling time of at least 20 min under typical atmospheric conditions. For atmospheric applications, however, its capability to rapidly measure size-segregated chemical composition is limited by the particle concentration present downstream of the DMA, and therefore, such measurements typically can only be made in heavily polluted areas or within the scope of source-characterisation studies.

Several novel methods have lately been proposed for a molecular-level organic aerosol speciation. Neusüss and co-workers (2000) employed flash evaporation by Curie point pyrolysis coupled with GC/MS (CPP-GC/ $\mathrm{MS}$ ) for direct analysis of atmospheric semi-volatile organic constituents. The benefit of this method is that only a few micrograms of sample are required, permitting its utilisation with size-segregated sampling without posterior sample preparation. The inconvenience is that very polar organic compounds may either not elute from a GC column, or be shattered during the flash evaporation process. To overcome this difficulty, the same investigators recommend using complementarily capillary electrophoresis (CE) for analysis of dicarboxylic and hydroxy dicarboxylic acids. The system also enables the analysis of common inorganic ions and methanesulfonate. Because of their different electrophoretic mobilities, in $\mathrm{CE}$, ions are separated in a strong electric field. The possibility of analysing both inorganic and organic ions in a single run represents an advantage of this method in comparison with ion chromatography and GC or HPLC. In addition, the separation efficiency is 
higher than in LC and the required sample amount is very low (Zielinska 2002). Thermal desorption particle beam mass spectrometry has been lately developed and employed for identification of secondary organic aerosol constituents produced in environmental chambers (Tobias and Ziemann 2000). In this method, a number of particles are trapped on a cold step and gradually heated, to separate compounds depending on their volatility. This analytical equipment presents a large capability for identification of organic compounds formed in controlled laboratory experiments. However, its resolving power to identify and quantify single compounds within a complex organic mixture, as observed in atmospheric aerosols, is very limited. Recently, several researchers have developed instruments for real-time in situ analysis of single particles, including carbon analysers and single particle instruments to fragment each particle into ions using either a high-power laser or a heated surface and to then use a time-of-flight mass spectrometer for measuring the ion fragments in a vacuum (Guyon et al. 2004, Johnston and Wexler 1995, Silva and Prather 1997, Thompson and Murphy 1994, Turpin and Huntzicker 1995). Direct thermal desorption - gas chromatography - time-of-flight mass spectrometry (DTDGC-TOFMS) and comprehensive two-dimensional (2D) gas chromatography - time-of-flight mass spectrometry $(\mathrm{GC} \times \mathrm{GC}$-TOFMS) was applied by Welthagen et al. (2003) for characterisation of semi-volatile organic compounds in $\mathrm{PM}_{2.5}$. These investigators concluded that $\mathrm{GC} \times \mathrm{GC}-\mathrm{TOFMS}$ is a suited technique to study the nature of the yet unidentified compounds forming the unresolved complex mixtures (UCM). The considerably increased chromatographic resolution in $\mathrm{GC} \times \mathrm{GC}$ allows separation of many UCM compounds while the TOFMS supplies mass spectral data of all separated compounds. However, the data sets were considered enormously complex. In the near future in situ single-particle TOFMS analysis methods are unlikely to quantify, compound by compound, the concentration of a large (50-100\%) fraction of organic material in atmospheric PM (Turpin et al. 2000). Generally these instruments are more appropriate for inorganic than organic species, but the future technical development could surmount this panorama.

One important objective of detailed chemical analysis of the organic aerosol is the mass closure of the aerosol mass. Until now it has been impossible to identify and quantify all the organic mass present in the atmospheric aerosol. Little is known about the type and abundance of water-soluble organic compounds (WSOC) in atmospheric particulate matter. The limited results available to date indicate that WSOC could account for $20-90 \%$ of total carbon in aerosols (Alves et al. 2002, Decesari et al. 2000, 2001, Facchini et al. 1999, Graham et al. 2002, Saxena and Hildemann 1996). Yang et al. (2003) compared two methods for the determination of WSOC in ambient aerosols, one based on a total organic carbon analyser (TOC) and the other based on an aerosol carbon analyser (ACA). Investigators concluded that, although the sample treatment procedures and the detection limits of these two methods are different to some extent, both are suitable for the determination of WSOC in aerosol samples. Recently, some studies have attempted the most abundant WSOC in fog water and aerosols. Decesari et al. $(2000,2001)$ and Fuzzi et al. (2001) used ion exchange chromatography and proton nuclear magnetic resonance spectroscopy (HNMR) to characterise the WSOC in atmospheric aerosols, fog and cloud droplets. Zappoli et al. (1999) have shown that a substantial part of the organic aerosol is not soluble in water and organic solvents, indicating that insoluble compounds are of larger molecular sizes. The organic aerosol according to current knowledge are the "Humic Like Substances" (HULIS), occurring in the aerosol as water soluble as well as water insoluble fractions. Different extraction procedures and detection methods were presented in the literature. Spectroscopic methods such as ultraviolet, fluorescence, or infrared spectroscopy were most often used to characterise this organic mass fraction, but electrospray ionisation mass spectroscopy and laser desorption/ionisation mass spectrometry (LDI/MS) were used as well (Havers et al. 1998, Kalberer et al. 2004, 2006, Kiss et al. 2003, Krivácsy et al. 2001, Samburova et al. 2005, Varga et al. 2001, Zappoli et al. 1999). Because of the large number of compounds detected with mass spectrometric methods (Kiss et al. 2003, Samburova et al. 2005), and because the chemical properties of these compounds are mostly unknown, it is difficult to determine their concentration or their molecular weight distribution (Kalberer et al. 2006). 


\section{GC/MS CHARACTERISATION STUDIES}

GC/MS has by far been the most common means of identifying organic compounds in atmospheric aerosol. The motive is that GC can be used to separate a very ample range of compounds on a single column, and the simple on-line coupling to mass spectrometry (usually electron-impact quadrupole) makes compound identification rather easy. The preliminary GC/MS results on atmospheric organic particulate matter were obtained at the end of the seventies and beginning of the eighties. However, the content of these works were focused mainly on practical details, such as the evaluation of the analytical methodologies of solvent extraction, and did not attempt to present an exhaustive description of the aerosol composition (Barkenbus et al. 1983a, b, Cautreels and Cauwenberghe 1977, Hill et al. 1977, Karasek et al. 1978, Ketseridis et al. 1976, Wauters et al. 1979). If chemical analysis is performed using a chromatographic method, aerosols collected on filters or impactor plates are subjected to an extraction procedure (ultrasonication, Soxhlet, supercritical fluid $\mathrm{CO}_{2}$ extraction, etc.). An example illustrating the entire procedure is provided in Figure 1. Thermal/optical carbon analysis (TOC) is a technique for separating and measuring the total amount of organic and elemental carbon, commonly from quartz filter samples. This determination is essential in any study that involves extraction of material from filters because it permits measurement of the extraction efficiency. The filter sample is placed into a chamber and heated in the presence of one or more purge gases through a succession of temperature steps. A catalyst converts the evolved gases to either $\mathrm{CO}_{2}$ or $\mathrm{CH}_{4}$, which are quantified using infrared or flame ionisation detection, respectively. In most of the thermal evolution techniques, the division between organic and elemental carbon is based on the temperature and/or the type of purge gas used for analysis (Birch 1998, Birch and Cary 1996, Cadle and Mulawa 1990, Carvalho et al. 2006, Chow et al. 1993, 2001, 2004, 2005, Conny et al. 2003, Venkatachari et al. 2006, Watson and Chow 2002). OC is generally defined as the non-carbonate carbon that evolves under a heating cycle in the presence of either $\mathrm{He}$ or $\mathrm{N}_{2}$, and EC is defined as that which evolves in a succeeding heating step in the presence of a gas mixture including oxygen, such as $98 \% \mathrm{He}+2 \% \mathrm{O}_{2}$ (Birch and Cary 1996, Chow et al. 1993, 2001, Schauer et al. 2003a). It should be noted that some organic compounds pyrolyse or "char" before they are evolved under the $\mathrm{He} / \mathrm{O}_{2}$ part of the analysis. The char that is produced in the analysis, if not accurately accounted for, would be erroneously reported as EC present in the original sample (Schauer et al. 2003a). Usually, a laser absorbance procedure is used to correct for charring in thermo-optical methods.

The knowledge gained through testing experimental procedures began to be applied to the detailed characterisation of aerosols emitted by specific sources or activities, such as volcanic eruptions (Pereira et al. 1982), meat cooking operations (Hildemann et al. 1991, Kleeman et al. 1999, Nolte et al. 1999, Rogge et al. 1991, Schauer et al. 1999a), road dust and tire debris (Rogge et al. 1993a), particulate abrasion products from leaf surfaces of urban plants (Chen and Simoneit 1994, Rogge et al. 1993b), home boilers (Hildemann et al. 1991, Rogge et al. 1993c, 1997a), hot asphalt roofing tar plot plumes (Rogge et al. 1997b), biomass burning (Abas et al. 1995, 2004a, Duan et al. 2004, Elias et al. 1997, 1998, Fang et al. 1999, Fine et al. 2001, 2002a, b, 2004a, Jayaratne and Verna 2001, Jordan et al. 2006, Kleeman et al 1999, Oros and Simoneit 2001a, b, Rogge et al. 1998, Schauer et al. 2001, Simoneit 2002, Simoneit and Elias 2001, Simoneit et al. 1993, 1996, 1999, 2000, Standley and Simoneit 1994), motorised vehicles (Fraser et al. 1999, Hildemann et al. 1991, Rogge et al. 1993d, Schauer et al. 1999b, Simoneit 1984), tobacco smoke (Kavouras et al. 1998a, Kleeman et al. 1999, Morrical and Zenobi 2002, Rogge et al. 1994), coal-fired power station (Santos et al. 2004), waste landfill (Yassaa et al. 2001a) and eolian transport of vegetal detritus (Boon et al. 1998, Simoneit 1997, Simoneit et al. 1988). Some of the researches have also focused upon the assessment of natural versus anthropogenic contributions to the carbonaceous aerosol by searching molecular markers or tracers (Abas et al. 1995, 2004a, b, Alves and Pio, in press, Cass 1998, Elias et al. 1999, Fraser et al. 1999, Gogou et al. 1996, 1998, Hawthorne et al. 1988, Kavouras et al. 2001a, Khalil and Rasmussen 2003, Lau et al. 2006, Li and Kamens 1993, Nolte et al. 2001, 2002, Oros et al. 1999, Oros and Simoneit 2001a, b, Rinehart et al. 2006, Rogge et al. 2006, Rushdi et al. 


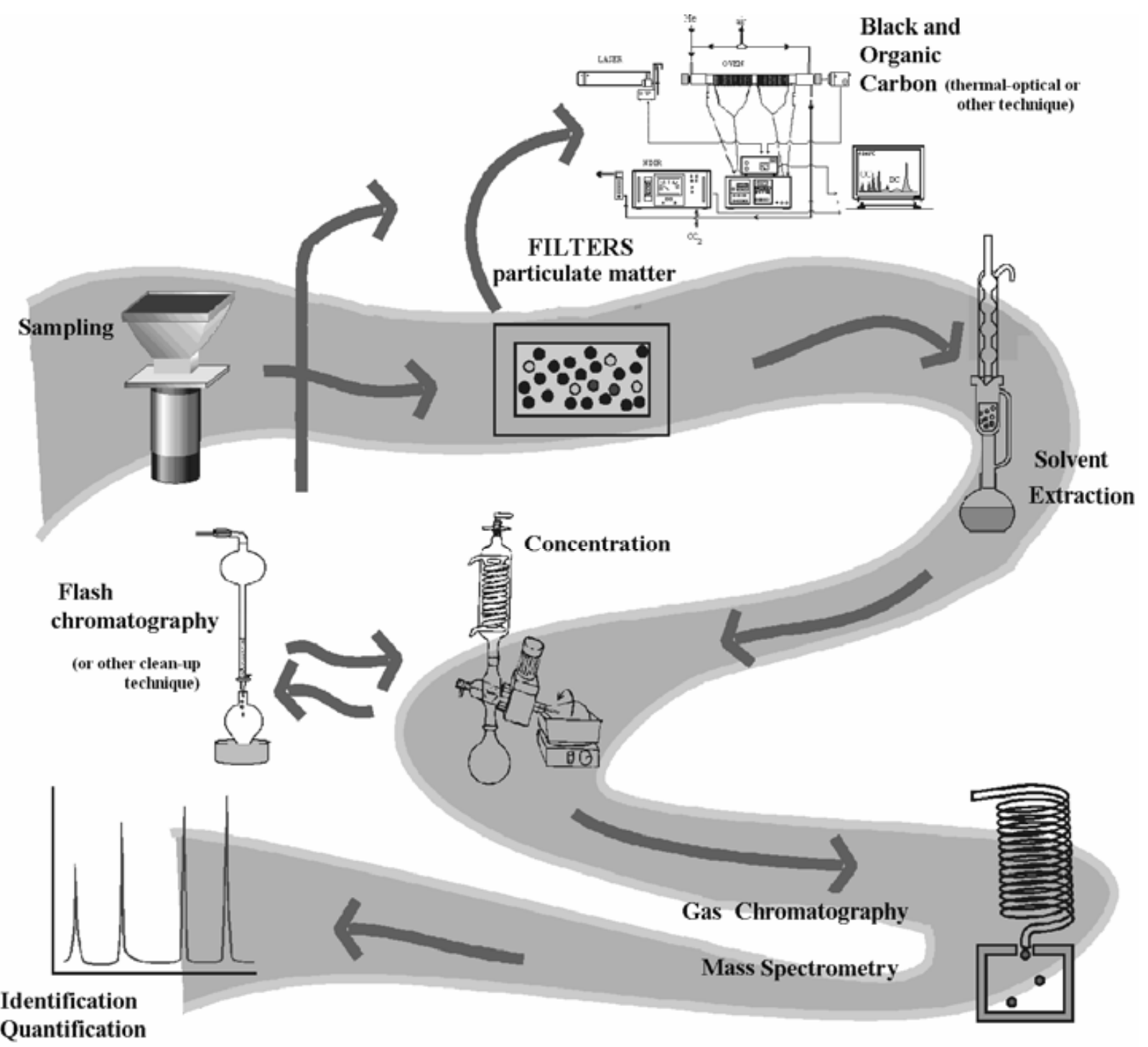

Fig. 1 - Scheme representing a common sampling, extraction and GC/MS procedure for organic speciation of atmospheric aerosols.

2003, Schauer et al. 1996, Sheesley et al. 2003, Simoneit 1989, 1999, 2002, Simoneit and Elias 2001, Simoneit and Mazurek 1989, Simoneit et al. 1990, 1993, 1996, 1999, 2003a, b, 2004a, b, Standley and Simoneit 1994, Zheng et al. 2002). Source-receptor reconciliation by chemical mass balance (CMB) has been used to characterise the composite sources of organic compounds that includes gasoline vehicle exhaust, meat cooking, cigarette smoke, wood burning, etc. (Calhoun et al. 2003, Chow and Watson 2002, Feng et al. 2006, Khalil and Rasmussen 2003, Li and Kamens 1993, Mazurek 2002, Robinson et al. 2006a, b, Schauer et al. 2002a, Watson et al. 2002, Zheng et al. 2002, 2005).

Such as it happens with the OC and EC determinations, most of the investigations to date on the characterisation of organic aerosols deal almost exclusively with urban samples. The scientific literature of the last two decades comprehends several works which report the particulate matter analyses for different metropolis: Heraclion, Crete (Gogou et al. 1996, Stephanou and Stratigakis 1993), Hong Kong (Zheng et al. 1997, 2000, Lee et al. 2001, Yu et al 2004), cities in the PanJapan Sea countries (Kawamura and Yasui 2005, Tang et al. 2005), Algiers city area (Yassaa et al. 2001b), 
Chinese urban areas (Bi et al. 2002, 2003, Cao et al. 2003, 2004, Duan et al. 2004, Guo et al. 2003, 2004, Hou et al. 2006, Simoneit et al. 1991a, Yang et al. 2005a, Wang et al. 2002, 2006a, b, 2007, Wang and Kawamura 2005, Zheng et al. 2005), Barcelone (Aceves and Grimalt 1992, 1993), London (Kendall et al. 2001), Houston, Texas (Fraser et al. 2002, Laurent and Allen 2004, Yue and Fraser 2004), Miami, Florida (Lang et al. 2002), Kuala Lumpur, Malaysia (Abas et al. 2004b, Abas and Simoneit 1996), Toronto (Blanchard et al. 2002), Prato, Italy (Cincinelli et al. 2003), Launceston, Australia (Keywood et al. 2000), Santiago, Chile (Didyk et al. 2000, Kavouras et al. 1999a, 2001a, Romero et al. 2002, Tsapakis et al. 2002), Temuco, Chile (Tsapakis et al. 2002), Oporto, Portugal (Oliveira et al. 2007a), Gent, Belgium (Kubátová et al. 2002), Birminghan, UK (Harrad et al. 2003), Helsinki, Finland (Kallio et al. 2003), Copenhagen (Oliveira et al. 2007a), the Brazilian cities of Rio de Janeiro (Azevedo et al. 1999), Campo Grande (Ré-Poppi and Santiago-Silva 2002), São Paulo (Vasconcellos et al. 2003) and Campos dos Goytacazes (Azevedo et al. 2002), Philadelphia (Li et al. 2006), Seattle (Kim et al. 2004) and Tel Aviv, Israel (Graham et al. 2004). However, the Los Angeles metropolitan area represents, incontestably, the one that is favoured by a higher number of studies on organic composition of atmospheric aerosols (Fine et al. 2004b, Fraser et al. 1997, 1999, Hildemann et al. 1994, 1996, Lough et al. 2006, Manchester-Neesvig et al. 2003, Rinehart et al. 2006, Rogge et al. 1993e, 1996, Schauer et al. 2002a, Simoneit 1984, Simoneit and Mazurek 1989, Zhu et al. 2004). Comparatively, few studies have investigated remote, rural and semi-rural environments (Alves et al. 2000, 2001, 2007, Cheng et al. 2006, Feng et al. 2007, Oliveira et al. 2007b, Pio et al. 2001a, b, Rissanen et al. 2006, Shimmo et al. 2004a, Simoneit et al. 1990) or have been performed above ocean areas. These investigations include the Mediterranean (Gogou et al. 1996, 1998, Grimalt et al. 1988, Sicre et al. 1987, Simó et al. 1991), the North Pacific (Gagosian et al. 1981, 1982, Kawamura 1995, Kawamura et al. 2003), the South Pacific (Gagosian et al. 1987, Sicre and Peltzer 2004), the Caribbean (Mayol-Bracero et al. 2001) and the Atlantic (Conte and Weber 2002, Simoneit and Elias 2000, Simoneit et al. 1977, 1991b).

\section{SPECIATION OF ORGANIC AEROSOLS}

\section{POLYCYCLIC AROMATIC HYDROCARBONS}

The polycyclic aromatic hydrocarbons (PAH) represent an organic class more investigated than any other, because they are believed to be carcinogenic and/or mutagenic (Baek et al. 1991, Brown et al. 1996, Crimmins and Baker 2006, Dyremark et al. 1995, Li et al. 2003). The carcinogenicity of PAH is about $1 / 10^{3}-1 / 10^{4}$ of that of 2,3,7,8-TCDD. The PAH concentration in the atmosphere is about $10^{4}-10^{6}$ times higher than that of TCDD. Therefore, the carcinogenic risk of PAH in the atmosphere is so high that it must be monitored as we would monitor dioxins (Okuda et al. 2006). Fossil fuel combustion is the main anthropogenic activity responsible for the introduction of PAH into the urban atmospheres. Stationary sources such as domestic heating, various industrial processes, incineration and energetic production systems are also responsible for the imprint of polyaromatics (Baek et al. 1991, Cincinelli et al. 2007, Lee et al. 2002, Liu et al. 2006, Sklorz et al. 2007). The natural sources responsible for the release of PAH comprise forest fires, microbiological processing of detritus (e.g. fossil fuel) and mechanisms of biosynthesis carried out by algae, plants and bacteria (Cincinelli et al. 2007, Smith and Harrison 1998).

Atmospheric PAH in the air (Table I) are associated both with the vapour phase and the particulate matter, being incorporated onto aerosols via condensation and adsorption processes (Lewis et al. 1995, Shimmo et al. 2002). The temporal resolution of these compounds in ambient air is limited by the detection limits of current analytical techniques. Either collecting more sample or increasing the analytical sensitivity is required to increase the detectability of PAH and nitroPAH in ambient air. Greater sampling flow rates and the corresponding larger pressure drops may increase volatilisation losses from the sampling substrate. In addition, the higher sample volumes and longer sampling times may increase the exposure of PAH and nitro-PAH to oxidants. Increasing collection surface area to increase sampler flow rates without additional pressure drops may increase both gas ab/adsorption and the potential for greater matrix contamination (Crimmins and Baker 2006). In most cases, PAH have been collected as 


\section{TABLE I}

Properties and structures of select PAH (Sources: http://chemfinder.cambridgesoft.com/; http://www.europa.eu.int/comm/environment/air/pdf/annex_pah.pdf).

\begin{tabular}{|c|c|c|c|c|c|c|c|}
\hline PAH & Formula & $\begin{array}{c}\text { Molecular } \\
\text { weight } \\
\left(\mathrm{g} \mathrm{mol}^{-1}\right)\end{array}$ & $\begin{array}{c}\text { Boiling } \\
\text { point } \\
\left({ }^{\circ} \mathrm{C}\right)\end{array}$ & $\begin{array}{c}\text { Melting } \\
\text { point } \\
\left({ }^{\circ} \mathrm{C}\right)\end{array}$ & $\begin{array}{c}\text { Vapour } \\
\text { pressure } \\
\left(\text { at } 25^{\circ} \mathrm{C}\right) \\
(\mathrm{Pa}) \\
\end{array}$ & $\begin{array}{c}\text { Water } \\
\text { solubility } \\
\left(\text { at } 25^{\circ} \mathrm{C}\right) \\
\left(\mu \mathrm{g} \mathrm{L}^{-1}\right) \\
\end{array}$ & Structure \\
\hline Naphtalene & $\mathrm{C}_{10} \mathrm{H}_{8}$ & 128 & 217.9 & 81 & 10.4 & $3.17 \mathrm{E} 4$ & \\
\hline Acenaphtilene & $\mathrm{C}_{12} \mathrm{H}_{8}$ & 152 & 295 & $92-93$ & $8.9 \mathrm{E}-1$ & $3.93 \mathrm{E} 3$ & \\
\hline Acenaphthene & $\mathrm{C}_{12} \mathrm{H}_{10}$ & 154 & 279 & 95 & $2.9 \mathrm{E}-1$ & $3.93 \mathrm{E} 3$ & \\
\hline Fluorene & $\mathrm{C}_{13} \mathrm{H}_{10}$ & 166 & 295 & $115-116$ & $8.0 \mathrm{E}-2$ & $1.98 \mathrm{E} 3$ & \\
\hline Phenanthrene & $\mathrm{C}_{14} \mathrm{H}_{10}$ & 178 & 340 & 100.5 & $1.6 \mathrm{E}-2$ & $1.29 \mathrm{E} 3$ & \\
\hline Anthracene & $\mathrm{C}_{14} \mathrm{H}_{10}$ & 178 & 342 & 216.4 & $8.9 \mathrm{E}-4$ & 73 & \\
\hline Fluoranthene & $\mathrm{C}_{16} \mathrm{H}_{10}$ & 202 & 375 & 108.8 & $1.2 \mathrm{E}-3$ & 260 & \\
\hline Pyrene & $\mathrm{C}_{16} \mathrm{H}_{10}$ & 202 & 393 & 150.4 & $6.0 \mathrm{E}-4$ & 135 & \\
\hline Benzo[a]anthracene & $\mathrm{C}_{18} \mathrm{H}_{12}$ & 228 & 400 & 160.7 & $2.8 \mathrm{E}-5$ & 14 & \\
\hline Chrysene & $\mathrm{C}_{18} \mathrm{H}_{12}$ & 228 & 448 & 253.8 & $\begin{array}{l}8.4 \mathrm{E}-5 \\
\left(20^{\circ} \mathrm{C}\right)\end{array}$ & 2.0 & \\
\hline Retene & $\mathrm{C}_{18} \mathrm{H}_{18}$ & 234 & $\begin{array}{l}390- \\
394\end{array}$ & 99 & & $\begin{array}{c}<1 \mathrm{~g} \mathrm{~L}^{-1} \\
\left(18^{\circ} \mathrm{C}\right)\end{array}$ & \\
\hline Benzo[b]fluoranthene & $\mathrm{C}_{20} \mathrm{H}_{12}$ & 252 & 481 & 168.3 & $\begin{array}{l}6.7 \mathrm{E}-5 \\
\left(20^{\circ} \mathrm{C}\right)\end{array}$ & 1.2 & \\
\hline Benzo[k]fluoranthene & $\mathrm{C}_{20} \mathrm{H}_{12}$ & 252 & 480 & 215.7 & $\begin{array}{l}1.3 \mathrm{E}-8 \\
\left(20^{\circ} \mathrm{C}\right)\end{array}$ & 0.76 & \\
\hline Benzo[a]pyrene & $\mathrm{C}_{20} \mathrm{H}_{12}$ & 252 & 496 & 178.1 & $\begin{array}{l}7.3 \mathrm{E}-7 \\
\left(20^{\circ} \mathrm{C}\right) \\
\end{array}$ & 3.8 & \\
\hline Indeno[1,2,3-cd]pyrene & $\mathrm{C}_{22} \mathrm{H}_{12}$ & 276 & 536 & 163.6 & $\begin{array}{l}1.3 \mathrm{E}-8 \\
\left(20^{\circ} \mathrm{C}\right) \\
\end{array}$ & 62 & \\
\hline Benzo[ghi]perylene & $\mathrm{C}_{22} \mathrm{H}_{12}$ & 276 & 545 & 278.3 & $1.4 \mathrm{E}-8$ & 0.26 & \\
\hline Dibenzo[a,h]anthracene & $\mathrm{C}_{24} \mathrm{H}_{14}$ & 278 & 266.6 & 524 & $\begin{array}{l}1.3 \mathrm{E}-8 \\
\left(20^{\circ} \mathrm{C}\right)\end{array}$ & $\begin{array}{c}0.5 \\
\left(27^{\circ} \mathrm{C}\right)\end{array}$ & \\
\hline Coronene & $\mathrm{C}_{24} \mathrm{H}_{12}$ & 300 & 525 & $>350$ & $2 \mathrm{E}-10$ & 0.122 & \\
\hline
\end{tabular}

particulate compounds on glass- or quartz-fibre filters by using air conventional high-volume samplers. However, as pointed out in several articles, 3- to 5-ring PAH, which have relatively high vapour pressures, are also found in the gas phase at ambient temperatures and their retention on the filter media is not complete. Thus, it has been recommended the simultaneous utilisation of trapping materials such polyurethane foam plugs or resins for sampling the gaseous fraction (Conde et al. 2004, Dimashki et al. 2000, Kavouras et al. 1999a, Knecht and Woitowitz 1988, Ligocki and Pankow 1989, Lim et al. 1999, Shimmo et al. 2002, 2004b, Zielinska et al. 2004). 
It is known that PAH undergo chemical and photochemical degradation in the atmosphere, especially in the presence of atmospheric oxidants such as ozone, hydroxyl radical and nitrate radical. These reactions continue during sampling. As a result, the PAH concentration profiles will be changed during sampling and their potential adverse health effects will be over- or underestimated (Liu et al. 2006). A possible way to reduce ozonisation reaction during sampling is the use of a denuder to remove ozone from the air stream prior to the collection of aerosol particles on the filter. Recently, some researchers have applied ozone denuders to high- and low-volume sampling to inspect their influence on the sampling of ambient PAH. Schauer et al. (2003b) made use of an activated carbon denuder in a low-volume sampler. It was found that the degradation of 5- and 6-ring PAH on filter had a near-linear dependence on ozone volume mixing ratio. According to this investigation, filter reaction artefact can lead up to a 2-fold underestimation of real atmospheric PAH levels. Tsapakis and Stephanou (2003) employed a high-volume oxidant denuder, consisting of tubes coated with water/glycerol $\mathrm{KNO}_{2}$ solution. Most of the gas and particulate phase $\mathrm{PAH}$ were vulnerable to ozone degradation under long sampling times with high $\mathrm{O}_{3}$ levels. Creutznacher et al. (2003) studied the ozone cross-sensitivity of particle accumulated $\mathrm{PAH}$, using a manganese oxide ozone denuder. In disagreement with the previous studies, the authors concluded that, for an average ozone level of $60 \mu \mathrm{g} \mathrm{m}^{-3}$, only benzo[a]pyrene had a perceptible degradation of approximately $15 \%$ in the non-denuded samples by comparing their average yearly concentrations. Liu et al. (2006) used a $\mathrm{MnO}_{2}$ ozone denuder and found that levels of 5- to 7-ring PAH were underestimated in non-denuded samples, while the 4- to 5-ring oxygenated PAH were overestimated. The highest losses due to reaction with atmospheric oxidants were observed for benzo[a]pyrene and perylene.

Extraction of PAH from their sampling media has been traditionally performed using Soxhlet or ultrasonic agitation. A more recent alternative to these two methods is the use of supercritical fluid extraction (SFE) [Friedrich and Kleiböhmer 1997, Hawthorne and Miller 1987, Lewis et al. 1995, Shimmo et al. 2002, 2004b]. Quantitative analysis is generally performed by GC or high HPLC coupled with fluorescence, UV, FID and MS detectors (Becker et al. 1999, Brown et al. 1996, Dimashi et al. 2000, Lewis et al. 1995). Some authors reported also direct analysis of PAH by thermal desorption GC/MS applied mostly to urban dust reference materials (Crimmins and Baker 2006, Falkovich and Rudich 2001, Waterman et al. 2000). OchsenkühnPetropoulou et al. (2003) presented the development of an on-line technique, the pyrolysis/GC-MS for the identification and the quantification of $\mathrm{PAH}$ in airborne particulate matter collected on cellulose filters. By this technique a pre-treatment of the samples is not necessary, avoiding the time consuming and expensive extraction step (Fabbri et al. 2002).

Since traffic, a prominent source of polynuclear hydrocarbons, present large emissions and have dramatic effects on air quality, attention has been focused on urban areas, especially in busy roads, tunnels and city centres (Tables II and III). Background concentrations of PAH reported at remote sites are 1-2 of magnitude lower (Halsall et al. 1997). Some other studies have been devoted to the identification of PAH in particular combustion sources or in the proximity of specific emissions sources: wildfires (Masclet et al. 1995, Okuda et al. 2002), charcoal grilling (Dyremark et al. 1995), biomass burning (Fine et al. 2001, 2002a, b, 2004a, Freeman and Cattell 1990, Hays et al. 2005, Keshtkar and Ashbaugh 2007, Lee et al. 2005, Oros and Simoneit 2001a, b, Rogge et al. 1998, Santos et al. 2002, Schauer et al. 2001, Sheesley et al. 2003), ferries (Cooper et al. 1996), diesel exhausts (Cho et al. 2004, Jiao and Lafleur 1997, McDonald et al. 2004, Reilly et al. 1998. Schauer et al. 1999b, Zielinska et al 2004), burning of sugar plantations (Godoi et al. 2004, Santos et al. 2002), near power plants (Kalaitzoglou et al. 2004), vegetable oil processing plant (Kavouras et al. 2001b), cooking with seed oils (Schauer et al. 2002b), incinerators (Besombes et al. 2001, Lee et al. 2002, Mao et al. 2007), burning of foliar fuels (Hays et al. 2002), roadside (Harrison et al. 2003) and vehicle exhausts for different fuels, lubricants and engine operating conditions (Brandenberger et al. 2005, Lim et al. 2005, 2007, Pedersen et al. 1980, Schauer et al. 2002c, Westerholm et al. 1988, 1992, Yang et al. 2005b, 2007, Zielinska et al. 2004).

The discovery in the 1970 s of potent mutagenic nitro-PAH in the organic extracts of atmospheric particu- 
TABLE II

Comparison of PAH concentrations obtained at road tunnels throughout the world $\left(\mathrm{ng} \mathrm{m}^{-3}\right)$.

\begin{tabular}{|c|c|c|c|c|}
\hline Compound & $\begin{array}{l}\text { Baltimore } \\
\text { USA } \\
\text { Gordon et al. } \\
\text { (1989) }\end{array}$ & $\begin{array}{c}\text { Santa Barbara } \\
\text { Brazil } \\
\text { Miguel and Pereira } \\
\text { (1989) }\end{array}$ & $\begin{array}{c}\text { Chicago } \\
\text { USA } \\
\text { Khalili et al. } \\
\text { (1995) }\end{array}$ & $\begin{array}{c}\text { Queensway } \\
\text { Birmingham, UK } \\
\text { Smith and } \\
\text { Harrison (1996) }\end{array}$ \\
\hline Fluorene & 18.0 & 96.9 & 300 & 25.6 \\
\hline Acenaphthene & 2.9 & 4.19 & 177 & 9.41 \\
\hline Anthracene & 20.0 & 69.6 & 117 & 21.1 \\
\hline Fluoranthene & 27.0 & 76.3 & 193 & 29.9 \\
\hline Pyrene & 7.6 & 51.3 & 90.2 & 11.6 \\
\hline Benz[a]anthracene & & 69.5 & 77.9 & 18.5 \\
\hline Chrysene & & 88.2 & 43.6 & 5.4 \\
\hline Benzo[b]fluoranthene & & 36.7 & 41.2 & 12.7 \\
\hline Benzo[k]fluoranthene & 5.8 & 90.7 & 62.6 & 35.2 \\
\hline Benzo[a]pyrene & 8.0 & 162.0 & 17.0 & 35.2 \\
\hline Benzo[ghi]perylene & 4.6 & 84.2 & 20.0 & 21.5 \\
\hline Indeno[1,2,3-cd]pyrene & 4.7 & & & 11.8 \\
\hline Compound & $\begin{array}{l}\text { Kurashiki, Japan } \\
\text { (north entrance) } \\
\text { Oda et al. (2001) }\end{array}$ & $\begin{array}{l}\text { Kurashiki, Japan } \\
\text { (south entrance) } \\
\text { Oda et al. (2001) }\end{array}$ & $\begin{array}{l}\text { Kurashiki, Japan } \\
\text { (centre of the } \\
\text { tunnel) } \\
\text { Oda et al. (2001) }\end{array}$ & $\begin{array}{c}\text { Rio de Janeiro } \\
\text { Azevedo et al. } \\
\text { (1999) }\end{array}$ \\
\hline \multicolumn{5}{|l|}{ Fluorene } \\
\hline Acenaphthene & & & & 2.2 \\
\hline \multicolumn{5}{|l|}{ Anthracene } \\
\hline Fluoranthene & 12 & 13 & 25 & 12.1 \\
\hline Pyrene & 18 & 20 & 25 & 18.2 \\
\hline Benz[a]anthracene & 5.4 & 6.6 & 11 & 2.1 \\
\hline \multicolumn{5}{|l|}{ Chrysene } \\
\hline Benzo[b]fluoranthene & 5.5 & 7.0 & 11 & \\
\hline Benzo[k]fluoranthene & 2.5 & 2.6 & 4.4 & \\
\hline Benzo[a]pyrene & 4.2 & 6.2 & 11 & 0.6 \\
\hline Benzo[ghi]perylene & 3.8 & 5.3 & 9.8 & 0.5 \\
\hline Indeno[1,2,3-cd]pyrene & 1.5 & 2.2 & 3.1 & \\
\hline
\end{tabular}

late matter and later in the extracts of diesel exhausts has led to a sharp increase in interest in the environmental occurrence of these compounds and in the improvement of analytical procedures for their quantification (Bamford and Baker 2003, Bamford et al. 2003, Dimashki et al. 2000). Nitro-PAH can be 100,000 times more mutagenic and 10 times more carcinogenic compared to the unsubstituted-PAH (Bamford and Baker 2003). Concentrations of the different compounds vary with the extent of urbanisation (Table IV). For example, 1-nitropyrene is normally the most abundant nitro-PAH measured in urban/industrial cities; however, in suburban and rural locations, the concentration of nitro-PAH produced from gas-phase reactions, such as 2-nitrofluoranthene, are typically higher (Bamford and Baker 2003). The nitroaromatic constituents seem to derive from a wide range of emitter sources, including combustion processes, vehicle exhausts, stationary sources, kerosene heaters, cigarette smoke and atmospheric photo-chemical reactions (Bamford and Baker 2003, Ciccioli et al. 1996, Dimashki et 
TABLE III

Comparison of PAH concentrations obtained at urban areas throughout the world $\left(\mathrm{ng} \mathrm{m}^{-3}\right)$. I - Santiago of Chile (Kavouras et al. 1999a); II - Birmingham, UK (Smith and Harrison 1996); III - Munich, Germany (Schnelle-Kreis et al. 2001); IV - Hong Kong, China (Zheng et al. 1997); V - Pavia, Italy (Minoia et al. 1997); VI - London, UK (Brown et al. 1996); VII - Portland, USA (Ligocki and Pankow 1989); VIII - Moe, Australia (Lyall et al. 1988); IX Tokyo, Japan (Okuda et al. 2000); X - Temuco, Chile (Tsapakis et al. 2002); XI - Kuala Lumpur, Malaysia (Omar et al. 2002); XII - Fuji, Japan (Ohura et al. 2004); XIII - Shimizu, Japan (Ohura et al. 2004); XIV - Lahore, Pakistan (Smith et al. 1996); XV - São Paulo, Brazil (Martinis et al. 2002); XVI - Bravo Murillo, Las Palmas de Gran Canaria, Spain (Cancio et al. 2004); XVI -industrial park in Taichung, Taiwan (Fang et al. 2004); XVII - roadside, Hong Kong (Ho et al. 2002); XVIII - Seoul, Korea (Park et al. 2002); XIX - Athens, Greece (Mandalakis et al. 2002).

\begin{tabular}{|c|c|c|c|c|c|c|c|c|c|}
\hline & Phenanthr. & Anthrac. & Fluoranth. & \multicolumn{2}{|c|}{ Pyrene } & MPhen. & $\mathrm{B}[\mathrm{a}]$ ant. & Crysene & $\mathrm{B}[\mathrm{b}] \mathrm{fl}$. \\
\hline I & $0.00-1.54$ & $0.00-0.04$ & $0.00-0.23$ & \multicolumn{2}{|c|}{$0.00-0.07$} & & $0.01-0.14$ & $0.03-0.50$ & $0.06-1.73$ \\
\hline II & $1.08 / 0.25$ & $0.39 / 0.16$ & $1.17 / 0.55$ & \multicolumn{2}{|c|}{$2.36 / 0.55$} & & $1.48 / 0.13$ & $2.21 / 0.21$ & $1.87 / 0.34$ \\
\hline III & & & $0.02-2.12$ & \multicolumn{2}{|c|}{$0.02-2.16$} & & & $0.01-2.01$ & \\
\hline IV & 1.06 & & 0.23 & \multicolumn{2}{|c|}{0.58} & & & 1.00 & \\
\hline $\mathrm{V}$ & & & & & & & $0.19 / 0.08$ & & $0.38 / 0.25$ \\
\hline VI & $24.0 / 19.5$ & $2.0 / 1.8$ & $8.0 / 19.8$ & \multicolumn{2}{|c|}{$12.0 / 17.5$} & & & $6.4 / 4.5$ & \\
\hline VII & 0.28 & & & & & $0.16-0.1$ & 1.2 & & \\
\hline VIII & & & & \multicolumn{2}{|c|}{0.072} & & & & \\
\hline IX & $27.0^{*}$ & $27.0^{*}$ & 5.2 & \multicolumn{2}{|c|}{3.1} & 13.3 & & & \\
\hline $\mathrm{X}$ & 50.6 & 6.7 & 18.9 & \multicolumn{2}{|c|}{15.5} & 12.3 & 115.7 & 163.2 & $98.5 * *$ \\
\hline $\mathrm{XI}$ & 0.32 & $<0.03$ & & \multicolumn{2}{|c|}{0.18} & 0.06 & 0.06 & 0.09 & 0.05 \\
\hline XII & $26.27 / 12.57$ & $0.42 / 0.93$ & $9.84 / 12.57$ & \multicolumn{2}{|c|}{$3.00 / 2.86$} & $2.22 / 1.35$ & $0.12 / 0.98$ & $0.41 / 1.60$ & $0.06 / 0.15$ \\
\hline XIII & $17.25 / 10.10$ & $0.32 / 0.34$ & $5.56 / 4.74$ & \multicolumn{2}{|c|}{$1.51 / 1.19$} & $0.81 / 1.69$ & $0.04 / 0.39$ & $0.11 / 0.93$ & $0.02 / 0.06$ \\
\hline XIV & 0.97 & 4.99 & 2.81 & \multicolumn{2}{|c|}{2.93} & & 5.39 & 8.64 & 9.87 \\
\hline XV & 10.9 & 1.8 & 6.9 & \multicolumn{2}{|c|}{12.2} & & 3.2 & 3.5 & \\
\hline XVI & 145.7 & 184.7 & 86.6 & \multicolumn{2}{|c|}{124.7} & & 16.9 & 37.3 & 9.1 \\
\hline XVII & 30.9 & & 7.1 & \multicolumn{2}{|c|}{6.7} & & & & \\
\hline XVIII & 16.46 & 2.7 & 8.1 & \multicolumn{2}{|c|}{12.56} & & 2.62 & 3.62 & $4.89 \#$ \\
\hline XIX & 0.46 & 0.14 & 0.15 & \multicolumn{2}{|c|}{0.19} & 0.43 & 0.11 & 0.45 & 0.86 \\
\hline & $\mathrm{B}[\mathrm{j}+\mathrm{k}] \mathrm{fl}$ & $\mathrm{B}[\mathrm{e}]$ pyr. & $\mathrm{B}[\mathrm{a}]$ & & $\mathrm{I}[1$, & 3-cd]P & $\mathrm{B}$ [ghi])Per & $\mathrm{D}[\mathrm{a}, \mathrm{h}] \mathrm{A}$ & Coron. \\
\hline I & $0.07-1.34$ & $0.03-0.86$ & 0.03 & & & $1-0.32$ & $0.10-1.32$ & & $0.05-0.66$ \\
\hline II & $1.12 / 0.14$ & & $0.73 /$ & & & $/ 0.42$ & $1.91 / 0.76$ & $0.78 / 0.07$ & $1.03 / 0.27$ \\
\hline III & $0.06-4.51$ & & 0.02 & & & & $0.02-2.75$ & & \\
\hline IV & & 0.65 & 0. & & & 32 & 0.33 & & 0.28 \\
\hline $\mathrm{V}$ & $0.18 / 0.02$ & & 0.37 & & & b.d.1. & & 0.09 & \\
\hline VI & $6.1 / 2.5$ & $7.0 / 3.2$ & 2.7 & & & $/ 1.8$ & $4.1 / 2.0$ & $0.2 / 0.1$ & $2.0 / 1.1$ \\
\hline VII & 3.6 & & & & & & & & \\
\hline VIII & 0.104 & 0.26 & 0. & & & & 0.46 & & 0.17 \\
\hline IX & 1.0 & 0.4 & 0. & & & .4 & 0.4 & & 0.20 \\
\hline $\mathrm{X}$ & $98.5^{* *}$ & 73 & 98 & & & 8.8 & 75.8 & & \\
\hline $\mathrm{XI}$ & 0.05 & 0.03 & 0.0 & & & .18 & 0.47 & 0.05 & 0.41 \\
\hline XII & $0.38 / 1.69$ & $0.32 / 1.18$ & $0.18 /$ & & & 3/1.14 & $0.29 / 1.29$ & $0.04 / 0.11$ & $0.07 / 0.46$ \\
\hline XIII & $0.12 / 0.90$ & $0.26 / 0.70$ & $0.07 /$ & & & /0.61 & $1.22 / 0.63$ & $0.01 / 0.06$ & $0.05 / 0.27$ \\
\hline XIV & 4.61 & & 9.3 & & & 2.31 & 14.64 & 3.85 & 5.40 \\
\hline $\mathrm{XV}$ & & 0.4 & 0. & & & .1 & 0.2 & & \\
\hline XVI & 12.6 & 29.1 & 9. & & & 5.2 & 6.5 & 5.6 & 22.2 \\
\hline XVII & & & 0. & & & .5 & 0.7 & 0.1 & \\
\hline XVIII & 4.89\# & & 2.5 & & & .59 & 3.21 & 0.55 & \\
\hline XIX & $* *$ & 0.35 & 0.1 & & & 45 & 0.44 & 0.08 & 4.94 \\
\hline
\end{tabular}

Note: MPhen = Methylphenanthrenes; $\mathrm{B}[\mathrm{a}]$ ant. = Benzo[a]anthracene; $\mathrm{B}[\mathrm{b}] \mathrm{fl} . \quad=$ Benzo[b]fluoranthene; $\mathrm{B}[\mathrm{j}+\mathrm{k}] \mathrm{fl}$. = Benzo[j+k]fluoranthene; $\mathrm{B}[\mathrm{e}]$ pyr. $=\mathrm{B}[\mathrm{e}]$ pyrene; $\mathrm{B}[\mathrm{a}]$ pyr. $=\mathrm{B}[\mathrm{a}]$ pyrene; $\mathrm{I}[1,2,3-\mathrm{cd}) \mathrm{P}=\mathrm{Indeno}[1,2,3-$ cd)pyrene; $\mathrm{B}[$ ghi])Per. = Benzo[ghi])perylene; $\mathrm{D}[\mathrm{a}, \mathrm{h}] \mathrm{A}=$ Dibenzo[a,h]anthracene, Coron. = Coronene; cells in white represent concentrations not determined; / = summer/winter concentrations; b.d.l. = bellow detection limit; *Phenanthrene+Anthracene; **Benzo[b+j+k]fluoranthene; \# Benzo[b+k]fluoranthene. 
al. 2000, Korfmacker et al. 1987, Perrini et al. 2005). The specific isomers of the nitro-PAH observed in ambient air suggest that they are formed in the atmosphere through the gas-phase reactions of the 2- to 4-ring PAH (Schneider et al. 1990). Thus, ambient air contains nitro$\mathrm{PAH}$ isomers distinct from the PAH electrophilic nitration products reported in direct emissions. The nitroPAH isomers not formed from electrophilic nitrations were observed, however, in laboratory simulations of the atmospheric reactions of the $\mathrm{PAH}$, providing strong evidence for atmospheric formation of nitro-PAH (Atkinson and Arey 1994). The apprehension committed to monoand dinitro-derivates of PAH is due to their ability to provoke direct mutagenic activity and to contribute for $10 \%$ to the total mutagenicity of inhalable suspended particles in polluted areas (Atkinson and Arey 1994, Marino et al. 2000). Though numerous nitro-PAH have been detected in atmospheric as well as emission particulates, nitrated pyrenes and fluoranthenes seem to be responsible of the main effect on health of humans (Marino et al. 2000).

The occurrence of 2-nitrofluoranthene and 2-nitropyrene in particulate matter collected in urban, suburban, forest and remote areas located in Europe, America, Asia and Antarctica was investigated by Ciccioli et al. (1996). The results that were obtained confirm the photochemical origin of these components by gasphase reactions with $\mathrm{OH}$ radicals and their ubiquitous occurrence in the troposphere. In addition, it was verified that to disperse photochemically produced nitro$\mathrm{PAH}$ in areas where their occurrence is somehow prevented, carbon particles can contribute to their formation by providing a suitable surface for converting $\mathrm{NO}_{2}$ into nitrous and nitric acid by reaction with water. Bamford and Baker (2003) measured 26 nitro-PAH in an urban and suburban area of Baltimore. Concentrations of nitrated compounds produced from gas-phase reactions were significantly correlated with levels of $\mathrm{NO}_{x}$. The only nitro-PAH negatively correlated with $\mathrm{NO}_{x}$ and correlated with $\mathrm{O}_{3}$ were 3-nitro- and 4-nitrophenanthrenes, suggesting a different formation mechanism. The relative contribution of gas-phase reactions and primary emission sources of nitrated aromatics were evaluated using source specific concentration ratios of nitrofluoranthene and nitropyrene: 2-NF/1-NP and 2-NF/2-NP. It was concluded that the daytime $\mathrm{OH}$-initiated reaction was the dominant gas-phase formation pathway of 2nitrofluoranthene, especially in the summer. Laser desorption ionisation time-of-flight (LDI-TOF) mass spectrometry has been used by Bezabeh et al. (1999) for the selective screening of PAH and nitro-PAH in trapped airborne particles. In addition to $\mathrm{PAH}$, the investigators selectively detected nitro-PAH, which are known to be 1-2 orders of magnitude less abundant than their analogous $\mathrm{PAH}$, in a complex environmental matrix by employing low laser powers and negative ion detection. The three detected nitro-PAH, at estimated concentration of $<100 \mathrm{pg} \mathrm{m}^{-3}$ of air $\left(<300 \mathrm{ng} \mathrm{g}^{-1}\right.$ of particulate matter), were tentatively identified as nitropyrene, nitroperylene, and nitrodibenz[a,h]anthracene. PAH with molecular masses of 300-450 Da were observed in positive ion spectra, illustrating the capability of the LDI mass spectrometry technique to examine a mass range beyond that accessible by GC/MS. The ability to examine aerosols from small air volumes $\left(0.32-0.98 \mathrm{~m}^{3}\right)$ is essential to the understanding of factors that affect aerosol composition and may be useful for identifying individual vehicles that emit greater quantities of mutagenic combustion byproducts. LDI-TOF mass spectrometry has proven to be a powerful analytical method for the screening of PAH and nitro-PAH from aerosol particulate matter and promises to support more extensive studies of toxic constituents of combustion aerosols. Hayakawa et al. (2002) measured four nitro-PAH, pyrene and benzo[a]pyrene in the downtown and in a suburban area of Kanazawa, Japan, in each season for seven years. Concentrations of these PAH and nitro-PAH were higher at the downtown sites than at the suburban site, suggesting the dilution of these compounds during the transportation from the downtown to the suburban area. The concentration ratios of nitroPAH to PAH were larger at the downtown sites than at the suburban site. Studies using UV light and sunlight showed that degradation of nitro-PAH was faster than that of PAH. Thus, the lower concentrations of nitro-PAH in the suburban sites may be due to their being photodegraded faster than PAH during the atmospheric transportation from the downtown area to the suburban area.

The partitioning of the PAH between the gaseous and particulate phase is an important factor in estimating the rate of removal processes. $\mathrm{PAH}$ are removed from the atmosphere by transformation, wet and dry depo- 
TABLE IV

Comparison of atmospheric concentrations of selected nitro-PAH $\left(\mathrm{pg} \mathrm{m}^{-3}\right)$ measured in several locations around the world. 1-NNap (1-nitronaphthalene); 9-NAnth (9-nitroanthracene); 2-NFluor (2-nitrofluoranthene); 3-NFluor (3-nitrofluoranthene); 1-Npy (1-nitropyrene); 2-Npy (2-nitropyrene); 7-NB[a]A (7-nitrobenzo[a]anthracene); 6-NCh (6-nitrochrysene).

\begin{tabular}{|c|c|c|c|c|c|c|c|c|c|}
\hline Location & Reference & 1-NNap & 9-NAnth & 2-NFluor & 3-NFluor & 1-Npy & 2-Npy & 7-NB[a]A & 6-NCh \\
\hline Baltimore, MD & Bamford and Baker (2003) & & & & & & & & \\
\hline Winter & & 59 & 64 & 60 & 0.5 & 27 & 6.5 & 23 & 0.4 \\
\hline Summer & & & 53 & 99 & 0.3 & 8.1 & 2.7 & 3.4 & 0.1 \\
\hline Fort Meade, MD & Bamford and Baker (2003) & & & & & & & & \\
\hline Winter & & 23 & 46 & 49 & 0.3 & 21 & 4.0 & 12 & 0.4 \\
\hline Summer & & & 15 & 28 & 0.3 & 1.4 & 0.8 & 0.7 & 0.3 \\
\hline Birmingham, UK (a) & Dimashki et al. (2000) & 89 & 187 & 221 & 90 & & 33 & & \\
\hline Copenhagen, Denmark (b) & Feilberg et al. (2001) & & 63 & 91 & 39 & 127 & 20 & & \\
\hline Riso, Denmark (c) & Feilberg et al. (2001) & & 30 & 60 & 32 & 30 & 8 & & \\
\hline Torrance, CA (d) & Arey et al. (1987) & & & & & & & & \\
\hline Night-time & & 2300 & 100 & 400 & & 30 & 30 & & \\
\hline Day-time & & 3000 & 50 & 300 & & 40 & 40 & & \\
\hline Houston, TX (e) & Wilson et al. (1995) & 354 & 29 & 39 & & 9.3 & & & 2.3 \\
\hline Columbus, OH (f) & Chuang et al. (1991) & & 50 & 60 & 20 & & & & \\
\hline Claremont, CA (g) & Zielinska et al. (1989) & & & 400 & 1.0 & 16 & 3 & & \\
\hline Athens, Greece (h) & Marino et al. (2000) & & & 90 & 60 & 40 & & & \\
\hline Rome, Italy (i) & Ciccioli et al. (1996) & & & 470 & & 70 & 70 & & \\
\hline Madrid, Spain (j) & Ciccioli et al. (1996) & & & 70 & 10 & 20 & & & \\
\hline Montelibretti, Italy (k) & Ciccioli et al. (1996) & & & 91 & & 13 & 16 & & \\
\hline
\end{tabular}

(a) Mean of 25 samples, Nov. 1995-Feb. 1996; (b) Mean of 20 winter-spring samples, 1996; (c) Mean of 14 samples, Feb. 1998-1999; (d) Mean of 6 samples collected $20 \mathrm{~km}$ south of Los Angeles, Jan.-Feb. 1985; (e) Mean of 19 samples measured between Aug. 1990-1991; (f) winter 1986/97; (g) Mean of 6 samples collected 30 km northeast of central Los Angeles; Sept. 1995; (h) Mean of 32 samples, Jan.-Dec. 1996; (i) Mean of 10 samples, Sept. 1991; (j) Mean of 14 samples, Oct. 1990; (k) Mean of 22 samples, Feb. 1988-Dec. 1994.

sition, and air-water exchange. The concentration and deposition levels of a PAH compound are influenced by the composition and strength of the emissions, the turbulence and the removal process type. There are two main removal mechanisms, including dry and wet deposition, in the atmosphere. Dry deposition refers to the transfer of both gaseous and particulate to a surface including soil, water, and vegetation when there is no precipitation (Tasdemir and Esen 2007). Wet deposition of airborne PAH occurs with the scavenging of particles by, and partitioning of organic vapour into, rain and snow (Sahu et al. 2004). A comparison of different methods for measuring deposition fluxes of particulate matter and PAH in the ambient air can be found in Shannigrahi et al. (2005). Besides the atmospheric loss/removal processes, the PAH air concentrations are controlled by a complex array of variables, some of which may also influence the seasonality in ambient levels. These variables include secondary sources of PAH into the atmo- sphere (i.e. possible volatilisation from soil, water, vegetation or/and urban surfaces), photochemical reactions, scavenging by vegetation, dilution/advection factors that are influenced by wind speed and direction, and mixed boundary layer height. Finally, seasonal temperature changes drive the gas to particle distribution and atmospheric reaction rates of PAH (Prevedouros et al. 2004).

The particulate phase PAH tend to distribute in combustion aerosols (such as soot particles) that dominantly distribute in the fine particle size range. On the other hand, considerable amounts of PAHs are also found in coarser particles, which consist mostly of geologic materials such as mineral particles. Thus, a sizeable amount of the PAH in the atmosphere is apparently associated with mineral particles. (Tamamura et al. 2007). PAH may be sorbed on dust particles, and transported over long distances (Fang et al. 2005). Long-range transport of PAH over hundreds to thousands of $\mathrm{km}$ has also been of concern in various locations in the world 
(Hou et al. 2006, Hung et al. 2005, Tamamura et al. 2007).

\section{Homologous Compound SERIES}

Aliphatic hydrocarbons, particularly normal alkanes, represent ubiquitous organics which are released into the atmosphere by many sources, rendering difficult the association between the levels of different compounds and their origin. Selected mass fragmentograms for $n$ alkanes can be obtained by searching $\mathrm{m} / z 85$ or 99 . Usually, the homologous compound distributions of $n$ alkanes in atmospheric aerosols range from $\mathrm{C}_{12}$ to $\mathrm{C}_{40}$. The higher molecular weights with an odd carbon number represent typical $n$-alkanes attributable to natural plant waxes (Abas and Simoneit 1996, 1997). It should be referred that the layer of the plant cuticles comprises long-chain, usually saturated aliphatic molecules with even-carbon called epicuticular waxes. The wax layer could be composed of up to 100 normal saturated hydrocarbons, grouped into at least 12 substituent classes having different functional groups (Günthardt-Goerg 1994). Epicuticular waxes form a bloom on the surface consisting of wax protrusions that are characteristic of each plant species (Rogge et al. 1993e). The epicuticular wax layer ranges from only a few nanometres to a few microns in thickness. Due to its position at the leaf surface, composition can certainly be altered by environmental factors, such as rain, wind, high temperatures and air pollutants, such as ozone (Percy et al. 1994). Plant wax lipids could be released, for example, by both a dust blasting effect on plant surfaces and wind abrasion causing sloughing of wax directly (Percy et al. 1994). The dominance of the $n-\mathrm{C}_{27}, n-\mathrm{C}_{29}$ and $n-\mathrm{C}_{31}$ homologs generally observed during summer shifted towards lower carbon numbers in the range $n-\mathrm{C}_{21}-n-\mathrm{C}_{25}$ during the colder season. Changes in the modal chain-length of $n$ alkane distributions have been attributed to differences in growing-season temperatures of the source regions ( $\mathrm{Si}$ moneit et al. 1991a). However, Schefuß et al. (2003) suggest a large influence of the regional precipitation regime on the chain-length distributions of leaf-wax lipids, in agreement with their biologic functionality as regulators of the plant moisture balance.

Linear alkanones and alkanals are a group of oxygenated compounds identified in aerosols. The distri- bution diagrams are given by the $m / z 58$ and 82 of the GC/MS analysis, respectively. The $n$-alkan-2-ones $<\mathrm{C}_{20}$ may in part be derived from anthropogenic activity (Seinfield and Pandis 1998, Simoneit et al. 1988) or from atmospheric oxidative processes (Simoneit et al. 1988). In some cases, the possible absence of alkanals of higher masses $\left(>\mathrm{C}_{20}\right)$ may reflect their reactivity to oxidation yielding alkanoic acids. Long chain $n$-alkan-2-ones are typically found in the waxy portion of the plant materials. The homologous series may range from $\mathrm{C}_{8}$ to $\mathrm{C}_{38}$. The $n$-alkanals with odd carbon number higher than 20 are of biogenic origin, whereas the lower compounds indicate oxidation of alkanes as possible precursors (Gogou et al. 1996). Aldehydes may occur in the epicuticular waxes as a result of the reaction of $\mathrm{O}_{3}$ on unsaturated hydrocarbons (Garrec 1994).

Typical distributions of $n$-alkanols range from $\mathrm{C}_{10}$ to $\mathrm{C}_{36}$. The selected mass fragmentograms for the corresponding trimethylsilyl ethers that result from the derivatisation process is plotted by searching the $\mathrm{m} / \mathrm{z}$ 75. Even-to-odd carbon number predominance is found in aerosols with a major biogenic contribution. The homologs $<\mathrm{C}_{20}$ are not found in fresh vascular plant waxes and may have a microbial origin. The homologs $>\mathrm{C}_{20}$ may derive from epicuticular vegetation (Abas and Simoneit 1996, 1997).

Fatty acids constitute another chief group of solvent-extractable compounds present in aerosol samples. They are majorly represented by $n$-alkanoic, $n$-alkenoic, dicarboxylic and oxo-carboxylic acids. The distribution patterns of then-alkanoic acids, which present $m / z 74$ and 87 key fragments (as methyl esters), range usually from $n-\mathrm{C}_{7}$ to $n-\mathrm{C}_{35}$. A pattern where the $n-\mathrm{C}_{22}-n-\mathrm{C}_{28}$ mode is predominant is characteristic of contributions from higher plant waxes. The homologs $<n-\mathrm{C}_{20}$ are probably derived from microbial sources, although these acids are ubiquitous in biota (Abas and Simoneit 1996, Simoneit et al. 1990). Other sources are cooking, grilling and food preparation, where these compounds are directly volatilised into the fumes (Rogge et al. 1991). These substances could also be attributed to microbial reworking during storage of vials that can occur even when sample conservation is done at $-20^{\circ} \mathrm{C}$ (Aceves and Grimalt 1993). In addition, the microbial lipids could also arise by the remobilisation of soil (Simoneit 
et al. 1988). Other biogenic contributors are fungi, bacteria, spores, pollen and algae (Rogge et al. 1993e). Lower molecular weights for $n$-alkanoic acids $\left(<\mathrm{C}_{18}\right)$ were found in emissions from petroleum-based sources such as gasoline- and diesel-powered vehicle exhaust or from distillate fuel oil, tire wear debris and road dust (Rogge et al. 1993a). The synthesis of $n$-fatty acids in plant leaves is practically identical to the synthesis of $n$-alkanes. These compounds proceed via elongation and descarboxylation reactions involving $\mathrm{C}_{16}$ and $\mathrm{C}_{18}$ $n$-fatty acids (Rogge et al. 1993e). Contrary to plant epicuticular wax, seeds (and seed oils, e.g. cooking oil), plant organelles, leaf cells, chloroplast and pollen contain predominantly $n-\mathrm{C}_{16}, n-\mathrm{C}_{18}$, mono-unsaturated $\left(\mathrm{C}_{n: 1}\right)$, di-unsaturated $\left(\mathrm{C}_{n: 2}\right)$ and poly-unsaturated fatty acids (Rogge et al. 1993b). It should be noted that the unsaturated fatty acids are indicators of recent biogenesis (Simoneit et al. 1988, Abas and Simoneit 1996).

Unsaturated $n$-fatty acids (alkenoic acids) are emitted to the atmosphere from microbial sources and from the processing, degradation and combustion of plant and animal constituents (Rogge et al. 1993e). Meat cooking is an important source of $n$-alkenoic acids, mainly oleic $\left(\mathrm{C}_{18: 1}\right)$ and palmitoleic acid $\left(\mathrm{C}_{16: 1}\right)$ (Rogge et al. 1991). Phytoplankton and bacteria also contain a number of unsaturated fatty acids (Rogge et al. 1993e, Simoneit et al. 2004a). Biomass burning presents, in general, as primary components palmitic $\left(\mathrm{C}_{16: 0}\right)$ and stearic $\left(\mathrm{C}_{18: 0}\right)$ acids (e.g. Oros and Simoneit 1999). Once emitted into the atmosphere, unsaturated fatty acids, which are indicators of recent biogenesis (Simoneit et al. 1991a), are likely to be attacked by free radicals, ozone and other oxidants, producing aldehydes, lower weight carboxylic acids and dicarboxylic acids (Rogge et al. 1993e). One method that has been used to gauge the age of aerosol is to take the ratio between the concentrations of the saturated $\mathrm{C}_{18}$ alkanoic acid $\left(\mathrm{C}_{18: 0}\right)$ and the mono-unsaturated $\mathrm{C}_{18}$ acid $\left(\mathrm{C}_{18: 1}\right)$. This ratio is used as an aerosol age indicator since the mono-unsaturated acid breaks down much faster by atmospheric oxidation than the saturated analogue. The abundance of the saturated acid compared to the mono-unsaturated homologue can, therefore, indicate a relative decomposition rate (Brown et al. 2002). Values between 5 and 11, with an average of 6.6 , for the $\mathrm{C}_{18: 0} / \mathrm{C}_{18: 1}$ ratio were reported for rural samples collected in remote Big Bend National Park, Texas. These high, rural-like ratios were ascribed to a combination of local rural biogenic emissions and aged aerosol advected from urban areas (Brown et al. 2002). While stearic and palmitic acids are, as individual compounds, not source specific, the $\mathrm{C}_{18: 0} / \mathrm{C}_{16: 0}$ fatty acid ratio is unique and can be used in source apportionment studies. The major contributors for particulate matter have $\mathrm{C}_{18: 0} / \mathrm{C}_{16: 0}$ ratios ranging from 0.17 to 0.71 , depending on source type. In countries where dried cattle dung is used for cooking purposes, fine particulate smoke presents the characteristically elevated ratio around 2, whereas for foliar vegetation or wood smoke and car exhaust, values below 0.5 are typical. The surface soil and dusts from feedlots and open lot dairy farms showed an average $\mathrm{C}_{18: 0} / \mathrm{C}_{16: 0}$ ratio of 3.0. Values between 0.5 and 1 were also found in agricultural fields, dust from paved and unpaved roads and in $\mathrm{PM}_{2.5}$ of rural and urban sources, such as hamburger charbroiling (Rogge et al. 2006 and references therein).

A series of alkanedioic acids is frequently present in atmospheric aerosol samples. These compounds could be oxidation products from biopolymers or other lipid components (e.g. hydroxyalkanoic acids), or incomplete combustion products (Abas and Simoneit 1996). Thus, they could represent secondary organic compounds formed by photochemical reactions. Oxocarboxylic acids are likely photo-oxidation products from cyclic olefins and unsaturated fatty acids also detected in aerosol samples. As examples, we have the $\mathrm{C}_{5}$ and $\mathrm{C}_{6}$ homologs, produced by oxidation of anthropogenic cyclic olefins, and the $\mathrm{C}_{8}$ and $\mathrm{C}_{9}$ compounds which are formed by photo-oxidation of unsaturated carboxylic acids such as the oleic $\left(\mathrm{C}_{18: 1}\right)$ and linoleic $\left(\mathrm{C}_{18: 2}\right)$ acids (Gogou et al. 1996). Products like 9-oxononanoic acid and nonanoic acid, both detected in the aerosol samples, form the final reaction products of the oleic acid with ozone (Rogge et al. 1993e). Aliphatic dicarboxylic, acids found in the particulate matter are an important compound class due to their possible formation by chemical reaction in the atmosphere (Grosjean and Seinfeld 1989, Rogge et al. 1993e). Kawamura and Kaplan (1987) found that butenedioic related acids (methyl maleic, succinic, and malic acid) are the most frequent particulate dicarboxylic acids with origin in combus- 
tion engines. Rogge et al. (1991) reported meat cooking as an emission source of $\mathrm{C}_{4}-\mathrm{C}_{8}$ dicarboxylic acids, pointing out the importance of adipic acid (hexanedioic). Pereira et al. (1982) identified dicarboxylic acids ranging from $\mathrm{C}_{4}$ to $\mathrm{C}_{9}$ in airborne ash resulting from pyrolysis of organic soil constituents, plants and trees. Acids in the range $\mathrm{C}_{10}-\mathrm{C}_{24}$ have been stressed by Simoneit and Mazurek (1982) as possible oxidation products of hydroxy acids from vegetation.

Table V presents the levels of the homologous compound series in atmospheric aerosols from different environments all over the world. Fatty acids and $n$-alkanes, followed by $n-$, are the dominant organic classes. The homologous compounds associated with fossil fuel and biomass burning may be up to 30 times more abundant in winter that in summer due to stronger emissions during the cold season (Wang et al. 2006b). The increase in concentrations during winter could also be related to the fact that lower winter temperatures promote the decrease of mixing heights and the existence of inversion layers, leading to poorer dispersion and diminishing the dilution factors and, therefore, conducting to an increase of atmospheric pollutant concentrations. On the other hand, as some compounds have a highly temperature dependent gas/particle partitioning coefficient, the high summer temperature could promote their displacement from particulate to gas phase, decreasing their aerosol phase concentrations (Oliveira et al. 2007a). In China, concentrations of the homologous organic classes are generally 1-3 orders of magnitude higher than in developed countries (Wang et al. 2006b). The levels measured in the background marine atmosphere over the north Atlantic are lower than those measured in the Mediterranean and of the same order as those reported for the remote Chichi-Jima Island in the western Pacific. In contrast, the concentrations are higher than those registered in the aerosol of Enewetak Atoll, north Pacific. Hydrocarbon concentrations ranging from 30 to $2800 \mathrm{ng} \mathrm{m}^{-3}$ were found by Simoneit et al. (1991b) over the south Atlantic. The highest values were observed when approaching part of Tierra del Fuego, where extensive petroleum production occurred. The high $n$-alkane concentrations $\left(0.3-680 \mathrm{ng} \mathrm{m}^{-3}\right)$ found by Simoneit and Elias (2000) in samples of particulate matter from the atmosphere over the Atlantic along the South American and African continents were associated to epicuticular wax components of continental vegetation, which are introduced into the aerosols mainly by direct emission due to abrasive and related processes. However, long-range transport of smoke from biomass burning off the continents was also found an important factor influencing the composition of marine aerosols (Alves et al. 2007).

\section{MOLECULAR MARKERS}

The assessment of natural versus anthropogenic contributions to the carbonaceous aerosol is often done by searching molecular markers or tracers, which include organic compounds that are source specific, react slowly in the atmosphere and do not change to gas-phase during the transport. Numerous compounds were identified and quantified in the atmospheric samples, including cigarette smoke components, vehicle exhaust markers, meat smoke tracers, combustion products of plastics, coal burning emissions, phytosterols of higher photosynthetic plants and wood smoke constituents (Table VI).

\section{Tobacco smoke}

It has been pointed out that the major tracers for tobacco smoke in the urban atmosphere are 2-methyl- (iso-) and 3-methylalkanes (anteiso-alkanes) ranging from $\mathrm{C}_{29}$ to $\mathrm{C}_{34}$ (Kavouras et al. 1998a, Morrical and Zenobi 2002, Rogge et al. 1994). Their mass spectra contain the typical fragmentation pattern $\left(\mathrm{M}^{\bullet+}-\left[\mathrm{C}_{3} \mathrm{H}_{7}^{\bullet}\right], m / z\right.$ 393) for the branched alkanes. Results from the analysis of environmental tobacco smoke showed that several unique peaks are present in the mass spectrum when compared to other combustion sources, such as automobiles and diesel trucks (Table VII). In particular, ions at $m / z 118$, 132,146 , and 160 are consistently present and are not found in other combustion sources (Morrical and Zenobi 2002). Other researchers have chosen compounds such as nicotine (LaKind et al. 1999, Leaderer and Hammond 1991) and solanesol (LaKind et al. 1999, Tang et al. 1990) as markers for tobacco smoke. Nicotine and solanesol are both specific to environmental tobacco smoke and may be appropriate for the indoor environment where their reactivity may be slower, but have been shown not to be very suitable for the outdoor environment due to a high rate of reaction (Morrical and Zenobi 2002). Using isoand anteiso-alkanes, with nicotine as a confirming tracer, ambient fine cigarette smoke particles were estimated 


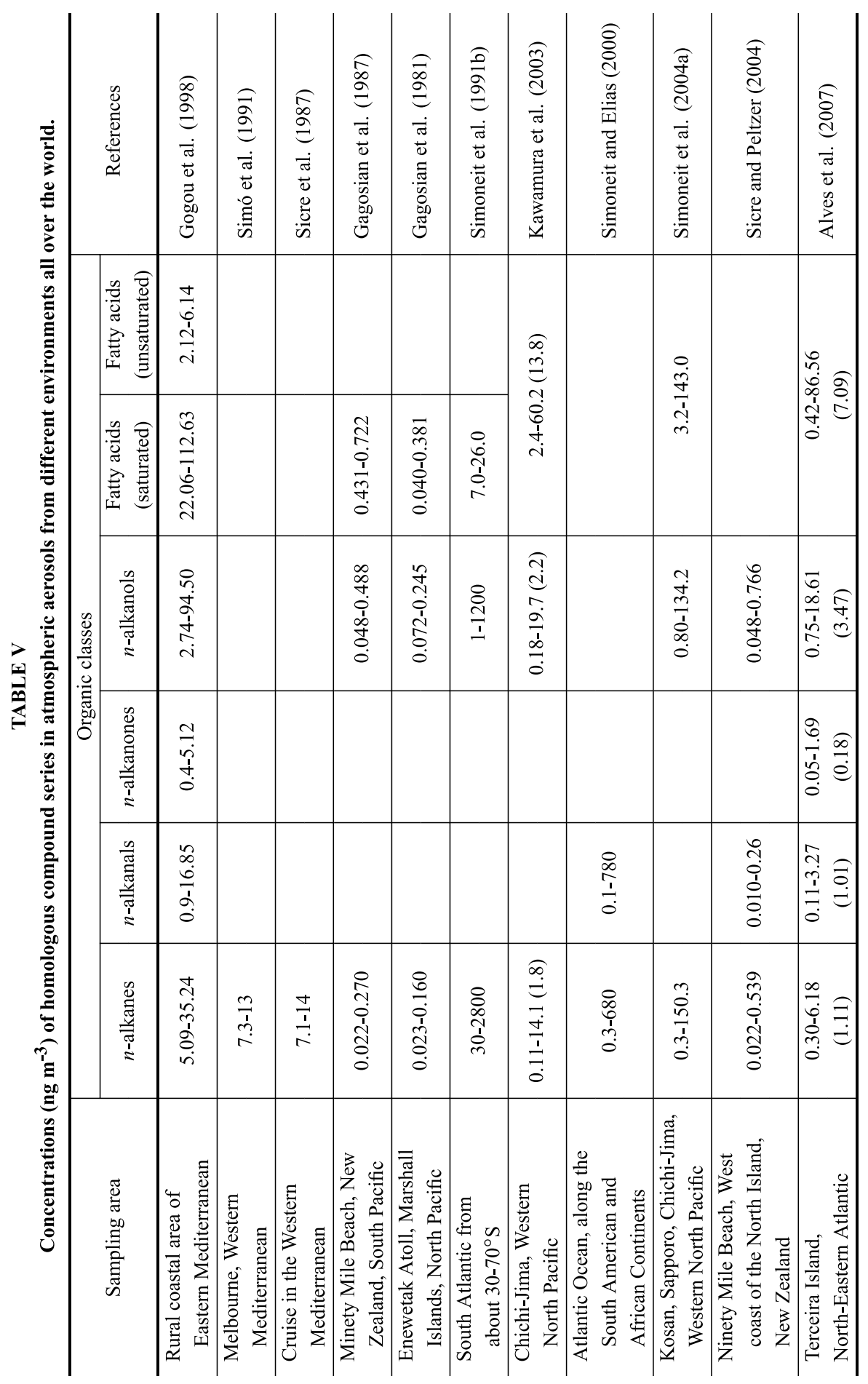




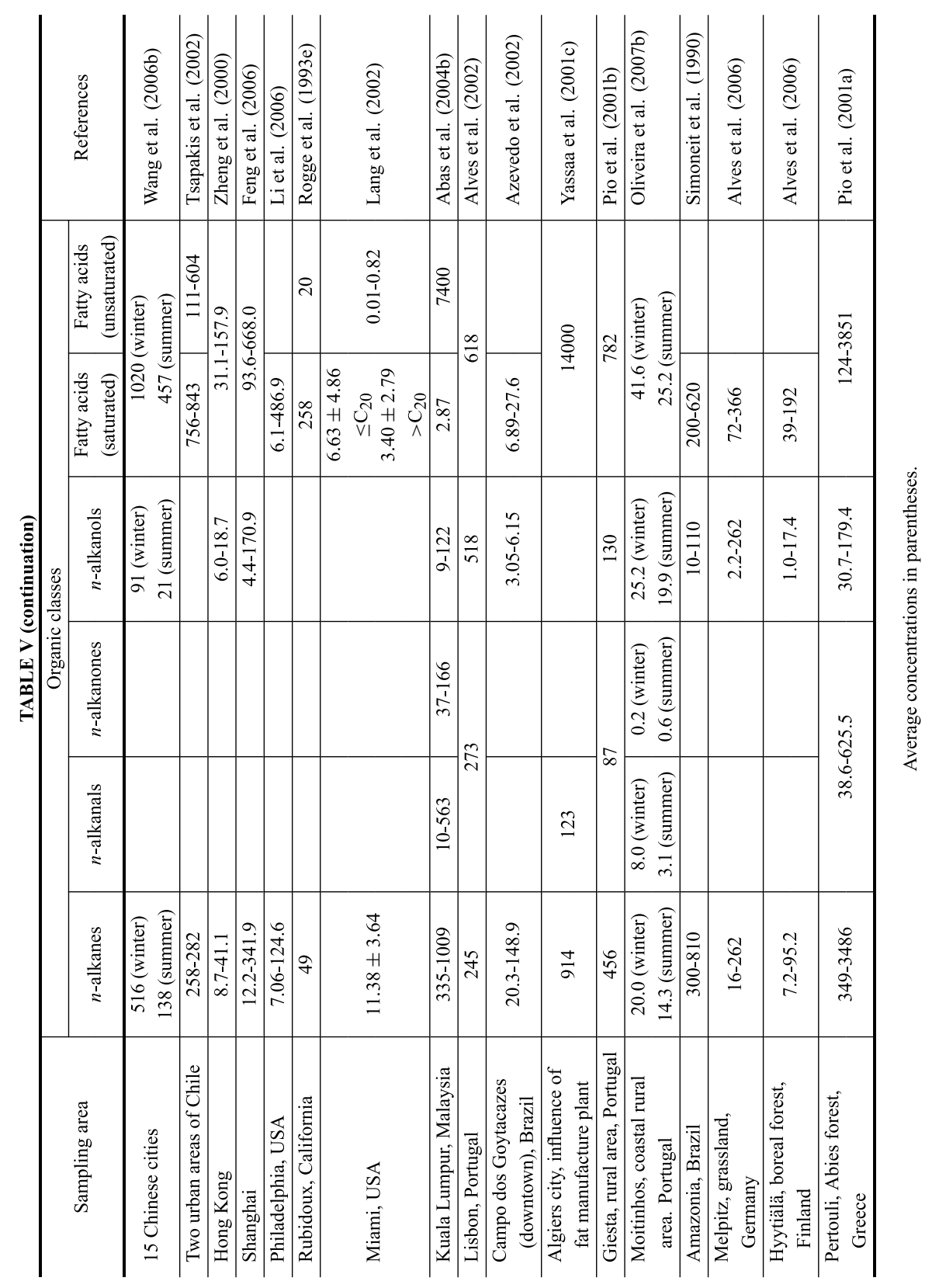


TABLE VI

Specific tracers for organic components in atmospheric aerosols.

\begin{tabular}{|c|c|c|}
\hline Compounds & Major source & Emission process \\
\hline$n$-Alkanes, $\mathrm{C}_{15}-\mathrm{C}_{20}$ (odd/even) & Microbial & Direct/resuspension \\
\hline $\mathrm{C}_{20}-\mathrm{C}_{37}$ (odd/even) & Plant waxes & Direct/biomass burning \\
\hline $\mathrm{C}_{15}-\mathrm{C}_{37}(\mathrm{CPI}=1)$ & Vehicles & Exhaust \\
\hline $\mathrm{C}_{16}-\mathrm{C}_{40+}$ (even predomin.) & Plastics & Directly volatilised during open burning \\
\hline$n$-Alkenes, $\mathrm{C}_{15}-\mathrm{C}_{37}$ & Biomass/coal & Combustion \\
\hline $\begin{array}{l}\text { Isoprenoid hydrocarbons } \\
\text { (pristane, phytane) }\end{array}$ & $\begin{array}{l}\text { Ubiquitous/ } \\
\text { not in gasoline }\end{array}$ & Exhaust \\
\hline $\begin{array}{l}\text { Triterpenoid hydrocarbons } \\
\text { (steranes and diasteranes), } \\
\mathrm{C}_{27}-\mathrm{C}_{35}\end{array}$ & $\begin{array}{l}\text { Ubiquitous/ } \\
\text { not in gasoline and } \\
\text { diesel fuels }\end{array}$ & $\begin{array}{l}\text { Lubricants of vehicular engines } \\
\text { exhaust }\end{array}$ \\
\hline Alkylcyclohexanes, $\mathrm{C}_{16}-\mathrm{C}_{29}$ & Urban aerosols & Auto exhaust \\
\hline$n$-Alkanones, $\mathrm{C}_{15}-\mathrm{C}_{35}$ & Biomass/coal & Biodegradation/combustion \\
\hline$n$-Alkanals, $\mathrm{C}_{15}-\mathrm{C}_{35}$ & Biomass/coal & Biodegration/combustion \\
\hline$n$-Alkanoic acids, $\mathrm{C}_{15}-\mathrm{C}_{37}$ & Microbial/biomass & Direct/resuspension/combustion \\
\hline $\mathrm{C}_{20}-\mathrm{C}_{36}$ & Higher plants & Direct/combustion \\
\hline$n$-Alkanoic acid salts, $\mathrm{C}_{15}-\mathrm{C}_{20}$ & Marine biomass & Sea slick resuspension \\
\hline$n$-Alkanols, $\mathrm{C}_{14}-\mathrm{C}_{36}$ & Biomass & Direct \\
\hline$n$-Alkanedioic acids, $\mathrm{C}_{6}-\mathrm{C}_{28}$ & Various & Photo-oxidation/combustion \\
\hline Wax esters & Plant waxes & Biomass combustion/direct \\
\hline Triterpenyl alkanoates & Vegetation & Biomass combustion \\
\hline Triacylglycerides & Flora/fauna & Biomass combustion/cooking \\
\hline Methoxyphenols & Biomass with lignins & Combustion \\
\hline Levoglucosan & Biomass with cellulose & Combustion \\
\hline Galactosan & Biomass with cellulose & Combustion \\
\hline Mannosan & Biomass with cellulose & Combustion \\
\hline Cholesterol & Meat/algae & Cooking/direct \\
\hline Mono- and diglycerides & Meat & Cooking/direct \\
\hline Phytosterols & Higher plants & Combustion/direct \\
\hline Triterpenoids & Higher plants & Combustion/direct \\
\hline Diterpenoids (resin acids) & Higher plants (gymnosperms) & Combustion/direct \\
\hline Hopanes/steranes & Petroleum & Vehicle exhaust and others \\
\hline $\mathrm{UCM}$ & Petroleum & Vehicle exhaust and others \\
\hline Alkylpicenes/alkylchrysenes & Coal & Combustion/heating \\
\hline Plasticisers/Antioxidants & Plastics & $\begin{array}{l}\text { Volatilised by steam stripping } \\
\text { during open burning }\end{array}$ \\
\hline
\end{tabular}

to be present at a concentration of $0.28-0.36 \mu \mathrm{g} \mathrm{m}^{-3}$ in the Los Angeles outdoor air, accounting for $1.0-1.3 \%$ of the fine particle mass concentration (Rogge et al. 1994).

\section{Vehicle emission markers}

Petroleum molecular markers are specific indicator compounds mainly present in the hydrocarbon fractions.
These kind of tracers may include the $17 \alpha(\mathrm{H}), 21 \beta(\mathrm{H})$ hopane series, the $5 \alpha(\mathrm{H}), 14 \alpha(\mathrm{H}), 17 \alpha(\mathrm{H})$ and $5 \alpha(\mathrm{H})$,$14 \beta(\mathrm{H}), 17 \beta(\mathrm{H})$-sterane series, alkylcycloalkanes, the isoprenoids pristane and phytane, as well as the chromatographic unresolved complex mixture (Gogou et al. 1996, Simoneit 1984, 1999, Simoneit et al. 1991a).

The presence of steranes $(\mathrm{m} / \mathrm{z} 217)$, diasteranes $(m / z 218)$ and hopane triterpenoids $(m / z 191)$ indicates 
TABLE VII

Cigarette specif tracers.

\begin{tabular}{|c|c|}
\hline $\begin{array}{c}\text { Mass/Charge } \\
(\mathrm{m} / \mathrm{z})\end{array}$ & Possible identities of ions at given $\mathrm{m} / \mathrm{z}$ \\
\hline 118 & indazole, benzimidazole, myosmine $\mathrm{M}-\mathrm{C}_{2} \mathrm{H}_{4}^{+}$fragment, indane \\
\hline 132 & $\begin{array}{l}\mathrm{C}_{1} \text {-alkylindazole, } \mathrm{C}_{1} \text {-alkylbenzimidazole, } \\
\text { mysomine } \mathrm{M}-\mathrm{CH}_{2}^{+} \text {fragment, } \mathrm{C}_{1} \text {-alkylindane }\end{array}$ \\
\hline 146 & $\begin{array}{l}\mathrm{C}_{2} \text {-alkylindazole, } \mathrm{C}_{2} \text {-alkylbenzimidazole, } \\
\text { mysomine, } \mathrm{C}_{2} \text {-alkylindane }\end{array}$ \\
\hline 160 & $\mathrm{C}_{3}$-alkylindazole, $\mathrm{C}_{3}$-alkylbenzimidazole, $\mathrm{C}_{3}$-alkylindane \\
\hline
\end{tabular}

petroleum residue contamination (Simoneit 1984, Simoneit et al. 1991a). Generally, the distribution patterns of petroleum biomarkers show that the $17 \alpha(\mathrm{H}), 21 \beta(\mathrm{H})$ hopane series is the predominant group, ranging from $\mathrm{C}_{27}$ to $\mathrm{C}_{35}$ with the homologs $>\mathrm{C}_{29}$ present as the typically mature C-22 R/S pairs (Simoneit et al. 1990). Distributions showing concentrations of the $22 \mathrm{~S}$ hopanes higher than those for the corresponding 22R pairs are commonly found in aerosols emitted by gasoline and diesel engines. Biogenic precursors contain only the 22R configuration (Zheng et al. 1997). Steranes are introduced into the atmosphere from lubricants of vehicular engines, but they are not found in gasoline or diesel fuel (Abas and Simoneit 1996).

Paraffinic components of petroleum, alkylcycloalkanes, could be identified in the particulate matter, by searching $m / z$ 82 and $m / z$ 68-69 typical masses, respectively, for alkylcyclohexanes and alkylcyclopentanes. Vehicular traffic with the associated fuels and lubricants emit these compounds into the ambient atmosphere. The presence of unsaturated hydrocarbons like pristane (2,6,10,14-tetramethylpentadecane) and phytane (2,6,10,14-tetramethylhexadecane) is consistent with fossil fuel sources of carbon in the range of $\mathrm{C}_{16}-\mathrm{C}_{20}$, which is approximately the distillation range of diesel fuels (Abas and Simoneit 1996, Aceves and Grimalt 1992, Azevedo et al. 2002, Fraser et al. 1997, Rogge et al. 1997a, Zheng et al. 1997). Pristane and phytane result from the diagenesis of phytol and are not primary components of the majority of terrestrial living organisms (Simoneit 1984). Biogenic inputs are often dominated by a predominance of the odd carbon alkanes and the $\mathrm{C}_{17}$ isoprenoid (pristane). Since phytane is rarely found in biological material (except some bacteria), most biological hydrocar- bons have a $\mathrm{Pr} / \mathrm{Ph}$ ratio $>>1.0$. Low $\mathrm{Pr} / \mathrm{Ph}$ ratios indicate a hydrocarbon signature derived from petrochemical use. It should be noted, however, that the identification of compounds such as pristane and phytane in atmospheric samples are dependent on the sampling period. Simoneit et al. (2004a) referred to the volatile compound blow-off from the filters over a 1-2-day acquisition time and the consequent depletion of aliphatics $<\mathrm{C}_{21}$, and therefore of the petroleum tracers.

Generally, chromatograms from the aliphatic fraction show a hump that is constituted by branched and cyclic unresolved hydrocarbons, expressing the existence of microbial or petroleum derived contaminants, especially naphthenes (Bi et al. 2002, Simoneit 1984). This UCM (unresolved complex mixture) may be plotted by searching the $m / z 95$ fragmentogram. In general, samples show a bimodal pattern, with a minor maximum at $<\mathrm{C}_{20}$ and a major one at the $\mathrm{C}_{26}$ or $\mathrm{C}_{28}$ naphthene. The first mode may indicate a source input typical of biodegraded detritus from algae and other microorganisms, which could arise by remobilisation of soil dust or from a recycled component of hydrocarbons eroded from sedimentary outcrops (Simoneit et al. 1991a). The hump observed in contaminated aerosols correlate with vehicular emissions. Auto exhaust exhibits a narrow hump maximising at $\mathrm{C}_{26}$ or at the neighbour naphthenic hydrocarbons (Simoneit 1984). The ratio of unresolved to resolved hydrocarbon components (U:R) is a parameter used to assess the magnitude of petroleum contributions to atmospheric aerosols (Tang et al. 2006). The hump: $n$-alkane ratios are determined from the gas chromatogram by the area of unresolved material above the background (measured by planimetry or integration) divided by the sum of the GC area of resolved $n$-alkanes 
and other major components (Azevedo et al. 1999). U:R values for rural, mixed and urban samples are 0.2-4, 1.4-3.4 and 0.9-25, respectively (Azevedo et al. 2002). An $U: R$ value $>>1$ indicates considerable contributions from petroleum combustion sources; pure hydrocarbon mixtures from plant waxes have $\mathrm{U}: \mathrm{R}<0.1$, i.e. they have no UCM. Generally, urban aerosols contain the largest component of petroleum-derived compounds, while rural and mixed rural/urban environments show variable contributions of anthropogenic pollutants. The average $\mathrm{U}: \mathrm{R}$ ratio for conifer smoke (1.0) suggests that the UCM of rural aerosol particles from the western United States consists mainly of recent (immature) organic matter derived from conifer and perhaps other biomass combustion source emissions, such as grass smoke released from agricultural field burning, and less pronounced fossil fuel combustion emissions (Oros and Simoneit 2001a). Several U:R ratios have been determined from more mature fossil fuel derived combustion emission sources which include the following: lignite coal $=3.2$ and bituminous coal $=3.3$ (Oros and Simoneit 2000); catalystequipped automobile engine exhaust $=5.5$ and heavyduty diesel truck engine exhaust $=9.3$ (Rogge et al. 1993d). Thus, the lower U:R ratio of conifer smoke shows that this parameter is useful for distinguishing between conifer biomass burning and fossil fuel derived combustion source emissions. Ultimately, the U:R ratio may be used as an indicator for identifying atmospheric transport trajectories from regional biomass burning and fossil fuel combustion emission containing air parcels. This is especially useful for determining the contributions of organic matter derived from rural versus urban emission sources (Oros and Simoneit 2001a).

\section{Meat smoke}

During the cooking process, triglycerides from the fat can be hydrolysed or thermally oxidised, producing free glycerol, mono- and diglycerides and free fatty acids (Nolte et al. 1999). The emission rates of these compounds can be found in Schauer et al. (1999a) and Nolte et al. (1999). Meat cooking operations were considered to be a major source of organic aerosol emissions to the urban atmosphere, comprising up to $21 \%$ of the primary fine organic carbon particle emissions in the Los Angeles area (Rogge et al. 1991). Promi- nent among the compounds emitted are $n$-hexadecanoic acid (i.e., palmitic acid), $n$-octadecanoic acid (i.e., stearic acid), cis-9-octadecenoic acid (i.e., oleic acid), nonanal, 2-octadecanal, 2-octadecanol, saturated monoglycerides and cholesterol. However, the majority of these compounds, and especially fatty acids, are emitted from so many sources in addition to meat smoke that data on their concentration alone is insufficient to determine the quantity of meat smoke aerosol in ambient air (Nolte et al. 1999). The presence of cholesterol in oceanic aerosols more likely indicates an input from marine sources such as algae, which also can contribute to continental cholesterol sources in environments downwind from lacustrine areas (Simoneit and Elias 2001). The presence of cholesterol in particles has been associated with sea spray deriving from secretions of aquatic organisms (Alves et al. 2007, Fine et al. 2004b). The sea spray explanation is supported by the occurrence of cholesterol predominantly in the larger particles (Fine et al. 2004b).

The $\mathrm{C}_{16}$ monoglycerides, 1-palmitin and 2-palmitin, dominate in meat smoke aerosols, but there are also significant emissions of $\mathrm{C}_{18}$ (1-stearin) and $\mathrm{C}_{18: 1}$ (1olein) monoglycerides (Nolte et al. 1999). Although cholesterol can be emitted from other sources, concentrations measured in the West Los Angeles atmospheric aerosol were consistent with the cholesterol mass emission rates calculated from meat cooking source tests. Thus, a group of compounds (Fig. 2), instead a single tracer, was considered to be more useful as an indicator of the quantity of meat smoke in the atmosphere. Of this assemblage, cholesterol seems to be most suitable, complemented by monoglycerides and perhaps oleic acid in the exact proportionalities (Nolte et al. 1999, Robinson et al. 2006b).

\section{Tracers for the open burning of plastics}

One way in which waste plastics impact the environment is through combustion, whether on purpose or not. Some discarding practices comprise intentional burning of waste, including plastics and plastic bags. In other occasions, wind-blown plastic litter collects in clumps and is burnt in wildfires. Anyway, smoke particles and combustion products, some of which are noxious to humans, are released into the atmosphere. In a recent investigation specific tracer compounds generated during 


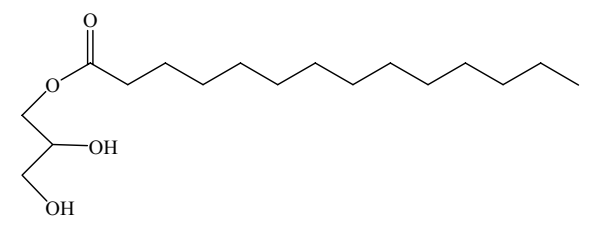

1-myristin
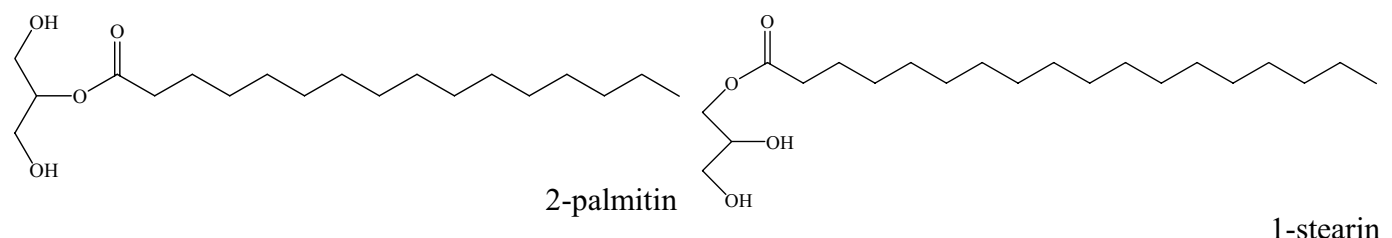

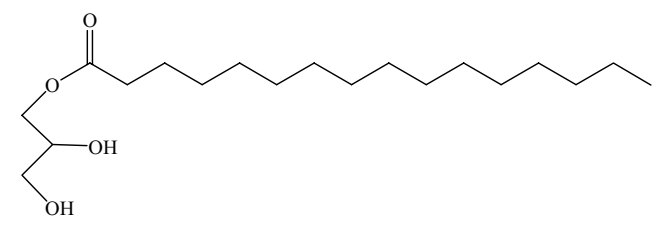

1-palmitin

1-stearin

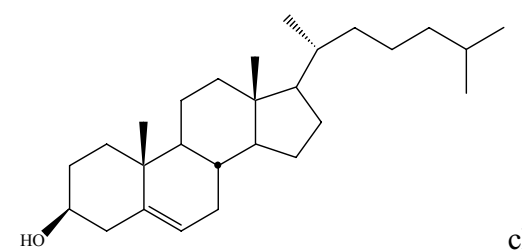

cholesterol

Fig. 2 - Chemical structures of constituents detected in meat smoke.

the open-fire combustion of plastics that can be used to detect episodes of plastic refuse burning were studied (Simoneit et al. 2005). Plastics consisting above all, but not entirely, of polyethylene plastic bags, were handpicked from the roadside and landfills, and analysed in two ways. The amounts of extractable compounds in the hexane extracts and smoke particles were 29-43 and 5.4-17.5 $\mathrm{mg} \mathrm{g}^{-1}$ of plastic, respectively. The most important compounds extracted from the plastics were plasticisers, antioxidants and $n$-alkanes with an even carbon number $\left(\mathrm{C}_{16}-\mathrm{C}_{40}\right)$, derived from the polymerisation of ethylene. Dialkyl esters of benzene-dicarboxylic acids (phthalates) are representative of plasticisers, which are widespread in the environment. The principal plasticiser was bis(2-ethylhexyl) phthalate (DEHP), a probable human carcinogen, with minor amounts of other phthalates, which are also suspected health risks (Fig. 3). In the smoke particles, the main compounds found were terephthalic acid, 4-hydroxybenzoic acid, and the phthalates. n-Alkanes were found once more, but with no carbon number predominance, indicating incomplete combustion and thermal cracking of polyethylene. The researchers proposed the minor components 1,3,5-tri- phenylbenzene (TPB) and tris(2,4-di-tert-butylphenyl) phosphate (TDPP) as candidate marker compounds because it was considered that they are not usually detected in the atmosphere. This hypothesis was confirmed by matching up to aerosol particulate matter from regions where plastic and refuse are burnt in open fires (Santiago, Chile; Saporo, Japan; Gosan Island, Korea) with that from areas supposed to be clean (Los Angeles, CA; Corvallis, OR). Both TPB and TDPP were found in the locations where open-fire burning of plastics is frequent, but were lacking from the areas apparently uncontaminated. Santiago presented the highest plastic marker content (613-6920 $\mathrm{ng} \mathrm{m}^{-3}$ of DEHP; 7-132 $\mathrm{ng} \mathrm{m}^{-3}$ of Irganox 1076), which is in agreement with the greater occurrence of garbage, litter and plastic-related combustion compared with the other cities. The plastic tracers were undetectable or present at much lower levels than those of Chile in the particulate matter from the other places.

Very high levels of phthalates (up to $2200 \mathrm{ng} \mathrm{m}^{-3}$ ) dominated by DEHP, dibutyl and diisobutyl phthalates were also detected in the aerosol from 15 Chinese cities, especially in summer, possibly due to an enhanced evap- 


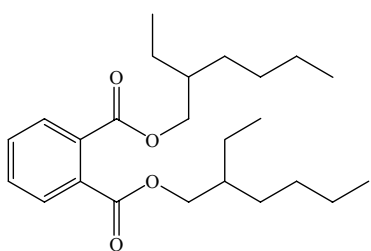

Diethylhexyl phthalate $\left(\mathrm{C}_{24} \mathrm{H}_{38} \mathrm{O}_{4}\right)$

$\mathrm{M}^{*} 390(0.5), m / z 279(17), 167(39), 150(12), 149(100), 113(9), 71(17), 57(24)$

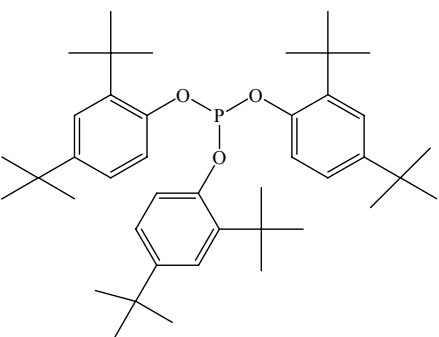

tris(2,4-di-tert-butylphenyl)phosphite

Irgafos $168\left(\mathrm{C}_{42} \mathrm{H}_{63} \mathrm{O}_{3} \mathrm{P}\right)$

$\mathrm{M}^{*+} 646, \mathrm{~m} / \mathrm{z} 441,308,191,147,57$<smiles>c1ccc(-c2cc(-c3ccccc3)cc(-c3ccccc3)c2)cc1</smiles>

1,3,5-Triphenylbenzene $\left(\mathrm{C}_{24} \mathrm{H}_{18}\right)$

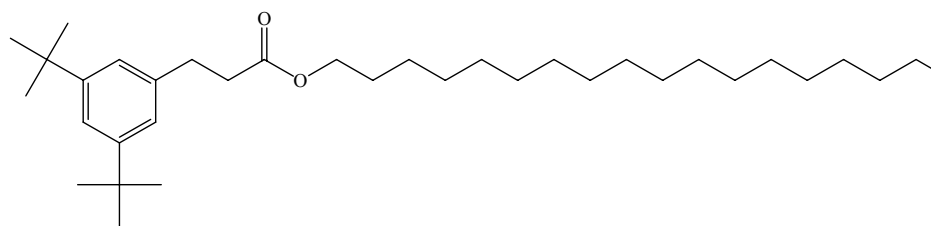

Octadecyl 3-(3,5 -di-tert-butyl-4 -hydroxyphenyl)propionate

Irganox $1076\left(\mathrm{C}_{35} \mathrm{H}_{62} \mathrm{O}_{3}\right)$

$\mathrm{M}^{*+} 530, m / z 515,219,57$

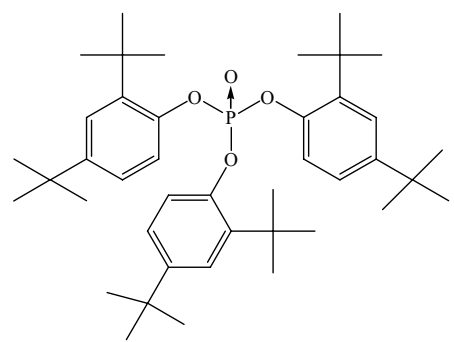

tris(2,4-di-tert-butylphenyl)phosphate $\left(\mathrm{C}_{42} \mathrm{H}_{63} \mathrm{O}_{4} \mathrm{P}\right)$

$\mathrm{M}^{*+} 662, m / z 647,308,316,191,57$

$\mathrm{M}^{\bullet+} 306, m / z 289$

Fig. 3 - Chemical structures of organic tracers in smoke from burning plastics and characteristic mass spectra. For the dominant plasticiser, ions are listed as $m / z$ with relative intensities following in parentheses.

orative realise from plastics, followed by adsorptive deposition on pre-existing particles (Wang et al. 2006b). Phthalate levels in China are 1-3 orders of magnitude higher than those in the Swedish (Thuren and Larsson 1990), Belgian (Kubátová et al. 2002) and French (Teil et al. 2006) atmospheres. Taking into account their ubiquitous and abundant occurrences, as well their carcinogenic and endocrine-disrupting characteristics, the determination of plasticiser markers in atmospheric environments will be helpful in measuring the degree of plastic burning and will assist in establishing air pollution control programs.

\section{Tracers in coal smoke}

The burning of coal to produce electricity contributes significantly to the emission of fine particulate matter into the atmosphere. The sort and loads of organic components in coal smoke particulate matter depend on combustion temperature, aeration, burn time and geologic maturity, i.e. coal rank (Oros and Simoneit 2000). The maturity of the fuel may be evaluated indirectly by determining some indicators in smoke. It is registered a decrease in carbon preference index values (see section 6) of $n$-alkanoic acids, UCM and phenolic compounds 
and an increase in the homohopane index $[\mathrm{S} /(\mathrm{S}+\mathrm{R})]$ with increasing rank. In general, the U/R and the $17 \alpha(\mathrm{H})$,$21 \beta(\mathrm{H})$-hopane to $22 \mathrm{R}-17 \alpha(\mathrm{H}), 21 \beta(\mathrm{H})$-homohopane ratios characteristic of coal smoke are in the range 2.93.3 and $0.05-0.35$, respectively. The generic markers for coal smoke emissions comprise a series of $\mathrm{C}_{27}$ to $\mathrm{C}_{31}$ hopanes (no $\mathrm{C}_{28}$ ), phenolics, $\mathrm{C}_{2}$-picenes and $\mathrm{C}_{2}$ hydropicenes (Oros and Simoneit 2000). The source specific markers are listed in Table VIII.

\section{Tracers for wood burning, vegetation and other natural inputs}

Most of the tracer molecules from vegetation are phytosterols and terpenoids, including sesquiterpenoids, diterpenoids and triterpenoids with 3, 4 and 5 isoprene units, respectively. Phytosterols are sterols of higher photosynthetic plants originated by a biosynthetic pathway of cyclisation, where squalene is the precursor (Kozlowski and Pallardy 1997, Simoneit et al. 1991a), which can be selected by searching $m / z 129$. Besides the precursor, the most common phytosterols that have been found in the solvent-extractable fraction of organic aerosols, derived from vegetation waxes and plant lipid membranes (Oros and Simoneit 2001a, b), consist of ergosterol $\left(\mathrm{C}_{27}\right)$, campesterol $\left(\mathrm{C}_{28}\right)$, sitosterol $\left(\mathrm{C}_{29}\right)$ and stigmasterol $\left(\mathrm{C}_{29}\right)$. Whereas sitosterol and stigmasterol are indicators for vegetation in general, campesterol has been pointed out as a specific molecular tracer for gramineae (Simoneit 2002). Different carbon number distributions have been obtained in distinct experiments, suggesting that the phytosterol patterns may be related to geographical characteristics, particularly, the specific plant communities and the climatic conditions. For example, aerosol samples from both rural and urban western United States compare with $\mathrm{C}_{27}>\mathrm{C}_{29}>\mathrm{C}_{28}$ distribution of the wax from the Sierra Nevada vegetation or Oregon coastal forest (Simoneit 1989). For aerosol samples from Nigeria, an inverted ordering was encountered, where the pattern $\mathrm{C}_{29}>\mathrm{C}_{27}>\mathrm{C}_{28}$ was evident. This distribution correlated with the predominance of wax components from the Nigerian and desert vegetation and also from grass (Simoneit et al. 1988). The Nigerian phytosterol pattern coincides with that of aerosol samples and composites from the Amazon region (Simoneit et al. 1990). In aerosols from a Portuguese semi-rural area and from a Greek Abies forest, the $\mathrm{C}_{28}$ phytosterol was not present at detectable levels and a $\mathrm{C}_{27}>\mathrm{C}_{29}$ distribution was observed (Alves and Pio, in press).

Sesquiterpenoid compounds possess in their structures the cadinane skeleton, an important constituent of resin plants (Simoneit and Mazurek 1982). Some sesquiterpenoids of lower volatility have been detected in aerosols from rural locations, including bicyclic (e.g. caryophyllene, cadalene and calamenene) and tricyclic (e.g. longifolene, copaene and patchoulol) constituents (Alves and Pio, in press, Pio et al. 2001b).

Diterpenoid components derive from the steroid skeletons of abietane and pimarane, which are the major constituents produced by higher plants, especially conifers (Standley and Simoneit 1994). Oxidation, polymerisation, disproportionation and aromatisation reactions of these unstable diterpenoids produce secondary compounds, such as resin acids (Pio et al. 2001a, Simoneit and Mazurek 1982). Retene (1-methyl-7-isopropylphenanthrene), a completely dehydrogenated resin diterpenoid, is a pyrolysis end product from diterpenoids that have the abietane or pimarane skeletons and has been proposed as molecular tracer for coniferous wood combustion (Ré-Poppi and Santiago-Silva 2002, Rogge et al. 1998, Simoneit and Mazurek 1982, Standley and Simoneit 1994).

Resin acids are protectants and wood preservatives that are produced by parenchymatous epithelial cells that surround the resin ducts in trees from temperate coniferous forests. The resin acids are formed when twoand three-carbon molecules couple with isoprene building units to form mono-, sesqui-, and diterpene structures. Resin acids have two functional groups, carboxyl group and double bonds. Nearly all have the same basic skeleton: a 3-ring fused system with the empirical formula $\mathrm{C}_{19} \mathrm{H}_{29} \mathrm{COOH}$. Resin acids, which are biosynthesised mainly by gymnosperms (e.g. pine and spruce) in temperate regions (Oros and Simoneit 1999, Rogge et al. 1998, Simoneit et al. 1993), are generally found in aerosols in significant concentrations. They include unaltered (levopimaric, pimaric, isopimaric and sandaracopimaric acids) and thermal degradation products (neoabietic, palustric, dehydroabietic and 7-oxodehydroabietic acids). Dehydroabietic acid has been used as a biogenic source indicator for conifer resin, either directly 
TABLE VIII

Dominant source-specific molecular markers for smoke from each coal type.

\begin{tabular}{l|c}
\hline \multicolumn{1}{c|}{ Coal type } & Markers \\
\hline Lignite & $\begin{array}{c}\text { Dominant } \mathrm{C}_{31} \text {-hopanes, divanillyl and 1,2-divanillylethane lignans, } \\
\text { diterpenoids and dehydrogenated and 3-oxo triterpenoid derivatives }\end{array}$ \\
\hline Brown coal & $\begin{array}{c}\text { Allobetul-2-ene, 3,4,7-trimethyl-1,2,3,4-tetrahydrochrysene and } \\
1,2-(5 \text { '-isopropylcyclopenteno)-7-methylchrysene }\end{array}$ \\
\hline Sub-bituminous coal & $\begin{array}{c}17 \beta(\mathrm{H}), 21 \beta(\mathrm{H}) \text {-hopane, } \mathrm{C}_{28} \text { triterpenoids and } \\
\text { 2,2-dimethyl-1,2,3,4-tetrahydropicene }\end{array}$ \\
\hline Bituminous coal & Picene and methylpicenes \\
\hline
\end{tabular}

to the aerosol, or from combustion of wood (Graham et al. 2004, Standley and Simoneit 1994). This compound was not identified in aerosols from Nigeria and Amazonia, in accordance with the absence of conifer vegetation in those regions (Simoneit et al. 1988, 1999). In cities where wood is used for heating, ambient dehydroabietic acid concentrations ranged from 48 to $440 \mathrm{ng} \mathrm{m}^{-3}$ (Standley and Simoneit 1994). The compound was also detectable in oceanic samples at concentrations ranging from 0.0001 to $0.4 \mathrm{ng} \mathrm{m}^{-3}$, whereas in terrestrial aerosol particulate matter, it was present at much higher levels (0.23-440 $\left.\mathrm{ng} \mathrm{m}^{-3}\right)$. The presence of this tracer in atmospheric matter over the ocean confirmed the long-range transport of smoke from biomass burning of the continents (Simoneit and Elias 2001).

In smoke samples from biomass combustion (Table IX), triterpenoids are used as organic tracers for the contribution of directly volatilised natural constituents from vegetation (Elias et al. 1997). The most encountered triterpenoids in plants are $\alpha$-amyrin, $\beta$-amyrin and their derivatives. These pentacyclic triterpenes have been considered tracers for angiosperm waxes, especially in their gums and mucilages (Oros and Simoneit 2001a, b). Their biosynthesis proceeds from squalene-2,3-epoxide to the basic ursane and oleanane skeletons and further oxidative steps lead to triterpenic acids and other pentacyclic oxygenated compounds (Simoneit 1989). Simoneit et al. (1991c) found various triterpenoids in aerosols from mountainous regions and from the southeast coast of Australia. Global yields ranged from 0.4 to $6 \mathrm{ng} \mathrm{m}^{-3}$. The same investigators detected amyrinols, at trace levels, in aerosol samples taken from Amazonia (Simoneit et al. 1990). Alves and Pio (in press) detected triterpenic oxygenated compounds such as amyrinol and deriva- tives in aerosols from Portuguese and Greek rural areas. In smoke aerosol from Amazonia, high molecular weight components consisting of a series of wax esters (long chain alcohols esterified with long chain fatty acids) with up to 58 carbon numbers, triglycerides and triterpenyl esters (e.g. $\alpha$ - and $\beta$-amyryl stearate) were detected (Elias et al. 1997, 1998). Some of the structures are represented in Figure 4.

Lignin is a biopolymer that represents a substantial portion of wood, deriving primarily from $p$-coumaryl, coniferyl and sinapyl alcohols. Breakdown products are emitted upon combustion of wood, including aromatic phenols, aldehydes, ketonic acids and alcohols. In the smoke emissions, some volatilised thermal combustion products condense on pre-existing smoke particles. Because the monomers in the lignin are linked via the substituent para to the $-\mathrm{OH}$ group to the polymer, the lignin breakdown products disagree only in that substituent (Rogge et al. 1998). Both hard and softwoods produce guaiacol (2-methoxyphenol) derivatives in the smoke, whereas hardwood originates high levels of syringeol (1,3-dimethoxy-phenol) derivatives in addition (Hawthorne et al. 1988, Simoneit 2002). Vanillin and vanillic acid are detected in pine wood smoke. Minor amounts of syringaldehyde, syringic acid and $p$-anisic acid are also present. Hardwood smoke (e.g. oak) is enriched in syringaldehyde and syringic acid, showing minor amounts of other sinapyl- and vanillyl-type constituents. Grass smoke consists of $p$-anisaldehyde, $p$-anisic acid and, in less extent, $p$-coumaryl, vanillyl- and syringyltype lignin pyrolysis products (Simoneit 2002). Other lignin products such as veratrol (dimethoxy-benzene) and veratric acid (3,4-dimethoxy-benzoic acid) are examples of compounds that have been detected in the par- 
TABLE IX

Molecular tracers for biomass burning aerosols.

\begin{tabular}{|c|c|c|c|c|}
\hline Chemical group & Molecular markers & Molecular structures & MS key ions and $\mathrm{M}^{+}$ & Source \\
\hline \multirow{3}{*}{$\begin{array}{c}\text { Monosaccharide } \\
\text { derivatives }\end{array}$} & Levuglocosan & & $73,204,217,333,378$ (as TMS) & Biomass with cellulose \\
\hline & Galactosan & & $73,204,217,333,378$ (as TMS) & Biomass with cellulose \\
\hline & Mannosan & & $73,204,217,333,378$ (as TMS) & Biomass with cellulose \\
\hline \multirow{5}{*}{ Methoxyphenols } & Vanillin & & $123,137,151$ & Conifers \\
\hline & Vanillic acid & & $73,267,297,312$ (as TMS) & Conifers \\
\hline & Syringaldehyde & & 182 & Angiosperms \\
\hline & Syringic acid & & $73,312,327,342$ (as TMS) & Angiosperms \\
\hline & $\begin{array}{l}\text { p-Hydroxybenzoic } \\
\text { acid }\end{array}$ & & $\begin{array}{c}77,82,105,111,136,142 \\
\text { (as methyl ester) }\end{array}$ & Gramineae \\
\hline \multirow{4}{*}{ Diterpenoids } & Abietic acid & & $73,241,256,359,374$ (as TMS) & Conifers \\
\hline & Pimaric acid & & $73,121,257,359,374$ (as TMS) & Conifers \\
\hline & Iso-pimaric acid & & $73,241,256,359,374$ (as TMS) & Conifers \\
\hline & $\begin{array}{c}\text { Sandaracopimaric } \\
\text { acid }\end{array}$ & & $73,121,241,257,359$ (as TMS) & Conifers \\
\hline
\end{tabular}

ticulate matter (Alves and Pio, in press). Furan derivatives (e.g. 2-acetylfuran, 2-furanmethanol) have been described as minor constituents of smoke and attributed to cellulose combustion/decomposition process (Edye and Richards 1991, Simoneit 2002). Lignans are present as noteworthy components in the smoke from softwood 
TABLE IX (Continuation)

\begin{tabular}{|c|c|c|c|c|}
\hline Chemical group & Molecular markers & Molecular structures & MS key ions and $\mathrm{M}^{+}$ & Source \\
\hline \multirow{3}{*}{ Diterpenoids } & Dehydroabietic acid & & $73,239,357,372$, (as TMS) & Conifers \\
\hline & Pimanthrene & & 191,206 & Conifers \\
\hline & Retene & & 219,239 & Conifers \\
\hline \multirow{3}{*}{ Triterpenoids } & $\alpha-$ Amyrin & & $73,189,203,218,393,483,488$ & Angiosperms \\
\hline & $\beta$-Amyrin & & $73,189,203,218,393,483,498$ & Angiosperms \\
\hline & Lupeol & & 189, 203, 218, 231, 279, 369, & Angiosperms \\
\hline \multirow{3}{*}{ Phytosterols } & $\beta$-Sitosterol & & $137,151,167,181,402$ & $\begin{array}{l}\text { All biomass } \\
\text { sources }\end{array}$ \\
\hline & Stigmasterol & & $83,129,255,394,469,484$ & $\begin{array}{l}\text { All biomass } \\
\text { sources }\end{array}$ \\
\hline & Campesterol & & $73,129,343,367,382,457,472$ & Gramineae \\
\hline
\end{tabular}




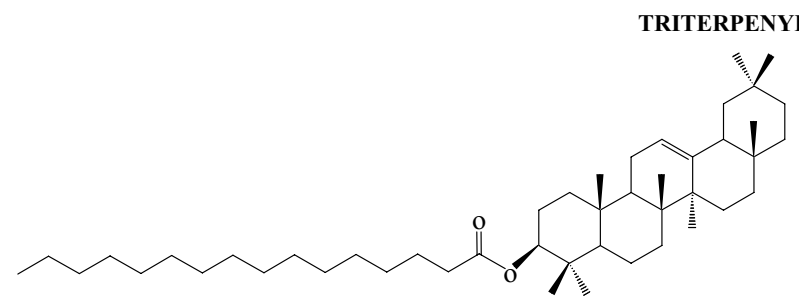

$\beta$-amyryl palmitate

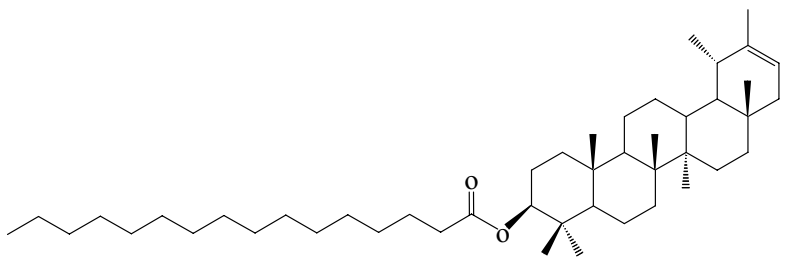

Taraxasteryl palmitate

TRIGLYCERIDES

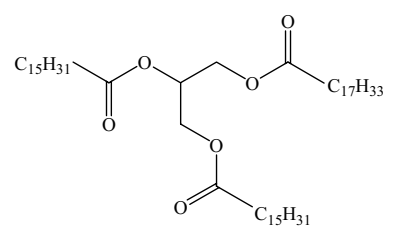

Dipalmitoylolein

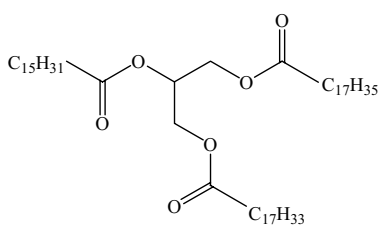

1-Palmitoyl-2-oleoyl-3-stearin

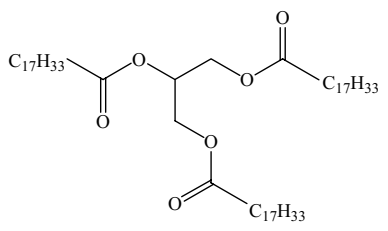

Triolein

Fig. 4-Structures of some compounds representative of the homologous series of triterpenols esterified to long chain fatty acids and of triglycerides in smoke extract from Amazonia.

(e.g. pine), are less significant in the hardwood smoke (e.g. oak) and are not measurable in grass smoke (Simoneit et al. 1993). The leading lignans of softwood smoke are matairesinol and shonanin (tetrahydro-3,4divanillyfuran). Minor quantities of methylated derivative are detectable. The hardwood smoke encompasses a variety of highly oxygenated isomers of dihydrovanillylsyringyl-2(3H)-furanone, dihydro-3(2', 3', 4'-trimethoxybenzyl) - 4 - veratryl - 2(3H) - furanone and tetrahydro-3-vanillyl-4-veratrylfuran, which are released unaltered from the combustion sources and may be considered tracers of biomass burning. In addition, softwood smoke includes derivatives from coniferyl-type precursors, such as divanillyl, divanillylmethane, bis(3,4dimethoxyphenyl)methane and diveratryl. Hardwood smoke comprises components originated from sinapyltype precursors, including bisguaiacylsyringyl, disyringyl and bis(3,4,5-trimethoxyphenyl)ethane. Dianisyl, a derivative from a $p$-coumaryl-type precursor, is the only tracer in the grass smoke (Simoneit 2002).

The pyrolysis derivatives from the thermal break- down of cellulose and hemicellulose during burning are the dominant smoke tracers in continental air sheds. The major tracer compound is levoglucosan, with lesser amounts of galactosan and mannosan. These are the tracers utilised for the assessment of particulate matter from biomass burning in the atmosphere because they cannot be generated by non-combustive processes. They are characterised by the base peak at $m / z 204$ and by $m / z 217$ and 333 in mass fragmentograms. The mass spectrum of levoglucosan tritrimethylsilyl ether exhibits only a small molecular ion $(\mathrm{m} / \mathrm{z} 378)$ with fragments due to loss of $\mathrm{CH}_{3}(m / z 363), \mathrm{CH}_{5} \mathrm{Si}(m / z 333), \mathrm{C}_{6} \mathrm{H}_{17} \mathrm{OSi}_{2}$ ( $m / z$ 217) and $\mathrm{C}_{7} \mathrm{H}_{18} \mathrm{OSi}_{2}(m / z$ 204, base peak). The mass spectra of the other monosaccharide dehydration derivatives (galactosan and mannosan) are similar (Abas et al. 2004a, Pashynska et al. 2002). Levoglucosan is emitted in relatively high concentrations, $40 \mathrm{mg} \mathrm{kg} \mathrm{m}^{-1}$ to $1200 \mathrm{mg} \mathrm{kg}^{-1}$ of wood burned, and shows no decay over an eight-hour exposure to ambient atmospheric conditions (Larsen et al. 2006). Potential acid-catalysed hydrolysis of levoglucosan in atmospheric droplets was 
TABLE X

Elemental carbon, organic carbon and levoglucosan in fine particulate matter from different categories of biomass burning measured recently in different investigatios (adapted from Puxbaum et al. 2007).

\begin{tabular}{|c|c|c|c|c|c|c|}
\hline Sampling site & Fuel category & $\begin{array}{l}\mathrm{EC} \mathrm{mg} / \mathrm{g} \\
\text { of } \mathrm{PM}_{2.5} \\
\end{array}$ & $\begin{array}{l}\mathrm{OC} \mathrm{mg} / \mathrm{g} \\
\text { of } \mathrm{PM}_{2.5} \\
\end{array}$ & $\begin{array}{c}\text { Levoglucosan } \\
(\mathrm{mg} / \mathrm{g} \mathrm{OC})\end{array}$ & $\begin{array}{c}\text { Factor } \\
\text { OC/Levogl. }\end{array}$ & Reference \\
\hline \multirow{2}{*}{$\begin{array}{l}\text { Fireplace } \\
\text { NE-US }\end{array}$} & Hardwood & & 866 & 129 & 6.7 & \multirow{2}{*}{ Fine et al. 2001} \\
\hline & Softwood & & 911 & 76.4 & 11.9 & \\
\hline \multirow{2}{*}{$\begin{array}{l}\text { Fireplace } \\
\text { South-US }\end{array}$} & Hardwood & & 787 & 136 & 5.8 & \multirow{2}{*}{ Fine et al. $2002 \mathrm{a}, \mathrm{b}$} \\
\hline & Softwood & & 1000 & 42.6 & 23.5 & \\
\hline \multirow{2}{*}{$\begin{array}{c}\text { Fireplace Mid-W } \\
\text { and W-US } \\
\end{array}$} & Hardwood & 20 & 767 & 183 & 4.2 & \multirow{2}{*}{ Fine et al. $2004 c$} \\
\hline & Softwood & & 890 & 123 & 7.2 & \\
\hline \multirow{2}{*}{ Wood stove US } & Hardwood & & 553 & 164 & 3.4 & \multirow{2}{*}{ Fine et al. 2004a } \\
\hline & Softwood & & 620 & 353 & 1.8 & \\
\hline $\begin{array}{c}\text { Asian biomass } \\
\text { fuel }\end{array}$ & $\begin{array}{l}\text { Leaves, straw, } \\
\text { dung, etc. }\end{array}$ & 32.4 & 525 & 79 & 6.6 & Sheesley et al. 2003 \\
\hline $\begin{array}{l}\text { Rhondonia } \\
\text { Pasture Site }\end{array}$ & & 1.4 & 29.2 & 2.46 & 11.9 & \multirow{2}{*}{ Graham et al. 2003} \\
\hline $\begin{array}{l}\text { Rhondonia } \\
\text { Forest Site }\end{array}$ & & 0.7 & 14.5 & 1.18 & 12.3 & \\
\hline $\begin{array}{c}\text { Southern } \\
\text { United States } \\
\end{array}$ & $\begin{array}{c}\text { Fresno } \\
\text { Rural-urban }\end{array}$ & & 32.7 & 7.6 & 4.3 & $\begin{array}{l}\text { Schauer and Cass } \\
2000\end{array}$ \\
\hline $\begin{array}{c}\text { Southeast } \\
\text { Asia }\end{array}$ & $\begin{array}{c}\text { Kuala Lumpur } \\
\text { Urban-haze }\end{array}$ & & 115 & 40.24 & 2.9 & Abas et al. 2004a \\
\hline $\begin{array}{l}\text { Recommended } \\
\text { average US }\end{array}$ & & & & & 7.35 & Fine et al. 2002a, b \\
\hline $\begin{array}{l}\text { Recommended } \\
\text { for small } \\
\text { stoves Austria }\end{array}$ & & & & & $7.1 *$ & Schmidl 2005 \\
\hline
\end{tabular}

investigated as one potential loss mechanism. Results using simulated rainwater indicate no degradation over a 10-day period (Fraser and Lakshmanan 2000). Thus, it is a good candidate for tracing biomass burning emissions. Levoglucosan has been detected in atmospheric aerosols from U.S. urban areas, e.g. Seattle, 13-750 $\mathrm{ng} \mathrm{m}^{-3}$ (Simpson et al. 2004), Fresno and Bakersfield, 23$7590 \mathrm{ng} \mathrm{m}^{-3}$ (Schauer and Cass 2000), and about $120 \mathrm{ng} \mathrm{m}^{-3}$ in Los Angeles (Fine et al. 2004b). In a Portuguese semi-rural coastal area, during the 2003 summer intense forest fire period, levoglucosan presented levels between a minimum of $17 \mathrm{ng} \mathrm{m}^{-3}$ and an upper limit of $105 \mathrm{ng} \mathrm{m}^{-3}$ (Pio et al. 2007), which was achieved during a vast wildfire period. Much higher average levels of 1200 and $2500 \mathrm{ng} \mathrm{m}^{-3}$ have been reported for forest and pasture sites, respectively, in 1999, during the burning season in Rhondonia, southwest Amazonia (Graham et al. 2002). However, these values are far lower than concentrations that have been reported during severe episodes of biomass smoke in Southeast Asia, 1400-40240 $\mathrm{ng} \mathrm{m}^{-3}$ (Abas et al. 2004a). Table X presents the contribution of levoglucosan to $\mathrm{OC}$ in fine particles from different fuel types and distict burning conditions. Based on the average value between the OC/levoglucosan ratio of 12.3 measured for the fine dry season aerosol in Rhondonia (Graham et al. 2002) and the ratio of 10.5 obtained for a pine forest fire in southeast USA (Lee et al. 2005), it was found a smaller than expected contribution (11-36\%) of wood combustion to the amount of OC throughout the summer of 2003, which was characterised by an intense heat wave and forest fires in Portugal (Pio et al. 2007). Thus, unrealistically, its seems that the major fraction of OC measured in both fine and coarse aerosols during the Portuguese study was chiefly related to other primary anthropogenic and biogenic sources, as well secondary formation processes. In spite of a noteworthy 
raise in OC levels during the two weeks with strongest impact from the forest fire smoke plumes, the levoglucosan concentrations and the estimated contribution of wood burning to OC did not increase as expected. However, if the average levels of OC and levoglucosan measured during the 3 weeks less affected by wildfires were taken as baseline values and if these values were subtracted from the corresponding concentrations during the intense forest fire periods, then an OC/levoglucosan ratio of 80 was obtained. The investigation of Pio et al. (2007) made evident that the $\mathrm{OC} /$ levoglucosan relationships proposed in the literature for deriving the amount of $O C$ from wood or biomass combustion in ambient aerosols should be taken with precaution. Since the ratios are quite variable for different burning conditions and wood types, it has yet to be estimated more specific factors with application to wildfires under extreme weather conditions (dryness and high temperatures), such as those in the Mediterranean countries. This conclusion was consistent with the results presented by Jordan et al. (2006), who obtained a smaller than expected levoglucosan mass fraction in aerosols generated by bushfires after using factors determined for wood burning. The different fuel and combustion conditions encountered during bushfires gave rise to lower mass fractions.

Besides anhydrosugars, recent studies indicate that sugar polyols and sugars are relatively abundant watersoluble organic constituents of atmospheric aerosols (Table XI). Saccharide alcohols (reduced sugars) are known components of bacteria, fungi, lichens, invertebrates and lower plants, acting as osmoregulators, stress inhibitors or carbohydrate suppliers (Graham et al. 2003, Medeiros et al. 2006). There are several sources of monosaccharides including microorganisms, vascular plants and animals (Medeiros et al. 2006). Simoneit et al. (2004b) suggested soil and associated microbiota as the main source of sugars to the atmosphere. According to these researchers, all these compounds derive mainly from soil resuspension into the atmosphere, though emissions of considerable amounts may occur by thermal stripping during biomass burning events. The dominant primary saccharides in aerosols include $\alpha$ - and $\beta$-glucose, sucrose and mycose (trehalose) with various minor constituents.

\section{OXIDATION PRODUCTS OF VOC}

The fraction of particulate organics resulting from the conversion of volatile compounds is of particular interest for the understanding of the chemistry of rural atmospheres, because of the large VOC emissions from vegetation in these areas. These compounds have an exceptional ability to produce condensable products as result of rapid oxidation into less volatile oxygenated organics. Among biogenic emissions from vegetation, $50 \mathrm{Tg}$ of $\alpha$-pinene are emitted per year, which is almost $45 \%$ of the estimated global annual emission of monoterpenes (Bhat and Fraser 2007). Terpene and isoprene oxidation products have been observed in aerosols in smog chamber studies and in the ambient atmosphere (Alves and Pio 2005, Alves et al. 2000, 2001, 2002, 2006, Bhat and Fraser 2007, Böge et al. 2006, Cahill et al. 2006, Claeys et al. 2004a, b, 2007, Clements and Seinfeld 2007, Edney et al. 2003, 2005, Engling et al. 2006, Herckes et al. 2006, Jaoui and Kamens 2003, Jaoui et al. 2005, Kavouras et al. 1998b, 1999b, c, Kavouras and Stephanou 2002a, b, Lewandowski et al. 2007, Oliveira et al. 2007b, Pio et al. 2001a, b, Sheesley et al. 2004, Spanke et al. 2001, Yu et al. 1999).

Pinic acid, pinonic, pinonaldehyde and nopinone are common pinene oxidation products detected both in smog chamber and field experiments (Table XII). The ozonolysis of $\alpha$-pinene is a known source of pinic acid (e.g. Christoffersen et al. 1998). Another pathway for the formation of this compound is the reaction of $\beta$ pinene with $\mathrm{O}_{3} / \mathrm{NO}_{x}$ (Jaoui and Kamens 2003). In laboratory experiments with $\alpha$-pinene and $\mathrm{OH}$ radicals or ozone, the formation of pinonaldehyde and pinonic acid was observed (Hakola et al. 1994, Kamens and Jaoui 2001, Larsen et al. 2001). Pinonaldehyde may also take place in the particulate phase by oxidation of $\alpha$ pinene through reaction with other oxidising species such as $\mathrm{NO}_{3}$ and $\mathrm{N}_{2} \mathrm{O}_{5}$ (Wängberg et al. 1997). The major product from $\beta$-pinene oxidation identified in the particulate matter is nopinone. This compound has been detected in laboratory studies as a product of the precursor through reaction with $\mathrm{O}_{3}$ or $\mathrm{OH}$ (e.g. Hakola et al. 1994, Jaoui and Kamens 2003, Larsen et al. 2001). The formation of nopinone may also take place after oxidation of $\beta$-pinene by $\mathrm{NO}_{x}$ (Grosjean et al. 1992, Paulson et al. 1990), $\mathrm{O}_{3} / \mathrm{NO}_{x}$ (Palen et al. 1992) or $\mathrm{NO}_{x} / \mathrm{SO}_{2}$ (Kotzias et al. 1990). 


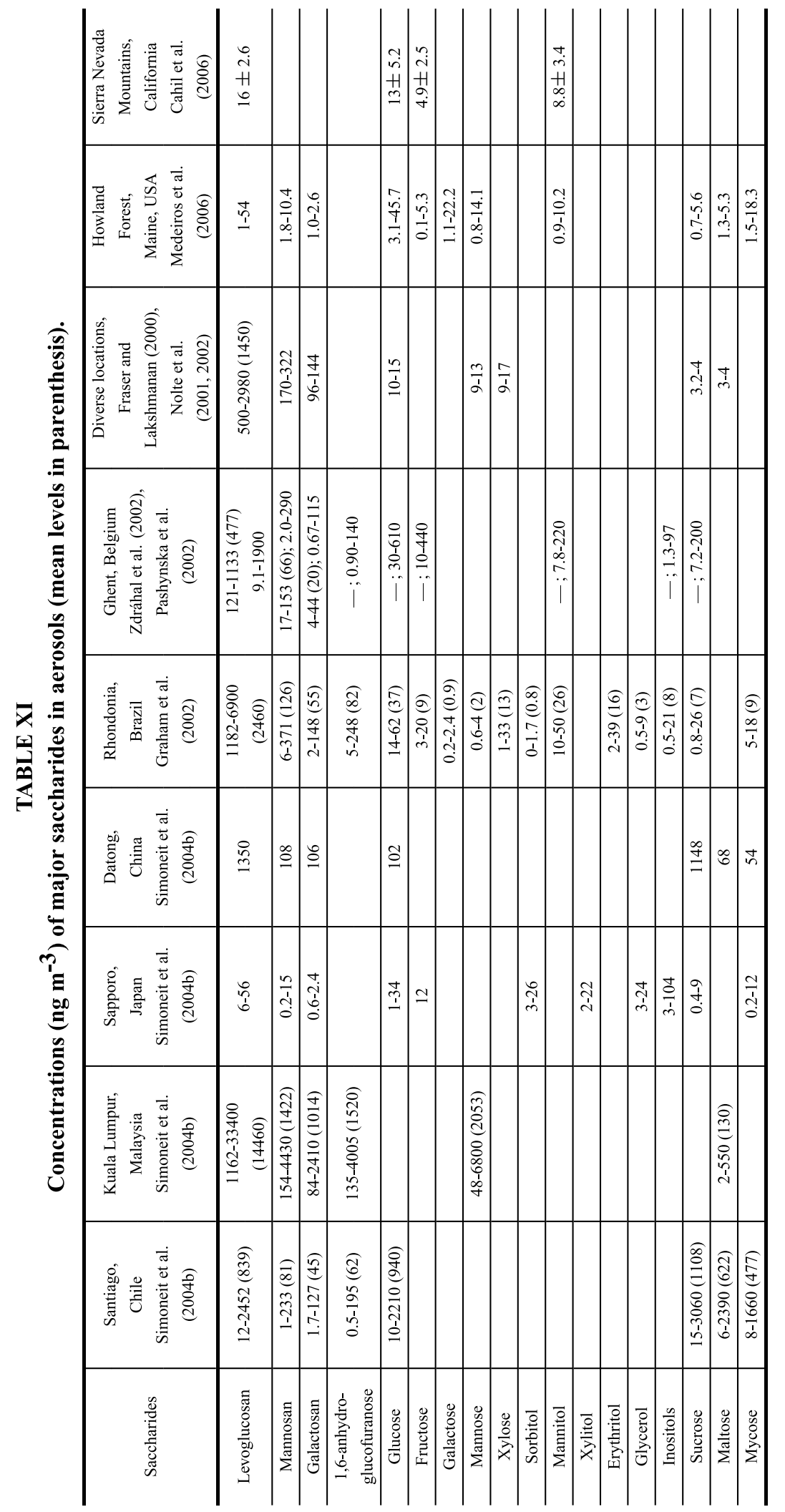


TABLE XII

Concentrations $\left(\mathrm{ng} \mathrm{m}^{-3}\right)$ of some terpene photo-oxidation products detected in aerosols from field experiments.

\begin{tabular}{|c|c|c|c|c|c|}
\hline Sampling site & Reference & $\begin{array}{c}\text { Pinonic acid } \\
y_{\mathrm{coOH}}^{\mathrm{o}}\end{array}$ & $\underset{\substack{\mathrm{COOH} \\
\text { Pinic acid }}}{ }$ & Nopinone & Pinonaldehyde \\
\hline Two Japanese mountains & Satsumabayashi et al. (1990) & & & & $30-100$ \\
\hline Near Ispra, Italy & Calogirou et al. (1997) & & & & 90 \\
\hline $\begin{array}{l}\text { Kejimkujik National Park (Nova Scotia) } \\
\text { and San Bernardino National Forest } \\
\text { (California) }\end{array}$ & Yu et al. (1999) & $0.1-0.8$ & $0.5-0.6$ & & $0.2-1.0$ \\
\hline Eucalyptus forest, Portugal & Kavouras et al. (1998b) & $\begin{array}{c}\text { 7.1-60.1 (isomer } \text { cis); } \\
1.5-42.9 \text { (isomer trans) }\end{array}$ & & $0.0-13.2$ & $0.2-32.1$ \\
\hline Boreal forest & Spanke et al. (2001) & $0.8-4.0$ (pinonic+pinic acids) & & & \\
\hline Greek conifer forest & $\begin{array}{l}\text { Kavouras et al. (1999b) } \\
\text { Pio et al. (2001a) }\end{array}$ & $<25.7$ & $<4.4$ & $<0.6$ & $<1.2$ \\
\hline Giesta, rural, Portugal & Pio et al. (2001b) & & 6.8 & 1.4 & \\
\hline Aveiro, coastal city, Portugal & Alves et al. (2002) & 25.3 & 15.8 & 2.4 & 13.7 \\
\hline Lisbon, Portugal & Alves et al. (2002) & 1.0 & $<0.5$ & $<0.1$ & $<0.5$ \\
\hline Lower Fraser Valley, Vancouver & Cheng et al. (2004) & 5.9 & & & \\
\hline Sierra Nevada Mountain, CA & Cahill et al. (2006) & $2.6-37$ & $1.7-10$ & $1.5-5.1$ & $16-320$ \\
\hline Yosemite National Park, CA & Engling et al. (2006) & 21 & 12 & 0.9 & 21 \\
\hline Hyytiälä, boreal forest, Finland & Alves et al. (2006) & 2.6 & 5.0 & 0.2 & 5.5 \\
\hline Melpitz, German meadow & Alves et al. (2006) & 7.8 & 7.2 & 0.1 & 14 \\
\hline Coniferous forest, Germany & Plewka et al. (2006) & 2.5 (night); 3.5 (day) & 3.2 (night); 9.5 (day) & & 13.7 (night); 2.7 (day) \\
\hline Duke Forest (pine), North Carolina & Bhat and Fraser (2007) & $0.11-20.8$ & $1.5-25.1$ & & \\
\hline Oporto, Portugal & Oliveira et al. (2007a) & $\begin{array}{l}\text { 2.9-3.6 (winter); } \\
\text { 2.9-5.2 (summer) }\end{array}$ & & & \\
\hline Copenhagen, Denmark & Oliveira et al. (2007a) & $\begin{array}{l}2.0-3.8 \text { (winter); } \\
\text { 2.8-3.6 (summer) }\end{array}$ & & & \\
\hline
\end{tabular}

Although monoterpenes are an important source of biogenic organic aerosols (Kavouras et al. 1999c, Hoppel et al. 2001), we still have missing sources that contributes to secondary organic aerosols of biological origin. Matsunaga et al. (2003) measured, in both gas and particle phases, glycolaldehyde and hydroxyacetone which are known as the oxidation products of isoprene (Atkinson 1990), together with biogenic semi-volatile aldehydes ( $n$-nonanal and $n$-decanal; Kesselmeier and Staudt 1999). These investigators discovered a strong diurnal variation of these carbonyls with their particulate concentrations being comparative to the oxidation product of monoterpenes (pinonic acid). They are most likely produced in and/or emitted to the atmosphere as gases, and later converted to the particles. This study demonstrated that the semi-volatile carbonyls largely contribute to the formation and growth of aerosols in the forest and potentially play a significant role in the global budget of organic aerosols. Matsunaga et al. (2004) measured particulate concentrations of 4-oxopentanal (4OPA) up to $207 \mathrm{ng} \mathrm{m}^{-3}$ in a Japonese forest, which was found to be comparable to those of pinonic acid, indicating that 4-OPA is also an important constituent of organic aerosols in the forestal atmosphere. This carbonyl is produced by the oxidation of 6-methyl-5-hepten-2-one, which is heterogeneous oxidation product of squalene and similar terpenoids present on the surface of plant leaves and other parts.

The organic analysis of $\mathrm{PM}_{2.5}$ rural aerosol collected during summer at K-puszta, Hungary, from a mixed deciduous/coniferous forest showed the presence of polar oxygenated compounds that are also formed in laboratory irradiated $\alpha$-pinene/ $\mathrm{NO}_{x} /$ air mixtures (Claeys et al. 2007). The unknown photo-oxidation products were structurally identified as 3-hydroxyglutaric acid, 3-hydroxy-4,4-dimethylglutaric acid and 2-hydroxy-4isopropyladipic acid. The detection of 3-hydroxyglutaric acid and 2-hydroxy-4-isopropyladipic acid at appreciable levels during daytime (avg. 16.8 and $14.9 \mathrm{ng} \mathrm{m}^{-3}$, respectively), provided an explanation for the relatively low atmospheric concentrations of pinic acid in forest environments, since these two acids correspond to a further reaction product of pinic acid involving addition of a molecule of water and opening of the dimethylcyclobutane ring. The same three oxygenated products were detected in samples collected from Research Triangle Park, NC, USA, during the summer of 2003 (Lewandowski et al. 2007). Methyltetrols, along with 2-methylglyceric acid, were also observed. It has been suggested that these compounds may be the products of isoprene oxidation (Böge et al. 2006, Claeys et al. 2004b, Edney et al. 2005). The concentrations of 2-methylthreitol 
and 2-methylerythritol ranged from 18 to $365 \mathrm{ng} \mathrm{m}^{-3}$ $(0.9 \%$ of the total organic matter), suggesting that isoprene SOA may be a significant component of ambient $\mathrm{PM}_{2.5}$ in the southeastern US during the summer (Lewandowski et al. 2007). Other studies have reported methyltetrol levels of up to $29.4 \mathrm{ng} \mathrm{m}^{-3}$ in the Southeast during June of 2004 (Clements and Seinfeld 2007) and $131 \mathrm{ng} \mathrm{m}^{-3}$ in the northeastern US during the summer of 2005 (Xia and Hopke 2006). The discrepancies in the reported concentrations are due, in part, to the absence of authentic standards for the methyltetrols and, consequently, to variations in the quantification methods employed. However, a more important aspect contributing to the high methyltetrol levels detected in aerosols from the Research Triangle Park may be the deliberate choice of stagnant, highly polluted days for sample collection (Lewandowski et al. 2007). During the July 2001 LBA-CLAIRE wet season campaign in the Amazonian rainforest in Balbina, Brazil, Claeys et al. (2004a) detected 2-methylthreitol and 2-methylerythritol, in ambient $\mathrm{PM}_{2.5}$ samples, at total concentrations of $49 \mathrm{ng} \mathrm{m}^{-3}$ during the day and $65 \mathrm{ng} \mathrm{m}^{-3}$ at night. These two tetrols were also observed in ambient $\mathrm{PM}_{2.5}$ in a mixed deciduous/coniferous forest at K-puszta, Hungary, ranging from 1 to $34 \mathrm{ng} \mathrm{m}^{-3}$ and from 1 to $85 \mathrm{ng} \mathrm{m}^{-3}$, respectively, during the summer of 2003 (Ion et al. 2005). In the Hungarian study, the polar oxygenated compound 2-methylglyceric acid was observed at ambient levels ranging between $2 \mathrm{ng} \mathrm{m}^{-3}$ and $18 \mathrm{ng} \mathrm{m}^{-3}$. Two diastereoisomeric 2-methyltetrols were detected in aerosol samples collected in the Sierra Nevada Mountains of California (Cahill et al. 2006), with 2-methylthreitol $\left(32 \pm 9.6 \mathrm{ng} \mathrm{m}^{-3}\right)$ being about 2.5 fold more abundant than 2-methylthreitol $\left(13 \pm 3.8 \mathrm{ng} \mathrm{m}^{-3}\right)$, which is a similar ratio as determined for the Amazon (Claeys et al. 2004a), and boreal Finnish forests (Kourtchev et al. 2005). The concentrations $\left(05-1.7 \mathrm{ng} \mathrm{m}^{-3}\right)$ measured at Melpitz, Germany (Böge et al. 2006) are by far lower than in the other places, especially in Amazonia. However, the isoprene mixing ratio in the Amazonian rainforest was between 4 and $10 \mathrm{ppb}$ (Claeys et al. 2004a, b), whereas those in Melpitz were usually between 10 and 200 ppt. According to Cahill et al. (2006) this substantiates the ubiquitous nature of the 2-methyltetrols in SOA from very much different ge- ographic regions. Althought the 2-methyltetrols have been considered photochemical products, their concentrations in ambient samples do not always show a clear diurnal cycle, like some of the monoterpene oxidation products (e.g. pinonic acid and pinonaldehyde). An unclear pattern was observed by Cahill et al. (2006), which contrasts with the concentration maxima occurring during the day measured by Ion et al. (2005). These disagreements were attributable to differential meteorological conditions at the sites. Due to the fact that 2methyltetrols may be linearly correlated with glucose and fructose, it has been suggested that the polyols may derive from a similar biological source as the sugars, in addition to the well accepted photochemical pathway (Cahill et al. 2006).

One of the predominant ketones found in the atmospheric aerosol samples is phytone (6,10,14-trimethylpentadecan-2-one). It is produced by thermal alteration and oxidation of phytol emitted from plants, or has a marine origin, and has been proposed as a marker for secondary biogenic aerosol (Abas et al. 1995, Brown et al. 2002, Gogou et al. 1996, Simoneit et al. 1988). This isoprenoid compound has been previously detected in an Abies forest of central Greece (Pio et al. 2001a), rural aerosols from Crete (Gogou et al. 1996), forest and rural locations of Portugal (Alves et al. 2001, 2007; Pio et al. 2001b), a German urban/industrial influenced grassland location (Alves et al. 2006), a coniferous forest in Germany (Plewka et al. 2006), a Finnish boreal forest (Alves et al. 2006, Shimmo et al. 2004a), western United States (Simoneit and Mazurek 1982), Canada (Brown et al. 2002, Cheng et al. 2006), Amazonia (Abas et al. 1995), Nigeria (Simoneit et al. 1988) and Yosemite National Park (Engling et al. 2006) at levels of dozens of $n g \mathrm{~m}^{-3}$.

In addition to previously reported biogenic oxidation products (pinic acid, pinonic acid, norpinic acid, nopinone, and pinonaldehyde), seven multifunctional organic compounds were found by Jaoui et al. (2005) in both field and laboratory samples. These compounds, which were proposed as possible atmospheric tracers for secondary organic aerosol from monoterpenes, were consistent with the following identifications: 3-isopropyl pentanedioic acid, 3-acetyl pentanedioic acid, 3-carboxy heptanedioic acid, 3-acetyl hexanedioic acid, 2-isopro- 
pyl-1 , 2-dihydroxybutanol, 4-isopropyl-2 , 4-dihydroxyhexanol and 3-(2-hydroxy-ethyl)-2,2-dimethyl-cyclobutane carboxylic acid. The occurrence of these compounds suggests that SOA originating from biogenic hydrocarbons are contributing to the regional aerosol burden in the southeastern United States. Several of these compounds also appear to contribute to the global aerosol burden in that they have also been identified in Europe and Brazil (Jaoui et al. 2005).

Kubátová et al. (2000) employed GC/MS after various types of derivatisations for the quantification of dichloromethane extractable compounds in aerosols samples collected in the Amazon basin. Four unkowns were identified: two derivatives of glutaric acid (3-isopropyl pentanedioic acid and 3-acetyl pentanedioic acid), 3acetyl hexanedioic acid and 3-carboxy heptanedioic acid. The biogenic precursors of the novel identified compounds could not be pinpointed, but most likely include monoterpenes and fatty acids. In addition, two tricarboxylic acids (propane-1,2,3-tricarboxylic acid and 3carboxy heptanedioic acid) could be characterised. The oxidative degradation products represented $0.5 \%$ of OC.

Aliphatic diacids and aromatic di-, tri-, and tetraacids have also been reported as indicators of SOA in urban atmospheres, as they can be quantified readily using standard GC/MS techniques (Fine et al. 2004d, Schauer et al. 2002a, Zheng et al. 2002). Nevertheless, in aerosol samples enclosing a mixture of both SOA and primary source emissions, the origins of these compounds have not yet been definitively identified (Sheesley et al. 2004). Aromatic acids, particularly phthalic acid, have been thought to be secondary products of the oxidation of PAH, including naphthalene (Fraser et al. 2003, Jang and McDow 1997), while origins proposed for aliphatic dicarboxylic acids comprise the formation by photochemical oxidation of anthropogenic hydrocarbons and biogenic compounds, direct emission from combustion engines, or biomass combustion (Kubátová et al. 2000 and references therein). Although dicarboxylic acids can be of primary or secondary origin, several studies have revealed contributions to SOA by dicarboxylic acids formed in situ during atmospheric aerosol processing (Glassius et al. 2000, Kavouras et al. 1998b, 1999c, Kawamura et al. 1996). The dicarboxylic acids measured by Engling et al. (2006) during the summer of 2002 in Yosemite National Park (CA, USA) showed a relatively large variability in concentrations throughout the study based on the weekly composite samples (1.3-11 ng m ${ }^{-3}$ for the sum of $\mathrm{C}_{4}$ through $\mathrm{C}_{14}$ dicarboxylic acids). It has been verified that they accumulate in aerosols and account for $1-15 \%$ of the total aerosol carbon and display their highest concentrations during periods of increased solar radiation. In addition to $\omega$ dicarboxylic acids, keto mono- and dicarboxylic acids and $\alpha$-dicarbonyls have also been reported to be atmospheric oxidation products (Kubátová et al. 2000 and references therein).

Jang et al. (2002) showed that some of the highly volatile carbonylic oxidation products can significantly contribute to the increase of SOA mass if mixed with acidic inorganic seed particles. A possible explanation for this is that condensation and polimerisation reactions of carbonyls in the acidic particles contribute to SOA mass increase. Reaction chamber experiments have showed that about $50 \%$ of SOA from aromatic oxidation is composed of polymers with a molecular mass up to 1000 daltons. The formation and ageing processes of these polymeric subtances take more than 20 hours (Kalberer et al. 2004). Because aromatics are the main anthropogenic SOA precursors, these polymers are supposed to be found at appreciable concentrations in urban environments. On the other hand, aldehydes are abundant products of biogenic terpenic compounds and, probably, acetal polymers are formed in large quantities in rural atmospheres. It can be expected that all these polymerisation reactions influence aerosol properties (e.g. optical parameters, hygroscopic growth and cloud condensation nuclei potential) affecting the role in the global climate system (Kalberer et al. 2004, Tolocka et al. 2004). The parametrisation of these reactions is an important and novel issue, which should be addressed in modern aerosol models.

The measurement of SOA comprises inumerous difficulties. They not only are polar but their levels seem to be only a few nanograms per cubic meter. Another difficulty is the partitioning of these compounds between the gas and particulate phases. As most of them are semi-volatile their aerosol fingerprint alters constantly. In addition, some of the most volatile ones (e.g. pinonaldehyde and nopinone) have been shown to have atmo- 
spheric lifetimes of the order of a few hours and their reactivity has not been investigated in any detail. Further research of the stability of these compounds will be needed to better assess their capability as tracers for SOA. Although quantitative collection of both semivolatile and particulate-phase constituents is wanted for tracing SOA, it should be noted that the existing sampling networks are not prepared for the challenge. Thus, it will be necessary to exploit advanced sampling and analytical techniques in order to take advantage of both non-volatile and semi-volatile tracers in source apportionment studies.

\section{MATERIAL BALANCE}

Material balances describing the chemical composition of aerosols collected at a forest site and in cities that face some air pollution problems are shown in Figure 5. The unexpected high levels of particulate matter observed in the Greek wood were attributable to dust contamination from the passage of trucks in nearby unpaved forest roads (Pio et al. 2001a). Background annual average concentrations for continental Europe are $7.0 \pm 4.1 \mu \mathrm{g} \mathrm{m}^{-3}$ and $4.8 \pm 2.4 \mu \mathrm{g} \mathrm{m}^{-3}$ for $\mathrm{PM}_{10}$ and $\mathrm{PM}_{2.5}$, respectively (Dingenen et al. 2004). Querol et al. (2004) reported $\mathrm{PM}_{10}$ levels varying from 28 to $42 \mu \mathrm{g} \mathrm{m}^{-3}$ at urban background and from 37 to $53 \mu \mathrm{g} \mathrm{m}^{-3}$ at kerbside sites in seven selected cities throughout Europe. Annual average levels of 24, 52, 157 and $54 \mu \mathrm{g} \mathrm{m}^{-3}$ were measured in New York, São Paulo, Tegucigalpa and Hong Kong, respectively (Baldasano et al. 2003). In Santiago, the average concentrations of OC $\left(52 \mu \mathrm{g} \mathrm{m}^{-3}\right)$ and EC $\left(31 \mu \mathrm{g} \mathrm{m}^{-3}\right)$ represent $21 \%$ and $13 \%$ of the $\mathrm{PM}_{10}$ particulate matter. These levels are notably higher (factor of 4-10 times) than those described for Los Angeles, New York or the average for 46 USA urban areas (Didyk et al. 2000 and references therein). In the case of the forest samples, the total extractable material contained approximately 2 times more mass than the corresponding OC fraction. Two possible explanations were considered for this difference. Either the solvent extract contained other compounds besides organic matter, and/or the organic matter had an important contribution of other atomic species, such as oxygen, nitrogen and sulphur. The expression "Non C organics?" represents solvent extractable matter, such as oxygen, nitrogen, etc., that is not determined on the black/organic carbon analysis by the thermal/optical method (Pio et al. 2001a). It should be referred that a significant portion of the more polar oxygenated organic compounds are not extractable by common solvents, such as dichoromethane. The organic matter that is extractable and that elutes from the chromatographic columns represents a small fraction (usually less than $10 \%$ ) of the total organic extract. The mass of chromatographically elutable organics can be subdivided into resolved (identifiable peaks) and unresolved complex mixture, consisting above all of cyclic and branched chain hydrocarbons from the incomplete combustion of fossil fuels (Tang et al. 2006). The extractable organic fractions able to separate chromatographically into identifiable compounds are limited to molecules with carbon atoms, in general, less than 40. Thus, macromolecular and other complex components, resulting from oligomerisation and polimerisation processes, which are expected to exist in the aged aerosol particles as result of either direct emission or from secondary atmospheric particulate transformation processes, constitute an analytically non-accessible fraction. The bulk of organic carbon representing more hydrophilic compounds (e.g. dicarboxylic acids, sugar polyols, anhydrosugars, cellulose and humic like substances) are not quantifiable by classic solvent extraction followed by GC/MS. The chromatographically identifiable organic material consists mainly of fatty acids and aliphatic constituents, with minor amounts of alcohols, aldehydes, ketones and aromatic compounds. This characterisation of organic aerosol samples shows that in ru$\mathrm{ral}$ and forested areas oxygenated species and products from terpenes emitted by vegetation constitute the major particulate fraction. Petroleum residues and pyrogenic constituents predominate in urban samples, standing out the aliphatic hydrocarbons and cyclic components derived from vehicular emissions.

\section{GEOCHEMICAL PARAMETERS, DIAGNOSTIC RATIOS AND LIPID SOURCE ASSIGNMENT}

The identification and quantification of homologous compound series (e.g. $n$-alkanes, $n$-alkanols and $n$-alkanoic acids) present in the lipid extract, associated with the application of diagnostic parameters, provides supportive data that can be used in the characterisation of emission sources. The carbon preference index (CPI) 


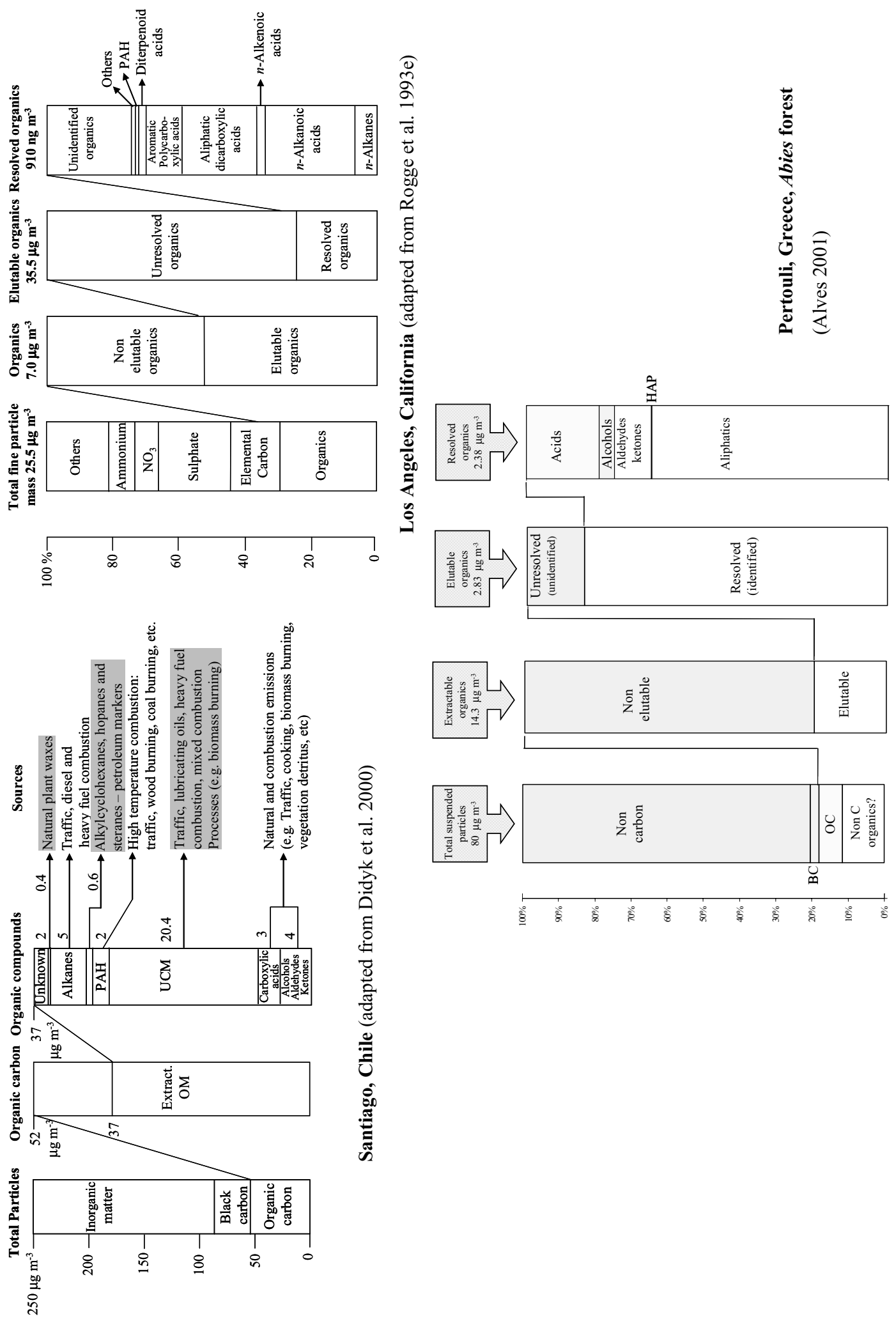

Fig. 5 - Material balances with the chemical composition of aerosols from different atmospheric environments. 
has been suggested as a qualitative tool to assess the influence of biogenic and anthropogenic inputs (Simoneit 1989). For $n$-alkanes, $n$-alkanals and $n$-alkanones this empirical parameter is expressed as a sum of the odd carbon number homologs, over a range, divided by a sum of even carbon homologs, over the same range. For $n$-alkanols and $n$-alkanoic acids CPI is calculated in a similar way, only inverting the ratio to have even-toodd homologs. Splitting the CPI range we can distinguish microbial contributions $\left(n-\mathrm{C}_{10}-n-\mathrm{C}_{24}\right)$ and higher plant wax inputs $\left(n-\mathrm{C}_{22}-n-\mathrm{C}_{34}\right)$. Thus, for $n$-alkanes, $n$-alkanals and $n$-alkanones:

CPI whole range (petroleum) $=\frac{\sum \mathrm{C}_{13}-\mathrm{C}_{35}}{\sum \mathrm{C}_{12}-\mathrm{C}_{34}}$

CPI split range (bacterial, algal) $=\frac{\sum \mathrm{C}_{11}-\mathrm{C}_{25}}{\sum \mathrm{C}_{10}-\mathrm{C}_{24}}$

CPI split range (higher plant wax) $=\frac{\sum \mathrm{C}_{27}-\mathrm{C}_{35}}{\sum \mathrm{C}_{26}-\mathrm{C}_{34}}$

For $n$-alkanols and $n$-alkanoic acids, CPI is calculated as follows:

CPI whole range (biogenic, also pyrogenic) $=\frac{\sum \mathrm{C}_{12}-\mathrm{C}_{34}}{\sum \mathrm{C}_{13}-\mathrm{C}_{35}}$

CPI split range (bacterial, some algal) $=\frac{\sum \mathrm{C}_{13}-\mathrm{C}_{35}}{\sum \mathrm{C}_{12}-\mathrm{C}_{34}}$

CPI split range (higher plant wax) $=\frac{\sum \mathrm{C}_{13}-\mathrm{C}_{35}}{\sum \mathrm{C}_{12}-\mathrm{C}_{34}}$

For biologically synthesised $n$-alkanes, an odd-to-even carbon number predominance is observed over a given carbon number range, while for $n$-alkanoic acids and $n$ alkanols an even-to-odd bias is evident. CPI values close to unity express a significant input of compounds with anthropogenic origin. A high value $(\mathrm{CPI}>3)$ indicates a major incorporation of recent biological components into the aerosol sample. Table XIII presents some results of the application of this parameter obtained for different atmospheric environments.

Since it is known that petroleum-derived $n$-alkanes have $\mathrm{CPI} \approx 1$, it is possible to subtract this contribution to determine the residual plant wax alkanes (Simoneit et al. 1991a). The concentrations of the wax $n$-alkanes are calculated by subtraction of the average of the next higher and lower even carbon numbered homologs, taking as zero the negative values of $\mathrm{C}_{n}$ :

$$
\text { Wax } \mathrm{C}_{n}=\left[\mathrm{C}_{n}\right]-\left[\frac{\mathrm{C}_{n+1}+\mathrm{C}_{n-1}}{2}\right]
$$

As stated before, $\mathrm{C}_{\max }$ can also give an indication of relative source inputs. It represents the carbon number of the compound with maximum concentration in the homologous series (Abas and Simoneit 1996, Simoneit 1989). The average chain length (ACL) is another parameter that may be used as an additional indicator of source composition, particularly for the lipid components present in the plant waxes. It is calculated as an average number of carbon atoms per molecule based on the abundance of the odd or even high homologs (Oros et al. 1999):

$$
\begin{gathered}
\text { ACL }(n \text {-alkanes }) \\
=\frac{23 \times\left[\mathrm{C}_{23}\right]+25 \times\left[\mathrm{C}_{25}\right]+27 \times\left[\mathrm{C}_{27}\right]+\cdots+35 \times\left[\mathrm{C}_{35}\right]}{\left[\mathrm{C}_{23}\right]+\left[\mathrm{C}_{25}\right]+\left[\mathrm{C}_{27}\right]+\cdots+\left[\mathrm{C}_{35}\right]} \\
=\frac{22 \times\left[C_{22}\right]+24 \times\left[C_{24}\right]+26 \times\left[C_{26}\right]+\cdots+34 \times\left[C_{34}\right]}{\left[C_{22}\right]+\left[C_{24}\right]+\left[C_{26}\right]+\cdots+\left[C_{32}\right]}
\end{gathered}
$$

It has been assumed that in warmer tropical climates longer-chain compounds are biosynthesised as wax lipids, whereas in cooler temperate regions predominantly shorter chain compounds are produced. However, certain environmental conditions, such as fog exposure, precipitation regime, aridity and growing-season temperature, may influence the plant or microbial enzymatic mechanisms, shifting the wax composition and, consequently, the aerosol constitution (Schefuß et al. 2003). The induced changes may include the cleavage and loss of one or two carbons of the long chain homologues. On the other hand, transport of air masses influenced by inputs of different taxonomic species may also play an important role (Alves et al. 2007). ACL values from 22 and 29 were found in aerosols from rural Portuguese areas, showing a significant augment by two carbon numbers with increased distance away from the coast (Alves et al. 2001). This observation may be due to taxonomic and aging differences among the emitter vegetation from place to place.

Further assessment of processes affecting the composition of hydrocarbons, such as type of vehicular emissions, wood burning, coal combustion, etc., can be obtained from concentration ratios between $\mathrm{PAH}(\mathrm{Bi}$ et al. 2002, Gogou et al. 1996, Tsapakis et al. 2002). Table XIV gathers bibliographic information on distintict 
TABLE XIII

Carbon Preference Index of $n$-alkanes for various aerosol sources.

\begin{tabular}{|c|c|c|}
\hline Aerosol type/location & CPI & Reference \\
\hline Rural Western US & $1.6-8.4$ & Simoneit (1989) \\
\hline Urban Western US & $1.2-2.8$ & Simoneit (1989) \\
\hline Oceanic aerosol: Pacific & $2-4$ & Simoneit (1989) \\
\hline Vascular Plant Wax & $6-10$ & Simoneit (1989) \\
\hline Oceanic aerosol: Atlantic & $5-10$ & Simoneit (1989) \\
\hline Natural fire smoke & $1.2-10$ & Simoneit (1989) \\
\hline Vehicular exhaust: cars & 0.93 & Simoneit (1989) \\
\hline Vehicular exhaust: diesel & 1.02 & Simoneit (1989) \\
\hline Biomass combustion, Amazonia & 3.6 & Abas et al. (1995) \\
\hline Santiago, Chile & $1.11-1.28$ & Didyk et al. (2000) \\
\hline Hong Kong & $1.2-1.9$ & Zheng et al. (2000) \\
\hline Eastern Mediterranean, urban & $1.3-1.6$ & Gogou et al. (1996) \\
\hline Eastern Mediterranean, rural & $1.6-3.3$ & Gogou et al. (1996) \\
\hline Big Bend Nacional Park, Texas & $1.2-4$ & Brown et al (2002) \\
\hline Miami, Florida, urban & $1.9 \pm 0.3$ & Lang et al. (2002) \\
\hline Guangzhou, China, urban & $1.03-1.16$ & Bi et al. (2003) \\
\hline Qinddao, China, coastal city & $1.17-5.20$ & Guo et al. (2003) \\
\hline Athens, urban & $2.70 \pm 0.30$ & Mandalakis et al. (2002) \\
\hline $\begin{array}{l}\text { Campos de Goytacares, Brazil } \\
\text { (downtown, suburbs and lagoon } \\
28 \mathrm{~km} \text { from downtown) }\end{array}$ & $0.94-3.74$ & Azevedo et al. (2002) \\
\hline Birmingham, UK, urban & $1.05-1.48$ & Harrad et al. (2003) \\
\hline $\begin{array}{l}\text { Prato, Italy, urban under influence } \\
\text { of a sewage plant and textile } \\
\text { industrial activity }\end{array}$ & $1.20 \pm 0.21$ & Cincinelli et al. (2003) \\
\hline Shanghai, urban & $1.0-1.6$ & Feng et al. (2006) \\
\hline Shanghai, rural & $1.0-2.8$ & Feng et al. (2006) \\
\hline 14 Chinese cities & $\begin{array}{c}1.17 \pm 0.14 \text { (winter) } \\
1.16 \pm 0.12 \text { (summer) }\end{array}$ & Wang et al. (2006a) \\
\hline Petrana, rural site, western Greece & $2.41 \pm 0.58$ & Kalaitzoglou et al. (2004) \\
\hline Central California & $1.7 \pm 0.3$ & Rinehart et al. (2006) \\
\hline Hyytiälä, Finland, boreal forest & $2.69 \pm 1.05$ & Alves et al. (2006) \\
\hline Melpitz, Germany, grassland & $3.09 \pm 1.38$ & Alves et al. (2006) \\
\hline Lower Fraser Valley, Canada, forest & $2.39 \pm 0.47$ & Cheng et al. (2006) \\
\hline Island of Terceira, north-eastern Atlantic & $1.61-11.34$ & Alves et al. (2007) \\
\hline
\end{tabular}

diagnostic ratios between PAH, typical values and their interpretation.

The apportionment of various solvent extractable compounds to sources may be roughly estimated by taking into consideration different contributions (Alves and Pio, in press, Simoneit et al. 1988, Tsapakis et al. 2002):

(a) Plant wax - sum of the Wax $\mathrm{C}_{n}$ concentrations for $n$-alkanes; $n$-alkanoic acids, $\mathrm{C}_{22}-\mathrm{C}_{34} ; n$-alkanols, $\mathrm{C}_{22}-\mathrm{C}_{34} ; n$-alkan-2-ones, $\mathrm{C}_{22}-\mathrm{C}_{35} ; n$-alkanals, $\mathrm{C}_{22}-\mathrm{C}_{35}$; and biogenic molecular markers such as phytosterols.

(b) Microbial components - sum of the concentrations of $n$-alkanoic acids, $\mathrm{C}_{10}-\mathrm{C}_{18}$ with CPI $>2 ; n$-alkan2-ones, $\mathrm{C}_{15}-\mathrm{C}_{21}$; and $n$-alkanols $\mathrm{C}_{12}-\mathrm{C}_{20}$. 
TABLE XIV

Diagnostic ratios between PAH reported in the literature.

\begin{tabular}{|c|c|c|c|}
\hline Ratio or Index & Value & Interpretation/Emission source & Reference \\
\hline \multirow{3}{*}{ IcdP/(BghiP+IcdP) } & 0.18 & Emissions from cars & Grimmer et al. (1983) \\
\hline & 0.37 & Diesel emissions & Grimmer et al. (1983) \\
\hline & 0.56 & Coal emissions & Grimmer et al. (1983) \\
\hline \multirow{6}{*}{$\mathrm{BaA} /(\mathrm{BaA}+\mathrm{CT})$} & $0.16 \pm 0.12$ & Crude oil emission & Sicre et al. (1987) \\
\hline & $0.38-0.64$ & Diesel cars & Sicre et al. (1987) \\
\hline & $0.22-0.55$ & Gasoline cars & Simcik et al. (1999) \\
\hline & 0.43 & Wood combustion & Li and Kamens (1993) \\
\hline & 0.28 & Cement plant & Yang et al. (1998) \\
\hline & 0.08 & Vehicle construction & Manoli et al. (2004) \\
\hline \multirow{8}{*}{$\mathrm{BeP} /(\mathrm{BeP}+\mathrm{BaP})$} & 0.50 & $\begin{array}{l}\text { Freshy emitted PAH. This ratio is affected by } \\
\text { the strong reactivity in the atmosphere since } \mathrm{BaP} \text { is } \\
\text { easily decomposed by light and oxidants. Most of the } \\
\text { fresh exhausts have similar contents of } \mathrm{BeP} \text { and } \mathrm{BaP} \text {, } \\
\text { thus the increasing of the ratio can be regarded as } \\
\text { an index of the aging of particles. }\end{array}$ & Grimmer et al. (1983) \\
\hline & 0.70 & Diesel cars & Rogge et al. (1993d) \\
\hline & $0.60-0.80$ & Gasoline cars & Rogge et al. (1993d) \\
\hline & 0.34 & Wood & Li and Kamens (1993) \\
\hline & 0.54 & Road dust & Rogge et al. (1993a) \\
\hline & 0.45 & Roadway soil & Oda et al. (2001) \\
\hline & $0.85-0.94$ & Vehicle construction & Manoli et al. (2004) \\
\hline & $0.90-0.99$ & Fertilizer production & Manoli et al. (2004) \\
\hline \multirow{9}{*}{$\mathrm{Flu} /(\mathrm{Flu}+\mathrm{Pyr})$} & 0.44 & Catalytic automobiles & Rogge et al. (1993d) \\
\hline & $<0.40$ & Car emissions and used motor or lubricating oils & Azevedo et al. (1999) \\
\hline & $0.60-0.70$ & Diesel cars & Sicre et al. (1987) \\
\hline & 0.40 & Gasoline cars & Rogge et al. (1993d) \\
\hline & 0.42 & Road dust & Rogge et al. (1993a) \\
\hline & 0.54 & Roadway soil & Oda et al. (2001) \\
\hline & $0.21-0.26$ & Industrial & Yang et al. (1998) \\
\hline & 0.25 & Cement plant & Yang et al. (1998) \\
\hline & 0.45 & Metal scrap burn & Tsai et al. (1995) \\
\hline \multirow{8}{*}{$\mathrm{IcdP} /(\mathrm{BghiP}+\mathrm{IcdP})$} & $0.21-0.22$ & Gasoline cars & Khalili et al. (1995) \\
\hline & $0.35-0.70$ & Diesel emissions & Rogge et al. (1993d) \\
\hline & 0.56 & Coal emissions & Grimmer et al. 1983 \\
\hline & 0.62 & Wood burning & $\begin{array}{l}\text { Gogou et al. (1996), } \\
\text { Sicre et al. (1987) }\end{array}$ \\
\hline & 0.36 & Road dust & Rogge et al. (1993a) \\
\hline & 0.42 & Roadway soil & Oda et al. (2001) \\
\hline & $0.36-0.57$ & Industrial & Yang et al. (1998) \\
\hline & 0.65 & Cement plant & Yang et al. (1998) \\
\hline BghiP/BeP & & $\begin{array}{l}\text { Indicator for traffic, with higher ratios indicating } \\
\text { a higher traffic contribution }\end{array}$ & Nielson et al. (1996) \\
\hline \multirow{8}{*}{ BghiP/BaP } & $1.2-2.2$ & Diesel cars & Rogge et al. (1993d) \\
\hline & $2.5-3.3$ & Gasoline cars & Rogge et al. (1993d) \\
\hline & $<0.5$ & Oil burning & Simcik et al. (1999) \\
\hline & 0.91 & Road dust & Rogge et al. (1993a) \\
\hline & 0.86 & Roadway soil & Oda et al. (2001) \\
\hline & $0.02-0.06$ & Industrial & Yang et al (1998) \\
\hline & 0.06 & Cement plant & Yang et al (1998) \\
\hline & 0.09 & Metal scrap burn & Tsai et al. (1995) \\
\hline
\end{tabular}


TABLE XIV (continuation)

\begin{tabular}{|c|c|c|c|}
\hline Ratio or Index & Value & Interpretation/Emission source & Reference \\
\hline \multirow{5}{*}{$\mathrm{CPAH} / \Sigma \mathrm{PAH}$} & 0.41 & Emissions from non-catalyst-equipped automobiles & Rogge et al. (1993d) \\
\hline & 0.51 & Emissions from catalyst-equipped automobiles & Rogge et al. (1993d) \\
\hline & 0.30 & Emissions from heavy-duty diesel trucks & Rogge et al. (1993d) \\
\hline & $>0.50$ & $\begin{array}{l}\text { Ferrous metal electroplating, steel manufacture, } \\
\text { fertilizer production, and asphalt emissions }\end{array}$ & Monoli et al. (2004) \\
\hline & 0.48 & Metal scrap burn & Tsai et al. (1995) \\
\hline \multirow{7}{*}{$\mathrm{MPh} / \mathrm{Ph}$} & $1-8$ & $\begin{array}{l}\text { Represent evidence for enhanced mobile sources or } \\
\text { unburned fossil organic material contribution }\end{array}$ & Gogou et al. (1996) \\
\hline & $<1$ & $\begin{array}{l}\text { Typical of emissions from stationary sources where } \\
\text { fuel is burning at higher temperatures }\end{array}$ & Gogou et al. (1996) \\
\hline & 0.5 & Atmospheric fallout & Takada et al. (1991) \\
\hline & $0.5-1.0$ & Combustion sources & Prahl and Carpenter (1983) \\
\hline & 1.0 & Street and urban dusts & Takada et al. $(1990,1991)$ \\
\hline & $2.0-6.0$ & Fossil fuel & Prahl and Carpenter (1983) \\
\hline & 4.0 & Crankcase oil & Pruel and Quinn (1988) \\
\hline \multirow{8}{*}{$\mathrm{BFs} / \mathrm{BghiP}$} & 1.60 & Diesel cars & Li and Kamens (1993) \\
\hline & 0.33 & Gasoline cars & Li and Kamens (1993) \\
\hline & 2.18 & Wood & Li and Kamens (1993) \\
\hline & 4.7 & Road dust & Rogge et al. (1993a) \\
\hline & 1.8 & Roadway soil & Oda et al. (2001) \\
\hline & $7.1-11.2$ & Industrial & Yang et al. (1998) \\
\hline & 7.8 & Cement plant & Yang et al. (1998) \\
\hline & 4.0 & Metal scrap burn & Tsai et al. (1995) \\
\hline$\alpha$ & $3 \times 10^{-4}-40 \times 10^{-4}$ & Common emission sources for PAH and BC & Blanchard et al. (1994) \\
\hline $\mathrm{BaPE}$ & & $\begin{array}{l}\text { Index that has been introduced instead of the sole } \\
\text { BaP since the later is easily decomposed in reactive } \\
\text { air. It tries to parameterise the health risk for } \\
\text { humans related to ambient PAH exposition and is } \\
\text { calculated by multiplying the concentrations of } \\
\text { each carcinogenic congener. Exposition to a } \\
\text { significant cancer risk if values exceed } 1.0 \mathrm{ng} \mathrm{m}^{-3} \text {. }\end{array}$ & $\begin{array}{l}\text { Cecinato et al. (1998), } \\
\text { Marino et al. (2000), } \\
\text { Yassaa et al. (2001b) }\end{array}$ \\
\hline
\end{tabular}

BaA - Benzo[a]anthracene; CT - Crysene and Tryphenylene; BeP - Benzo[e]pyrene; BaP - Benzo[a]pyrene; Flu - Fluoranthene; Pyr - Pyrene; IcdP - Indeno[1,2,3-cd]pyrene; BghiP - Benzo[ghi]perylene; CPAH - nine combustion PAH (Fluoranthene, Pyrene, Benzo[a]anthracene, Crysene, Benzofluoranthenes, Benzo[e]pyrene, Benzo[a]pyrene, Indeno[1,2,3-cd]pyrene] and Benzo[ghi]perylene); $\Sigma \mathrm{PAH}$ - total concentration of PAH; MPh - Methylphenanthrenes; Ph- Phenanthrene; BFs = Benzofluoranthenes; $\alpha=\Sigma \mathrm{PAH} / \mathrm{BC}$; BaPE - Benzo[a]pyrene-equivalent carcinogenic power $=\mathrm{BaPE}=\mathrm{BaA} \times 0.06+\mathrm{BFs} \times 0.07+\mathrm{BaP}+\mathrm{DBA} \times$ $0.6+\mathrm{IcdP} \times 0.08 ; \mathrm{DBA}=$ Dibenzo[a,h]anthracene

(c) Thermally maturated and pyrogenic components sum of the concentrations of anthropogenic $n$-alkanes (Total $\mathrm{C}_{n}-$ Wax $\mathrm{C}_{n}$ ) and the corresponding unresolved complex mixture; $n$-alkanoic acids, $\mathrm{C}_{10}-\mathrm{C}_{18}$, with $\mathrm{CPI}<1.5$; alkylcyclohexanes; alkylcylopentanes; hopanes; steranes; diasteranes; pristane; phytane; ketones and aldehydes with CPI $<1.5$; biomass burning tracers and PAH.

To exemplify the application of this methodology, the different source groups contributing to the aerosol constitution in different locations are plotted in Figure 6. Surprisingly, high relative concentrations of biomass smoke and petrogenic constituents in organic matter were observed for wintry conditions at European continental low level sites (Moitinhos and K-Puszta). This indicates the transport from urban emissions in the vicinities and a sizable impact of domestic biomass burning on air quality. The contribution of petroleum residues and other thermally produced constituents at these non-urban European sites is comparable to those reported for Asiatic urban and suburban aerosols. The lipid wax components 
ranged from a minimum of $17 \%$ in Hong Kong to a maximum of $83 \%$ in rural Nigeria of the apportioned organic mass. The fractions of microbial components for European sites are of the same order than those of the Nigerian rural aerosol, but one-half lower than the one estimated for the Amazon particulate matter.

\section{CONCLUSIONS AND RECOMMENDATIONS}

Various studies on the composition of atmospheric particulate matter revealed that a significant fraction of the total mass could be attributed to organic constituents. Despite its abundance, the role of the organic aerosol as a substrate for chemical reactions is not well understood. Due to the large variety of organic functional groups at the particle surface they are possible reactants for many chemical processes with gaseous molecules in the troposphere. The difficulties in characterising the large variety of compounds present are still aggravated, because this study represents a complicated, time-consuming and expensive process. Much of the research to date has focused upon urban areas, where organic emissions are large and have dramatic effects on air quality and particulate mass concentrations. More pristine environments, especially forests where VOC emissions are large and potential contributors to SOA, remain poorly characterised. Assessment of natural versus anthropogenic and of primary versus secondary organic contributions to aerosol in non-urban regions represents an important research area, since very little is known about these environments.

Usually, $n$-alkanes and aliphatic acids constitute the dominant solvent-extractable components of the atmospheric particulate matter. Smaller quantities of alcohols, aldehydes, ketones, terpenoids and PAH are also observed. These constituents are emitted directly from biogenic sources (vascular plant wax, microorganisms, pollen, etc.) or derive from anthropogenic activities (vehicular emissions, wood combustion, etc.). The aerosol compounds that are formed by direct oxidation from volatile organic precursors are also detected in the particulate matter, representing a fraction of the total chromatographycally resolved organic mass. Molecular marker techniques can be used to identify contributions of sources such as combustion and biogenic emissions. However, source apportionment strategies will still need the challenge of truthfully determining the concentration of SOA in the particulate phase. Additional field studies are required in locations that are impacted by SOA deriving from both biogenic and anthropogenic sources. Although quantitative collection of both semi-volatile and particulate phase organic compounds is enviable, the existing sampling equipment is not capable of efficiently collect compounds with lower vapour pressures. Also, further smog chamber experiments will be usefull in providing information on stability of potential tracers for SOA and atmospheric reactions. Moreover, these experiments will constitute an opportunity to test more advanced analytical techniques, to model the fate of the secondary aerosol from precursor to sink, and to perform an integration of experimental procedures among field campaigns, primary source measurements and laboratory studies. It seems important to evaluate the methods in use for measuring secondary aerosol components.

One of the most important goals associated with the detailed chemical analysis of organic aerosols consists of mass balances relating gravimetric measures, carbonaceous content and organic compound classes. Until now the scientific investigation did not allow to close these mass balances because of the difficulties in extracting and measure some complex constituents by conventional methods. Recent results on water-soluble organic carbon supplement data of previous studies, but the overall understanding of the organic aerosol remains relatively obscure. New approaches for the chemical analysis of the organic aerosol based on a combination of solvent and water extractions, preparatory separations into different functional groups and efficient instrumental determination will give a more clear insight into the origin and formation processes of primary and secondary carbonaceous particles. Once more, it should be recognised the necessity of future work to assess the overall organic composition of atmospheric aerosols, including their hydrophilic constituents, and to develop more efficient analytical equipments able to discriminate the carbonaceous content.

Accurate quantification of the amounts of trace gases and particulate matter emitted from forest fires and other sources of biomass burning on a regional and global basis is required by a number of users, including scientists studying a wide range of atmospheric pro- 


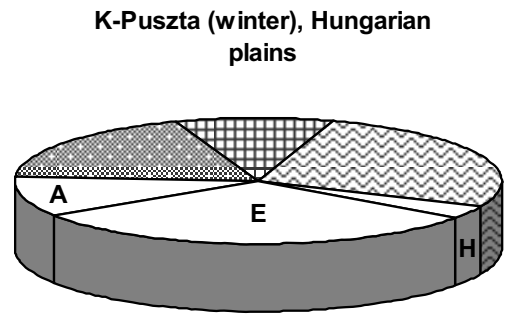

$293 \mathrm{ng} \mathrm{m}^{-3}$

(Oliveira et al. 2007c)

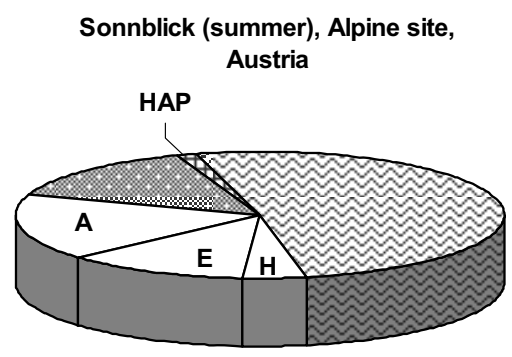

$45 \mathrm{ng} \mathrm{m}^{-3}$

(Oliveira et al. 2007c)

Azores (summer), Atlantic

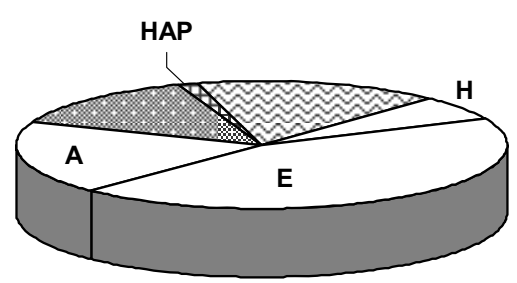

$15 \mathrm{ng} \mathrm{m}^{-3}$

(Oliveira et al. 2007c)

Amazonia

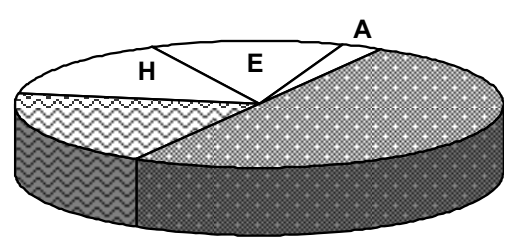

1.3-3.8 $\mu \mathrm{g} \mathrm{m}^{-3}$

(Simoneit et al. 1990)

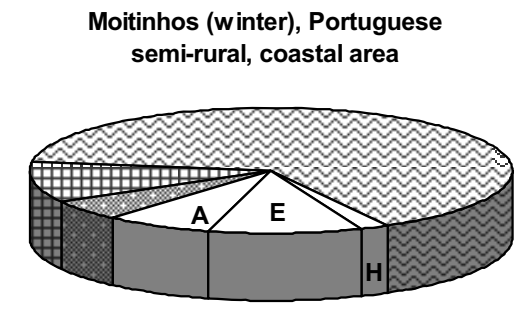

$237 \mathrm{ng} \mathrm{m}^{-3}$

(Oliveira et al. 2007c)

Pertouli, Greece, forest

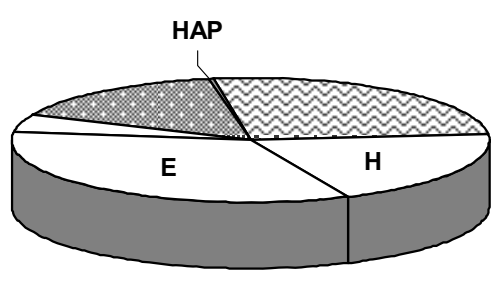

$1359 \mathrm{ng} \mathrm{m}^{-3}$

(Alves and Pio, in press)

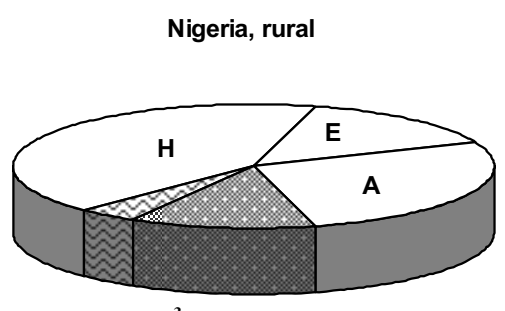

$0.7-2.4 \mu \mathrm{g} \mathrm{m}^{-3}$

(Simoneit et al. 1988)

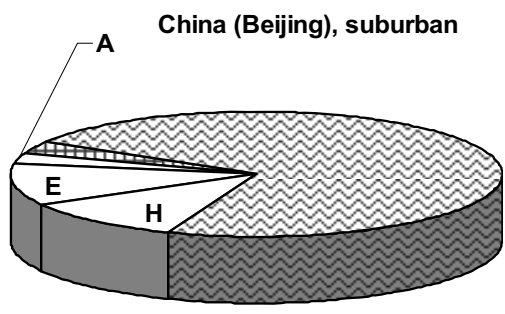

$1.2 \mu \mathrm{g} \mathrm{m}^{-3}$

(Simoneit et al. 1991a)
Schauinsland (summer), Germany, forested highlands

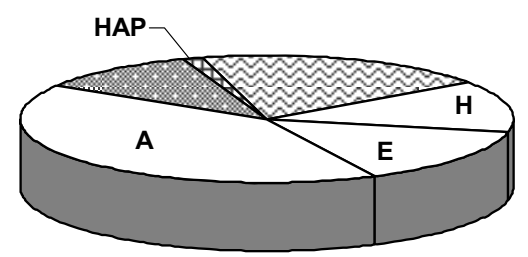

$72 \mathrm{ng} \mathrm{m}^{-3}$

(Oliveira et al. 2007c)

Giesta, Portugal, summer, rural

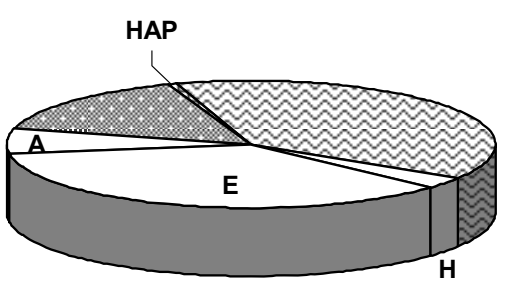

$1356 \mathrm{ng} \mathrm{m}^{-3}$

(Alves and Pio, in press)

Hong Kong (Kwai Chung), urban

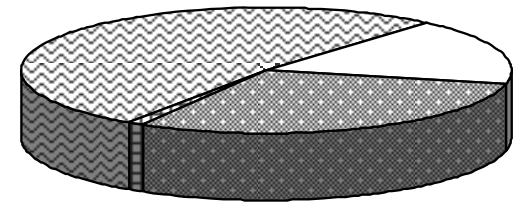

$468 \mathrm{ng} \mathrm{m}^{-3}$

(Zheng et al. 1997)

Fig. 6 - Pie diagrams showing the apportionment of various lipid fractions to sources in various regions of the word.

cesses, national governments who are required to report greenhouse gas emissions, and those interested quantifying the sources of air pollution that affect human health at regional scales. In Europe and other parts of the world, data on detailed emission factors from biomass burning are rather inexistent. Emission inventories and source apportionment, photochemistry and climate change models use default values obtained for US biofuels, uncommon 
in other countries. Thus, it is desirable to use more specific locally available data.

In spite of comparisons between sites being difficult due to the lack of harmonisation in sampling and analytical techniques, it would be advantageous the compilation of existing results in a freely accessible scientific database. The assessment of the variability of aerosol in space and time would permit a better understanding of their sources, properties, atmospheric behaviour and effects. Also, it would help evaluate the representation of aerosols in chemical transport and climate models.

\section{ACKNOWLEDGMENTS}

I am grateful to Prof. Casimiro Pio, from the University of Aveiro, Portugal, for many helpful discussions. Additional thanks are given to the Centre for Environmental and Marine Studies (CESAM), of the same university, for supporting this work.

\section{RESUMO}

Apesar de constituirem $10-70 \%$ da massa do aerosol atmosférico, a caracterização dos compostos orgânicos particulados permanece ainda deficitária e vários aspectos relativos à formação e evolução do aerossol são ainda desconhecidos. A crescente preocupação com o impacto do aerosol particulado no clima e os reconhecidos efeitos dos constituintes antropogênicos na qualidade do ar e na saúde humana têm motivado a realização de numerosos estudos. Estas investigações têm fornecido informações relevantes sobre o comportamento da matéria particulada na atmosfera e sobre o seu conteúdo carbonáceo. A compilação de tais resultados reveste-se da maior importância, dado que possibilitará coligí-los numa ainda emergente base de dados global sobre a composição orgânica dos aerossóis. A contribuição das principais fontes de emissão para a poluição particulada a nível regional pode ser diagnosticada através da utilização de marcadores moleculares específicos. Esta revisão foca sobretudo os resultados obtidos por cromatografia gasosa acoplada a espectrometria de massa, dado que é o método analítico de eleição para a clarificação dos compostos orgânicos extratíveis por solventes presentes na matéria particulada atmosférica. Uma sinópse da selecção de compostos traçadores e da aplicação de parâmetros geoquímicos à análise dos constituintes orgânicos como ferramenta para estimar a contribuição das diversas fontes é aqui apresentada. Além de uma avaliação do conhecimento atual, o artigo iden- tifica também as necessidades de investigações futuras.

Palavras-chave: aerossol atmosférico, cromatografia gasosaespectrometria de massa, compostos orgânicos, fontes contributivas, traçadores.

\section{REFERENCES}

AbAs MRB And Simoneit BRT. 1996. Composition of extractable organic matter of air particles from Malaysia: initial study. Atmos Environ 15: 2779-2793.

ABAS MRB AND SimONEIT BRT. 1997. Gas chromatographic and gas chromatographic-mass spectrometric characterization of biogenic and petrogenic organic matter in the atmosphere. Malaysian J Anal Sci 3: 9-23.

Abas MrB, Simoneit BRT, Elias V, Cabral JA And CARdoso JN. 1995. Composition of higher molecular weight organic matter in smoke aerosol from biomass combustion in Amazonia. Chemosphere 30: 995-1015.

Abas MRB, Oros DR AND SimoneIt BRT. 2004a. Biomass burning as the main source of organic aerosol particulate matter in Malaysia during haze episodes. Chemosphere 55: 1089-1095.

ABAs MRB, RAHMAN NA, OMAR NYMJ, MAAH MJ, SAMAH AA, Oros DR, OtTo A AND SimoneIt BRT. 2004b. Organic composition of aerosol particulate matter during a haze episode in Kuala Lumpur, Malaysia. Atmos Environ 38: 4223-4241.

ABELSON PH. 1998. Airborne particulate matter. Science 281: 1609 .

Aceves M and GRImalt JO. 1992. Gas chromatographic screening of organic compounds in urban aerosols. J Chromatogr 607: 261-270.

ACeves M And Grimalt JO. 1993. Gas chromatographic screening of organic compounds in urban aerosols. II. Changes in hydrocarbon composition during storage. J Chromatogr 655: 133-140.

Alves C. 2001. Origin and composition of organic matter present in atmospheric aerosols, PhD Thesis, University of Aveiro, Portugal.

Alves C And Pio C. 2005. Secondary organic compounds in atmospheric aerosols: speciation and formation mechanisms. J Braz Chem Soc 16: 1017-1029.

Alves C AND Pio C. in press. Molecular markers, essential oils and diagnostic parameters as indicators for assessing the origin and constitution of organic matter in atmospheric aerosols. Int J Environ Pollut.

Alves C, Pio C and Duarte A. 2000. Particulate size dis- 
tributed organic compounds in a forest atmosphere. Environ Sci Technol 34: 4287-4293.

Alves C, Pio C and Duarte A. 2001. Composition of extractable organic matter of air particles from rural and urban Portuguese areas. Atmos Environ 35: 5485-5496.

Alves C, Carvalho A And Pio C. 2002. Mass balance of organic carbon fractions in atmospheric aerosols. J Geophys Res 107(D21): 8345-8353.

Alves C, Pio C, Carvalho A and Santos C. 2006. Atmospheric carbonaceous aerosols over grasslands of central Europe and a Boreal forest. Chemosphere 63: 153-164.

Alves C, Oliveira T, Pio C, Silvestre AJd, Fialho P, BARATA F AND LEgRAND M. 2007. Characterisation of carbonaceous aerosols from the Azorean Island of Terceira. Atmos Environ 41: 1359-1373.

AREy J, Zielinska B, AtKinson R And Winer AM. 1987. Polycyclic aromatic hydrocarbons and nitroarene concentration in ambient air during a wintertime high $\mathrm{NO}_{\mathrm{x}}$ episode in the Los Angeles basin. Atmos Environ 21: 1437-1444.

ATKINSON R. 1990. Gas-phase tropospheric chemistry of organic compounds: a review. Atmos Environ 24A: 1-41.

ATKINSON R AND AREY J. 1994. Atmospheric chemistry of gas-phase polycyclic aromatic hydrocarbons: Formation of atmospheric mutagens. Environ Health Perspect 102 (Suppl 4): 117-126.

Azevedo DA, Moreira LS ANd Siqueira DS. 1999. Composition of extractable organic matter in aerosols from urban areas of Rio de Janeiro city, Brazil. Atmos Environ 33: 4987-5001.

Azevedo DAS, Santos CYM and Neto FRA. 2002. Identification and seasonal variation of atmospheric organic pollutants in Campos dos Goytacazes, Brazil. Atmos Environ 36: 2383-2395.

BAek SO, Field RA, Goldstone ME, Kirk PW, LESTER JN AND PERRY R. 1991. A review of atmospheric polycyclic aromatic hydrocarbons: sources, fate and behavior. Water Air Soil Poll 60: 279-300.

Baldasano JM, Valera E and Jimémez P. 2003. Air quality data from large cities. Sci Total Environ 307: 141165.

BAMFORD HA AND BAKER JE. 2003. Nitro-polycyclic aromatic hydrocarbon concentrations and sources in urban and suburban atmospheres of the Mid-Atlantic region. Atmos Environ 37: 2077-2091.

Bamford HA, BeZabeh DZ, Schantz MM, Wise SA
AND BAKER JE. 2003. Determination and comparison of nitrated-polycyclic hydrocarbons measured in air and diesel particulate reference materials. Chemosphere 50: 575-587.

BARKenbus BD, Griest WH, Huntzicker JJ, HeyerDAHL EK AND MacDougall CS. 1983a. Recovery of organic carbon from atmospheric particulate matter using Soxhlet extraction with benzene/methanol azeotrope. Environ Sci Health A18: 297-310.

Barkenbus BD, MacDougall C, Griest WH AND CATON JE. 1983b. Methodology for the extraction and analysis of hydrocarbons and carboxylic acids in atmospheric particulate matter. Atmos Environ 17: 15371543.

Becker G, Colmsjö A And Östman C. 1999. Determination of thiarenes and polycyclic aromatic hydrocarbons in workplace air of an aluminum reduction plant. Environ Sci Technol 33: 1321-1327.

Besombes Jl, Maître A, Patissier O, Marchand N, Chevron N, Stoklov M and Masclet P. 2001. Particulate PAHs in the surrounding of a municipal incinerator. Atmos Environ 35: 6093-6104.

Bezabeh DZ, Jones AD, Ashbaugh LL and Kelly PB. 1999. Screening of aerosol filter samples for PAHs and nitro-PAHs by laser desorption ionization TOF mass spectrometry. Aerosol Sci Technol 30: 288-299.

Bhat S AND Fraser MP. 2007. Primary source attribution and analysis of $\alpha$-pinene photooxidation products in Duke Forest, North Carolina. Atmos Environ. 41: 2958-2966.

Bi X, Sheng G, Peng P, Zhang Z and Fu J. 2002. Extractable organic matter in $\mathrm{PM}_{10}$ from LiWan district of Guangzhou City, PR China. Sci Total Environ 300: 213-228.

Bi X, Sheng G, Peng P, Chen Y, Zhang Z and Fu J. 2003. Distribution of particulate- and vapour-phase $n$ alkanes and polycyclic aromatic hydrocarbons in urban atmosphere of Guangzhou, China. Atmos Environ 37: 289-298.

BIRCH ME. 1998. Analysis of carbonaceous aerosols: interlaboratory comparison. Analyst 123: 851-857.

BIRCH ME AND CARY RA. 1996. Elemental carbon-based method for monitoring occupational exposures to particulate diesel exhaust. Aerosol Sci Technol 25: 221-241.

Blanchard P, Hopper JF AND BARrie LA. 1994. GCMS analysis of thermally desorbed organic aerosol constituents collected at Canadian global baseline monitoring stations. Fifth International Conference on Carbonaceous Particles in the Atmosphere. Berkeley, CA, USA. 
BLANChARD P, BRoOK JR AND BRAZAL P. 2002. Chemical characterization of the organic fraction of atmospheric aerosol at two sites in Ontario, Canada. J Geophys Res 107: 8348, ICC 10-1,10-8. doi: 10.1029/2001JD000627.

Böge O, Miao Y, Plewka A and Herrmann H. 2006. Formation of secondary organic phase compounds from isoprene gas-phase oxidation products: An aerosol chamber and field study. Atmos Environ 40: 2501-2509.

Boon KF, Kiefert L and McTainsh GH. 1998. Organic matter content of rural dusts in Australia. Atmos Environ 32: $2817-2823$.

Brandenberger S, Mohr M, Grob K and Neukom HP. 2005. Contribution of unburned lubricating oil and diesel fuel to particulate emission from passenger cars. Atmos Environ 39: 6985-6994.

Brown JR, Field RA, Goldstone ME, Lester JN AND PERRY R. 1996. Polycyclic aromatic hydrocarbons in central London air during 1991 and 1992. Sci Total Environ 177: 73-84.

Brown S, Herckes P, Ashbaugh L, Hannigan M, Kreidenweis S And Collett JR J. 2002. Characterization of organic aerosol in Big Bend National Park, Texas. Atmos Environ 36: 5807-5818.

Cadle SH and Mulawa PA. 1990. Atmospheric carbonaceous species measurement methods comparison study: General Motors results. Aerosol Sci Technol 12: 128141.

Cahill TM, Seaman VY, Charles MJ, Holzinger R AND GOLDSTEIN AH. 2006. Secondary organic aerosols formed from oxidation of biogenic volatile organic compounds in Sierra Nevada Mountains of California. J Geophys Res 111(D16312), doi:10.1029/2006JD007178.

Calhoun DD, Salmon LG, Schauer JJ And ChristoFOROU CS. 2003. $\mathrm{PM}_{2.5}$ characterization and sourcereceptor relations in South Carolina. J Environ Eng Sci 2: 441-451.

Calogirou A, Duane M, Kotzias D, Lahaniati M AND LARSEN BR. 1997. Polyphenylenesulfide noxon ${ }^{\circledR}$, an ozone scavenger for the analysis of oxygenated terpenes in air. Atmos Environ 31: 2741-2751.

Cancio Jal, Castellano AV, Santana Martín SS AND RODRÍGUEZ JFS. 2004. Size distributions of PAHs in ambient air particles of two areas of Las Palmas de Gran Canaria. Water, Air, Soil Poll 154: 127-138.

CaO J, Lee SC, Ho KF, Zou SC, Fung K, Li Y, Watson JG AND CHOw JC. 2004. Spatial and seasonal variations of atmospheric organic carbon and elemental carbon in Pearl River Delta Region, China. Atmos Environ 38: 4447-4456.

CaO JJ, Lee SC, Ho KF, Zhang XY, Zou SC, Fung K, ChOW JC And WATson JG. 2003. Characteristics of carbonaceous aerosol in Pearl River Delta Region, China during 2001 winter period. Atmos Environ 37: $1451-1460$

Carvalho A, Pio A And Santos C. 2003. Water-soluble hydroxylated organic compounds in German and Finnish aerosols. Atmos Environ 37: 1775-1783.

Carvalho A, Pio C, Santos C and Alves C. 2006. Particulate carbon in the atmosphere of a Finnish forest and a German anthropogenically influenced grassland. Atmos Res 80: 133-150.

CASS GR. 1998. Organic molecular tracers for particulate air pollution sources. Trends Anal Chem 17: 356-365.

Cautreels W and Cauwenberghe KV. 1977. Fast quantitative analysis of organic compounds in airborne particulate matter by gas chromatography with selective mass spectrometric detection. J Chromatogr 131: 253-264.

Cecinato A, Ciccioli P, Brancaleoni E and Zagari M. 1998. PAH and N-PAH in the urban atmosphere of Rome and Milan. Ann Chim Rome 88: 369-379.

CHEN X AND Simoneit BRT. 1994. Epicuticular waxes from vascular plants and particles in the lower troposphere: analysis of lipid classes by iatroscan thin-layer chromatography with flame ionization detection. J Atmos Chem 18: 17-31.

Cheng Y, Li SM, Leithead A, Brickell PC AND LEAITCH WR. 2004. Characterizations of cis-pinonic acid and $n$-fatty acids on fine aerosols in the Lower Fraser Valley during Pacific 2001 Air Quality Study. Atmos Environ 38: 5789-5800.

Cheng Y, Li SM, Leithead A and Brook JR. 2006. Spatial and diurnal distributions of $n$-alkanes and $n$-alkan2-ones on $\mathrm{PM}_{2.5}$ aerosols in the Lower Fraser Valley, Canada. Atmos Environ 40: 2706-2720.

Cho AK ET AL. 2004. Determination of four quinones in diesel exhaust particles, SRM 1649a and atmospheric $\mathrm{PM}_{2.5}$. Aerosol Sci Technol 38 (Suppl 1): 68-81.

ChOw JC And Watson JG. 2002. Review of $\mathrm{PM}_{2.5}$ and $\mathrm{PM}_{10}$ Apportionment for fossil fuel combustion and other sources by the chemical mass balance receptor model. Energy Fuels 16: 222-260.

Chow JC, Watson JG, Pritchett LC, Pierson LR, Frazier CA AND Purcell RG. 1993. The DRI thermal/optical reflectance carbon analysis system: descrip- 
tion, evaluation and applications in U.S. air quality studies. Atmos Environ 27A: 1185-1201.

Chow JC, Watson JG, Crow D, Lowenthal DH and Merrifield T. 2001. Comparison of IMPROVE and NIOSH carbon measurements. Aerosol Sci Technol 34: 23-34.

Chow JC, Watson JG, Chen LWA, Arnott WP, MoosMÜLLER H AND FUNG K. 2004. Equivalence of elemental carbon by thermal/optical reflectance and transmittance with different temperature protocols. Environ Sci Technol 38: 4414-4422.

Chow JC, Watson JG, Chen LWA, Paredes-Miranda G, Chang MCO, Trimble D, Fung KK, Zhang H AND YU JZ. 2005. Refining temperature measures in thermal/optical carbon analysis. Atmos Chem Phys 5: 2961-2972.

Christoffersen TS et AL. 1998. cis-Pinic acid, a possible precursor for organic aerosol formation from ozonolysis of $\alpha$-pinene. Atmos Environ 32: 1657-1661.

Chuang JC, Mack GA, Kuhlman MR and Wilson NK. 1991. Polycyclic aromatic hydrocarbons and their derivatives in indoor and outdoor air in an eight-home study. Atmos Environ 25B: 369-380.

Ciccioli P, Cecinato A, Brancaleoni E, Frattoni M AND ZACCHEI P. 1996. Formation and transport of 2-nitrofluoranthene and 2-nitropyrene of photochemical origin in the troposphere. J Geophys Res 101: 19567 19581.

Cincinelli A, Mandorlo S, Dickhut RM ANd LePri L. 2003. Particulate organic compounds in the atmosphere surrounding an industrialised area of Prato (Italy). Atmos Environ 37: 3125-3133.

Cincinelli A, Bubba M, Martellini T, Gambaro A AND LEPRI L. 2007. Gas-particle concentration and distribution of $n$-alkanes and polycyclic aromatic hydrocarbons in the atmosphere of Prato (Italy). Chemosphere 68: $472-478$.

Claeys M ET AL. 2004a. Formation of secondary organic aerosols through photooxidation of isoprene. Science 303: 1173-1176.

Claeys M, Wang W, Ion AC, Kourtchev I, GelencSer A And Maenhaut W. 2004b. Formation of secondary organic aerosols from isoprene and its gas-phase oxidation products through reaction with hydrogen peroxide. Atmos Environ 38: 4093-4098.

Claeys M et AL. 2007. Hydroxydicarboxylic acids: markers for secondary organic aerosol from the photooxidation of $\alpha$-pinene. Environ Sci Technol 41: 1628-1634.
Clements AL and Seinfeld JH. 2007. Detection and quantification of 2-methyltetrols in ambient aerosol in the southeastern United States. Atmos Environ 41: 18251830.

Conde FJ, Ayala JH, Afonso AM and González V. 2004. Optimization of a sampling meted to determine polycyclic aromatic hydrocarbons in smoke from incomplete biomass combustion. Anal Chim Acta. 524: 287294.

Conny JM, KLinedinst DB, Wight SA And PAUlsen JL. 2003. Optimizing thermal-optical methods for measuring atmospheric elemental (black) carbon: A response surface study. Aerosol Sci Technol 37: 703-723.

CONTE MH AND WEBER JC. 2002. Long-range atmospheric transport of terrestrial biomarkers to the western North Atlantic. Global Biogeochem Cycles 16: 1142, doi:10.1029/ 2002GB001922.

Cooper DA, Peterson K and Simpson D. 1996. Hydrocarbon, PAH and PCB emissions from ferries: a case study in the Skagerak-Kattegatt-öresund region. Atmos Environ 30: 2463-2473.

Creutznacher H, Löffler F, Tscheschel A AND VeITH A. 2003. Querempfindlichkeit gegen Stickstoffdioxid und Ozon bei der Immissionsmessung von schwebstaubakkumuliertem benzo(a)pyren und weiteren PAK. UMEG 2003. Available from: < http://www.umeg.de/ analysen/immission_ozon_benzoapyren_2003.pdf $>$.

CRIMMINS BS AND BAKER JE. 2006. Improved GC/MS methods for measuring hourly $\mathrm{PAH}$ and nitro-PAH concentrations in urban particulate matter. Atmos Environ 40: 6764-6779.

Decesari S, Facchini MC, Fuzzi S And Tagliavini E. 2000. Characterization of water-soluble organic compounds in atmospheric aerosol: A new approach. J Geophys Res 105: 1491-1489.

Decesari S, Facchini MC, Matta E, Lettini F, Mircea M, Fuzzi S, TAgliavini E And Putaud JP. 2001. Chemical features and seasonal variation of fine aerosol water-soluble organic compounds in the Po Valley, Italy. Atmos Environ 35: 3691-3699.

Didyk BM, Simoneit BRT, PezoA AL, Riveros LM AND Flores A. 2000. Urban aerosol particles of Santiago, Chile: organic content and molecular characterization. Atmos Environ 34: 1167-1179.

DimashKi M, HARRAd S AND HARrison RM. 2000. Measurement of nitro-PAH in the atmospheres of two cities. Atmos Environ 34: 2459-2469. 
DINGENEN R ET AL. 2004. European aerosol phenomenology-1: physical characteristics of particulate matter at kerbside, urban, rural and background sites in Europe. Atmos Environ 38: 2561-2577.

DUAN F, LIU X, YU T AND CACHIER H. 2004. Identification and estimate of biomass burning contribution to the urban aerosol organic carbon concentrations in Beijing. Atmos Environ 38: 1275-1282.

DYremark A, Westerholm R, ÖVERIK E AND GUSTAVSSON JA. 1995. Polycyclic aromatic hydrocarbons (PAH) emissions from charcoal grilling. Atmos Environ 29: $1553-1558$.

Edney EO, Kleindienst TE, CONVER TS, McIVer CD, Corse EW AND Weathers WS. 2003. Polar organic oxygenates in $\mathrm{PM}_{2.5}$ at a southeastern site in the United States. Atmos Environ 37: 3947-3965.

Edney EO, Kleindienst TE, Jaoui M, Lewandowski M, Offenberg JH, Wang W and Claeys M. 2005. Formation of 2-methyl tetrols and 2-methylglyceric acid in secondary organic aerosol from laboratory irradiated isoprese $/ \mathrm{NO}_{\mathrm{x}} / \mathrm{SO}_{2} /$ air mixtures and their detection in ambient $\mathrm{PM}_{2.5}$ samples collected in the eastern United States. Atmos Environ 39: 5281-5289.

Edye LA AND Richards GN. 1991. Analysis of condensates from wood smoke: components derived from polysaccharides and lignins. Environ Sci Technol 25: 1133-1137.

Elias Vo, Simoneit BRT, Pereira AS and Cardoso JN. 1997. Mass spectra of triterpenyl alkanoates, novel natural products. J Mass Spectrom 32: 1356-1361.

Elias VO, Simoneit BRT, Pereira AS and Cardoso JN. 1998. High temperature gas chromatography with a glass capillary column from the analysis of high molecular weight tracers in smoke samples from biomass burning. J High Resol Chromatogr 21: 87-93.

Elias VO, Simoneit BRT, Pereira AS, Cabral JA AND CARdoso JN. 1999. Detection of high molecular weight organic tracers in vegetation smoke samples by high-temperature gas chromatography-mass spectrometry. Environ Sci Technol 33: 2369-2376.

Engling G, Herckes P, Kreidenweis SM, Malm WC AND Collett JL. 2006. Composition of the fine organic aerosol in Yosemite National Park during the 2002 Yosemite Aerosol Characterization Study. Atmos Environ 40: 2959-2972.

FABbri D, Prati S AND VASSURA I. 2002. Molecular characterisation of organic material in air fine particles $\left(\mathrm{PM}_{10}\right)$ using conventional and reactive pyrolysis-gas chromatography-mass spectrometry. J Environ Monit 4: 210-215.

FACCHINI M ET AL. 1999. Partitioning of the organic aerosol component between fog droplets and interstitial air. J Geophys Res 104: 26821-26832.

FALKOVICH AH AND RUdich Y. 2001. Analysis of semivolatile organic compounds in atmospheric aerosols by direct sample introduction. Environ Sci Technol 35: 2326-2333.

FANG GC, Wu YS, Chen MH, Ho TT, HuAng SH AND RAU JY. 2004. Polycyclic aromatic hydrocarbons study in Taichung, Taiwan, during 2002-2003. Atmos Environ 38: 3385-3391.

FAng GC, Wu YS, Chen JC, Fu PPC, Chang CN, Ho TT AND CHEN MH. 2005. Characteristic study of polycyclic aromatic hydrocarbons for fine and coarse particulates at Pastureland near industrial park sampling site of central Taiwan. Chemosphere 60: 427-433.

FANG M, ZHENG M, WANG F, TO KL, JAAFAR AB AND TONG SL. 1999. The solvent-extractable organic compounds in the Indonesia biomass burning aerosols - characterization studies. Atmos Environ 33: 783-795.

FARQuhar GD. 1997. Carbon dioxide and vegetation. Science 278: 1411-1416.

Feilberg A, Poulsen MWB, Nielsen T and Skov H. 2001. Occurrence and sources of particulate nitro-polycyclic aromatic hydrocarbons in ambient air of Denmark. Atmos Environ 35: 353-366.

Feng J, Chan CK, Fang M, Hu M, He L and Tang X. 2006. Characteristics of organic matter in $\mathrm{PM}_{2.5}$ in Shanghai. Chemosphere 64: 1393-1400.

Feng J, Guo Z, Chan CK and Fang M. 2007. Properties of organic matter in $\mathrm{PM}_{2.5}$ at Changdao Island, China A rural site in the transport path of the Asian continental outflow. Atmos Environ 41: 1924-1935.

Fine P, CASS G AND Simoneit BRT. 2001. Chemical characterization of fine particle emissions from fireplace combustion of woods grown in the Northeastern United States. Environ Sci Technol 35: 2665-2675.

Fine P, CASS G AND Simoneit BRT. 2004a. Chemical characterization of fine particle emissions from the wood stove combustion of prevalent United States tree species. Environ Eng Sci 21: 705-721.

Fine P, CASS G AND Simoneit BRT. 2004c. Chemical characterisation of fine particle emissions from fireplace combustion of wood types grown in the Midwestern and western United States. Environ Eng Sci 21: 387-409. 
Fine PM, CASS GR AND SimONEIT BRT. 2002a. Organic compounds in biomass smoke from residential wood combustion: Emissions characterization at a continental scale. J Geophys Res 107: 8349, doi:10.1029/2001JD000661.

FINE PM, CASS GR AND SimONEIT BRT. 2002b. Chemical characterisation of fine particle emissions from the fireplace combustion of woods grown in the southern United States. Environ Sci Technol 36: 1442-1451.

Fine PM, Shen S AND Sioutas C. 2004b. Inferring the sources of fine and ultrafine particulate matter at downwind receptor sites in the Los Angeles Basin using multiple continuous measurements. Aerosol Sci Technol 38 (Suppl 1): 182-195.

Fine PM, Chakrabarti B, Krudysz M, Schauer JJ AND SIOUTAS C. 2004d. Diurnal variations of individual organic compound constituents of ultrafine and accumulation mode particulate matter in the Los Angeles Basin. Environ Sci Technol 38: 1296-1304.

Fraser MP AND LAKSHMANAN K. 2000. Using levoglucosan as a molecular marker for the long-range transport of biomass combustion aerosols. Environ Sci Technol 34: $4560-4564$.

Fraser MP, CASS GR, Simoneit BRT AND Rasmussen RA. 1997. Air quality model evaluation data for organics. 4. $\mathrm{C}_{2}-\mathrm{C}_{36}$ non-aromatic hydrocarbons. Environ Sci Technol 31: 2356-2367.

Fraser MP, Cass GR and Simoneit BRT. 1999. Particulate organic compounds emitted from motor vehicle exhaust and in the urban atmosphere. Atmos Environ 33: $2715-2754$.

Fraser MP, Yue ZW, Tropp RJ, Kohl SD and Chow JC. 2002. Molecular composition of organic fine particulate matter in Houston, TX. Atmos Environ 36: 57515758.

Fraser MP, CASS GR AND Simoneit BRT. 2003. Air quality model evaluation data for organics. $6 . \mathrm{C}_{3}-\mathrm{C}_{24}$ organic acids. Environ Sci Technol 37: 446-453.

FREEMAN DJ AND CATTELl CR. 1990. Wood burning as a source of atmospheric polycyclic aromatic hydrocarbons. Environ Sci Technol 24: 1581-1585.

Friedrich C AND Kleiböhmer W. 1997. Supercritical $\mathrm{CO}_{2}$-assisted liquid extraction of polycyclic aromatic hydrocarbons and polychlorinated dibenzo- $p$-dioxins and -furans from solid matrices. J Chromatogr A 777: 289 294.

Fuzzi S, Decesari S, Facchini MC, Matta E, Mircea M And Tagliavini E. 2001. A simplified model of the water soluble organic component of atmospheric aerosol. Geophys Res Lett 20: 4079-4082.

Gagosian RB, Peltzer ET and Zafiriou OC. 1981. Atmospheric transport of continentally derived lipids to the tropical North Pacific. Nature 291: 312-314.

Gagosian RB, Zafirio O, Peltzer et and Alfor J. 1982. Lipids in aerosols from the Tropical North Pacific: temporal variability. J Geophys Res 87(C13): 1113311144.

Gagosian RB, Peltzer et and Merrill JT. 1987. Long-range transport of terrestrially derived lipids in aerosols from the South Pacific. Nature 325: 800-803.

GARREC JP. 1994. Cuticular characteristics in the detection of plant stress due to air pollution - New problems in the use of these cuticular characteristics. In: PERCY KE, CAPE JN, Jagels R And Simpson CJ (Eds), Air Pollutants and the Leaf Cuticle, Germany: NATO ASI Series, G36: $113-122$.

Glassius M, Lahaniati M, Calogirou A, Di Bella D, JENSEN NR, HJorth J, Kotzias D AND LARSEN BR. 2000. Carboxylic acids in secondary aerosols from oxidation of cyclic monoterpenes by ozone. Environ Sci Technol 34: 1001-1010.

Godoi AFL, RaVindra K, Godoi RHM, ANdrade SJ, SANTIAGO-Silva M, VAeCK LV AND GRIEKEN RV. 2004. Fast chromatographic determination of polycyclic aromatic hydrocarbons in aerosol samples from sugar cane burning. J Chromatogr A 1027: 49-53.

Gogou A, Stratigakis N, Kanakidou M and StephaNOU E. 1996. Organic aerosols in Eastern Mediterranean: components source reconciliation by using molecular markers and atmospheric back trajectories. Org Geochem 25: 79-96.

Gogou A, Apostolaki M and Stephanou E. 1998. Determination of organic markers in marine aerosols and sediments: one-step flash chromatography compound class fractionation and capillary gas chromatographic analysis. J Chromatogr A 799: 215-231.

Gordon GJ, BenNer B AND Wise S. 1989. Mobile sources of atmospheric polynuclear aromatic hydrocarbons: a road-way tunnel study. Environ Sci Technol 23: 1269-1278.

Graham B, Mayol-Bracero ol, Guyin P, Roberts GC, Decesari S, Facchini MC, Artaxo P, Maenhaut W, Köll P AND Andreae MO. 2002. Watersoluble organic compounds in biomass burning aerosols over Amazonia. 1. Characterization by NMR and GCMS. J Geophys Res 107 (D20): 8047-8062. 
Graham B, Guyon P, Taylor PE, Artaxo P, MaenHaUt W, Glovsky MM, Flagan RC AND ANDREAE MO. 2003. Organic compounds present in the natural Amazonian aerosol: Characterization by gas chromatography-mass spectrometry. J Geophys Res 108 (D24): 4766.

Graham B, Falkovich AH, Rudich Y, MaEnhaut W, GUYON P AND ANDREAE MO. 2004. Local and regional contributions to the atmospheric aerosol over Tel Aviv, Israel: a case study using elemental, ionic and organic tracers. Atmos Environ 38: 1593-1604.

Grimalt J, Albaigés J, Sicre MA, Marty JC AND SALIOT A. 1988. Aerosol transport of polynuclear aromatic hydrocarbons over the Mediterranean Sea. Naturwissenschaften 75: 39-42.

Grimmer G, Jacob J, Naujack KW and Dettbarn G. 1983. Determination of polycyclic aromatic compounds emitted from brown-coal-fired residential stoves by gas chromatography/gas spectrometry. Anal Chem 55: 892900 .

Grosjean D and Seinfeld JH. 1989. Parameterization of the formation potential of secondary organic aerosols. Atmos Environ 23: 1733-1747.

Grosjean D, Williams EL and Seinfeld JH. 1992. Atmospheric oxidation of selected terpenes and related carbonyls: gas-phase carbonyl products. Environ Sci Technol 26: $1526-1533$.

GÜNTHARDT-Goerg MS. 1994. The effect of the environment on the structure, quantity and composition of spruce needle wax. In: PERCY KE, CAPE JN, JAgels R AND Simpson CJ (Eds), Air Pollutants and the Leaf Cuticle, Germany: NATO ASI Series, G36: 165-174.

Guo ZG, Sheng LF, Feng JL And Fang M. 2003. Seasonal variation of solvent extractable organic compounds in the aerosols in Qingdao, China. Atmos Environ 37: $1825-1834$.

Guo ZG, Feng JL, Fang M, Chen HY and Lau KH. 2004. The elemental and organic characteristics of $\mathrm{PM}_{2.5}$ in Asian dust episodes in Qingdao, China, 2002. Atmos Environ 38: 909-919.

Guyon P, Graham B, Robert G, Mayol-Bracero OL, Maenhaut W, Artaxo P and Andreae MA. 2004. Sources of optically active aerosol particles over the Amazon forest. Atmos Environ 38: 1039-1051.

Hakola H, Arey J, Aschmann S And Atkinson R. 1994. Product formation from the gas-phase reactions of $\mathrm{OH}$ radicals and $\mathrm{O}_{3}$ with a series of monoterpenes. J Atmos Chem 18: 75-102.
Halsall CJ, Barrie LA, Fellin P, Muir GC, Billeck BN, LOCKHART L, RovindsKy FY, KonONOV EY AND PASTUKLOV B. 1997. Spatial and temporal variation of polycyclic aromatic hydrocarbons in the Arctic atmosphere. Environ Sci Technol 31: 3593-3599.

HARRAD S, HASSOUN S, ROMERO MSC AND HARRISON RM. 2003. Characterisation and source attribution of the semi-volatile organic content of atmospheric particles and associated vapour phase in Birmingham, UK. Atmos Environ 37: 4985-4991.

HARrison RM, TILling R, ROMERo MSC, HARRAD S AND JARVIS K. 2003. A study of trace metals and polycyclic aromatic hydrocarbons in the roadside environment. Atmos Environ 37: 2391-2402.

HaVers N, Burba P, LAmbert J AND Klockow D. 1998. Spectrometric characterization of humic-like substances in airborne particulate matter. J Atmos Chem 29: 45-54.

Hawthorne SB ANd Miller DJ. 1987. Extraction and recovery of polycyclic aromatic hydrocarbons from environmental matrices using supercritical fluid extraction. Anal Chem 59: 1705-1708.

Hawthorne SB, Miller DJ, Barkley RM and KrieGER MS. 1988. Identification of methoxylated phenols as candidate tracers for atmospheric wood smoke pollution. Environ Sci Technol 23: 1191-1196.

Hayakawa K, Tang N, Akutsu K, Murahashi T, Kakimoto H, KizU R and Toriba A. 2002. Comparison of polycyclic aromatic hydrocarbons and nitropolycyclic aromatic hydrocarbons in airborne particulates collected in downtown and suburban Kanazawa, Japan. Atmos Environ 36: 5535-5541.

Hays MD, Geron CD, Linna KJ, SMith ND AND SCHAUER JJ. 2002. Speciation of gas-phase and fine particle emissions from burning of foliar fuels. Environ Sci Technol 36: 2281-2295.

Hays MD, Finem PM, Geron CD, KleEman MJ AND GuLlETt BK. 2005. Open burning of agricultural biomass: Physical and chemical properties of particle-phase emissions. Atmos Environ 39: 6747-6764.

Herckes P, Engling G, Kreidenweis SM and ColLETT JL. 2006. Particle size distributions of organic aerosol constituents during the 2002 Yosemite Aerosol Characterization Study. Environ Sci Technol 40: 4554-4562.

Hildemann LM, Mazurek MA and Cass GR. 1991. Quantitative characterization of urban sources of organic aerosols by high-resolution gas-chromatography. Environ Sci Technol 25: 1311-1325. 
Hildemann LM, KLinedinst DB, Klouda GA, Currie LA AND CASS GR. 1994. Sources of urban contemporary carbon aerosol. Environ Sci Technol 28: 1565-1576.

Hildemann LM, Rogge WF, Cass GR, Mazurek MA AND SIMONEIT BRT. 1996. Contribution of primary aerosol emissions from vegetation-derived sources to fine particle concentrations in Los Angeles. J Geophys Res 101: 19541-19549.

Hill HH, Chan KW and KaraseK FW. 1977. Extraction of organic compounds from airborne particulate matter for gas chromatographic analysis. J Chromatogr 131: $245-252$.

Ho KF, LEE SC AND CHIU GMY. 2002. Characterization of selected volatile organic compounds, polycyclic aromatic hydrocarbons and carbonyl compounds at a roadside monitoring station. Atmos Environ 36: 57-65.

HobBs PV. 2002. Clean air slots amid atmospheric pollution. Nature 415: 861.

Hoppel W ET AL. 2001. Particle formation and growth from ozonolysis of $\alpha$-pinene. J Geophys Res 106: $27603-$ 27618.

Hou X, Zhuang G, SUn Y And Na Z. 2006. Characteristics and sources of polycyclic aromatic hydrocarbons and fatty acids in $\mathrm{PM}_{2.5}$ aerosols in dust season in China. Atmos Environ 40: 3251-3262.

HUNG H ET AL. 2005. Temporal and spatial variabilities of atmospheric polychlorinated biphenyles (PCBs), organochlorine (OC) pesticides and polycyclic aromatic hydrocarbons (PAHs) in the Canadian Arctic: results from a decade of monitoring. Sci Total Environ 342: 119-144.

Ion AC, Vermeylen R, Kourtchev I, CAFmeyer J, Chi X, Gelencser A, Maenhaut W and Claeys M. 2005. Polar organic compounds in rural $\mathrm{PM}_{2.5}$ aerosols from K-puszta, Hungary, during a 2003 summer field campaign: sources and diurnal variations. Atmos Chem Phys Disc 5: 1863-1889.

JACOBSON MC, Hansson HC, NoON KJ AND ChaRlson RJ. 2000. Organic atmospheric aerosols: Review and state of the science. Rev Geophys 38: 267-294.

JANG M AND MCDOW SR. 1997. Products of benz[ $a$ ]anthracene photodegradation in the presence of known organic constituents of atmospheric aerosols. Environ Sci Technol 31: 1046-1053.

Jang M, Czoschke M, Lee S and Kamens RM. 2002. Heterogeneous atmospheric aerosol production by acidcatalyzed particle phase reactions. Science 298: 814-817.

JAOUI M AND KAMENS RM. 2003. Mass gaseous and par- ticulate oxidation products of the reaction from a mixture of $\alpha$-pinene $+\beta$-pinene $/ \mathrm{O}_{3} /$ air in the absence of light and $\alpha$-pinene $+\beta$-pinene $/ \mathrm{NO}_{\mathrm{x}} /$ air in the presence of natural sunlight. J Atmos Chem 44: 259-297.

JAOUi M, KLEINDienst TE, LewANDOWSKi M, OfFenBERG JH AND EDNEY EO. 2005. Identification and quantification of polar oxygenated compounds bearing carboxylic or hydroxyl groups. 2. Organic tracer compounds from monoterpenes. Environ Sci Technol 39: 5661-5673.

JAYARATNE ER AND VERNA TS. 2001. The impact of biomass burning on the environmental aerosol concentration in Gaborone, Botswana. Atmos Environ 35: 1821-1828.

JiAO K AND LAFLEUR AL. 1997. Improved detection of polycyclic aromatic compounds in complex mixtures by liquid chromatography fractionation on poly(divinyl)benzene prior to gas chromatography-mass spectrometry. Application to the analysis of diesel particulates. J Chromatogr A 791: 203-211.

JOHNSTON M AND WEXLER S. 1995. MS of individual aerosol particles. Anal Chem 67: 721A-726A.

JordAn TB, SEEN AJ AND JACOBSEN GE. 2006. Levoglucosan as an atmospheric tracer for woodsmoke. Atmos Environ 40: 5316-5321.

Kalaitzoglou M, Terzi E and Samara C. 2004. Patterns and sources of particle-phase aliphatic and polycyclic hydrocarbons in urban and rural sites of western Greece. Atmos Environ 38: 2545-2560.

KALBERER M ET AL. 2004. Identification of polymers as major components of atmospheric aerosols. Science 303 : $1659-1662$.

Kalberer M, Sax M and Samburova V. 2006. Molecular size evolution of oligomers in organic aerosols collected in urban atmospheres and generated in a smog chamber. Environ Sci Technol 40: 5917-5922.

KAllio M, HyötyläInen T, LEhtonen M, JusSila M, Hartonen K, Shimmo M And RiekKola ML. 2003. Comprehensive two-dimensional gas chromatography in the analysis of urban aerosols. J Chromatogr A 1019: 251-260.

KAMENS RM AND JAOUI M. 2001. Modeling aerosol formation from $\alpha$-pinene $+\mathrm{NO}_{\mathrm{x}}$ in the presence of natural sunlight using gas phase kinetics and gas-particle partitioning theory. Environ Sci Technol 35: 1394-1405.

Karasek FW, Denney DW, Chan KW and Clement RE. 1978. Analysis of complex organic mixtures on airborne particulate matter. Anal Chem 50: 82-87. 
Kavouras IG And Stephanou EG. 2002a. Direct evidence of atmospheric secondary organic aerosol formation in forest atmosphere through heteromolecular nucleation. Environ Sci Technol 36: 5083-5091.

Kavouras IG and Stephanou EG. 2002b. Particle size distribution of organic primary and secondary aerosol constituents in urban, background marine and forest atmosphere. J Geophys Res 107 (D8), 4069, doi: 10.1029/ 2000JD000278.

Kavouras IG, Stratigakis N and Stephanou EG. 1998a. Iso- and anteiso-alkanes: specific tracers of environmental tobacco smoke in indoor and outdoor particlesize distributed urban aerosols. Environ Sci Technol 32: 1369-1377.

Kavouras IG, Mihalopoulos N and Stephanou EG. 1998b. Formation of atmospheric particles from organic acids produced by forests. Nature 395: 683-686.

Kavouras IG, Lawrence J, Koutrakis P, StephaNOU EG AND OYOLA P. 1999a. Measurement of particulate aliphatic and polynuclear aromatic hydrocarbons in Santiago do Chile: source reconciliation and evaluation of sampling artifacts. Atmos Environ 33: 4977-4986.

Kavouras IG, Mihalopoulos N and Stephanou EG. 1999b. Formation and gas/particle partitioning of monoterpene photo-oxidation products over forests. Geophys Res Lett 26: 55-59.

Kavouras IG, Mihalopoulos N and Stephanou EG. 1999c. Secondary organic aerosol formation $v s$. primary organic aerosol emission: In situ evidence for the chemical coupling between monoterpene acidic photooxidation products and new particle formation over forests. Environ Sci Technol 33: 1028-1037.

KaVouras IG, Koutrakis P, TSAPAKIS M, LAgOUdAKI E, Stephanou EG, BAer DV and Oyola P. 2001a. Source apportionment urban particulate aliphatic and polynuclear aromatic hydrocarbons using multivariable methods. Environ Sci Technol 35: 2288-2294.

Kavouras IG, Stratigakis N and Stephanou EG. 2001b. Chemical characterization of emissions from vegetable oil processing and their contribution to aerosol mass using the organic molecular markers approach. J Air Waste Manage Assoc 51: 552-561.

KAWAMURA K. 1995. Land-derived lipid class compounds in the deep-sea sediments and marine aerosols from North Pacific. In: SAKai H AND NozAKI Y (Eds), Biogeochemical Processes and Ocean Flux in the Western Pacific, Tokyo: Terrapub, p. 31-51.
KAWAMURA K AND GAGOSIAN RB. 1987. Implication of $\omega$-oxocarboxylic acids in the remote marine atmosphere for photo-oxidation of unsaturated fatty acids. Nature 325 : $330-332$.

KAWAMURA K AND KAPLAN IR. 1987. Organic compounds in the rainwater of Los Angeles. Environ Sci Technol 17: 497-501.

KaWAmura K AND Yasui O. 2005. Diurnal changes in the distribution of dicarboxylic acids, ketocarboxylic acids and dicarbonyls in the urban Tokyo atmosphere. Atmos Environ 39: 1945-1960.

Kawamura K, Kasukabe H and Barrie L. 1996. Source and reaction pathways of dicarboxylic acids, ketoacids and dicarbonyls in Arctic aerosols: one year of observations. Atmos Environ 30: 1709-1722.

KAWAMURA K, Ishimura Y And YamaZaKi K. 2003. Four years' observations of terrestrial lipid class compounds in marine aerosols from the western North Pacific. Global Biogeochem Cycles 17: 1003, doi:10.1029/ $2001 \mathrm{~GB} 001810$.

Kendall M, Hamilton RS, Watt J And Williams ID. 2001. Characterisation of selected speciated organic compounds associated with particulate matter in London. Atmos Environ 35: 2483-2495.

KeshtKar H And Ashbaugh LL. 2007. Size distribution of polycyclic aromatic hydrocarbon particulate emission factors from agricultural burning. Atmos Environ 41: 2729-2739.

Kesselmeier J And Staudt M. 1999. Biogenic volatile compounds (VOC): an overview on emission, physiology and ecologic. J Atmos Chem 33: 23-88.

Ketseridis G, Hahn J, Jaenicke R and Junge C. 1976. The organic constituents of atmospheric particulate matter. Atmos Environ 10: 603-610.

Keywood MD, Ayers GP, Gras JL, Gillett RW AND COHEN DD. 2000. Size distribution and sources of aerosol in Launceston, Australia, during winter 1997. J Air Waste Manage Assoc 50: 418-427.

Khalil MAK and RaSmussen RA. 2003. Tracers of wood smoke. Atmos Environ 37: 1211-1222.

Khalili NR, SCheFF PA AND Holsen TM. 1995. PAH source fingerprints for coke ovens, diesel and gasoline engines, highway tunnels and wood combustion emissions. Atmos Environ 29: 533-542.

Kim E, Hopke P, Larson T, Maykut N ANd Lewtas J. 2004. Factor analysis of Seattle fine particles. Aerosol Sci Technol 38: 724-738. 
Kiss G, Tombácz E, Varga B, Alsberg T and PersSON L. 2003. Estimation of the average molecular weight of humic-like substances isolated from fine atmospheric aerosol. Atmos Environ 37: 3783-3794.

KJÄllstrand J, RAmnÄS O AND Petersson G. 2000. Methoxyphenols from burning of Scandinavian forest plant Materials. Chemosphere 41: 735-741.

Kleeman MJ, Schauer JJ And Cass GR. 1999. Size and composition distribution of fine particulate matter emitted from wood burning, meat charbroiling and cigarettes. Environ Sci Technol 33: 3516-3523.

Knecht U AND Woitowitz HJ. 1988. PAH-losses from glass fibber filters under the conditions of different air volume sampling: results of field evaluations in occupational atmospheres. Fresenius J Anal Chem 331: 8-13.

Korfmacher WA, Rushing LC, Arey J, Zielinska B AND PITTS JN. 1987. Identification of mononitropyrenes and mononitroflouranthenes in air particulate matter via fused silica gas pressure ionization mass spectrometry. J High Resolut Chromatogr Chromatogr Commun 10: 641-646.

Kotzias D, Fytianos K And Geiss F. 1990. Reaction of monoterpenes with ozone, sulphur dioxide and nitrogen dioxide gas-phase oxidation of $\mathrm{SO}_{2}$ and formation of sulphuric acid. Atmos Environ 24A: 2127-2132.

Kourtchev I, RuUskanen W, Maenhaut W, KulMala M AND Claeys M. 2005. Observation of 2methyltetrols and related photo-oxidation products of isoprene in boreal forest aerosols from Hyytiala, Finland. Atmos Chem Phys 5: 2761-2770.

Kozlowski TT and Pallardy S. 1997. Physiology of woody plants, $2^{\text {nd }}$ ed., San Diego, CA, USA: Academic Press.

Krivácsy Z, Hoffer A, SÁrvÁri Z, Temesi D, BALtensperger U, Nyeki S, Weingartner E, KleeFELD S AND JENNINGS SG. 2001. Role of organic and blackcarbon in the chemical composition of atmospheric aerosol at European background sites. Atmos Environ 35: 6231-6244.

Kubátová A, Vermeylen R, Claeys M, Cafmeyer J, Maenhaut W, Roberts G and Artaxo P. 2000. Carbonaceous aerosol characterization in the Amazon basin, Brazil: novel dicarboxylic acids and related compounds. Atmos Environ 34: 5037-5051.

KubÁtová A, Vermeylen R, Claeys M, Cafmeyer J AND MAENhAUT W. 2002. Organic compounds in urban aerosol from Gent, Belgium: Characterization, sources and seasonal differences. J Geophys Res 107(D21), 8343,
doi:10.1029/2001JD000556.

LaKind JS, Jenkins RA, Naiman DQ, Ginevan ME, GRAVES CG AND TARDIFF RG. 1999. Use of environmental tobacco smoke constituents as markers for exposure. Risk Anal 19: 359-373.

LANG Q, ZhANG Q AND JAFFÉ R. 2002. Organic aerosols in the Miami area, USA: temporal variability of atmospheric particles and wet/dry deposition. Chemosphere 47: 427-441.

Larsen BR, Di Bella D, Glasius M, Winterhalter R, JENSEN NR AND HJorth J. 2001. Gas-phase OH oxidation of monoterpenes: gaseous and particulate products. J Atmos Chem 38: 231-276.

LARSEn RK, Schantz MM And Wise SA. 2006. Determination of levoglucosan in particulate matter reference materials. Aerosol Sci Technol 40: 781-787.

LAU APS, LeE AKY, Chan CK AND FAng M. 2006. Ergosterol as a biomarker for the quantification of the fungal biomass in atmospheric aerosols. Atmos Environ 40: 249-259.

LAURENT JP AND AlLen DT. 2004. Size distributions of organic functional groups in ambient aerosol collected in Houston, Texas. Aerosol Sci Technol 38 (Suppl 1): 82-91.

LEADERER BP AND HAMMOND SK. 1991. Evaluation of vapor-phase nicotine and respirable suspended particle mass as markers for environmental tobacco-smoke. Environ Sci Technol 25: 770-777.

Lee S, Baumann K, Schauer JJ, Sheesley RJ, Naeher LP, Meinardi SE, Blake DR, Edgerton S, Russel AG And Clements M. 2005. Gaseous and particulate emissions from prescribed burning in Georgia. Environ Sci Technol 39: 9049-9056.

LeE SC, Ho KF, Chan LY, Zielinska B AND ChOW JC. 2001. Polycyclic aromatic hydrocarbons (PAHs) and carbonyl compounds in urban atmosphere of Hong Kong. Atmos Environ 35: 5949-5960.

LeE WJ, Liow MC, Tsai PJ AND Hsieh LT. 2002. Emission of polycyclic aromatic hydrocarbons from medical waste incinerators. Atmos Environ 36: 781-790.

LEWANDOWSKi M, JaOUi M, KLEINDIENST TE, OfFENBERG JH AND EDNEY EO. 2007. Composition of $\mathrm{PM}_{2.5}$ during the summer of 2003 in Research Triangle Park, North Caroline. Atmos Environ 41: 4073-4083.

Lewis AC, Kupiszewska D, BARTLE KD AND Pilling MJ. 1995. City centre concentrations of polycyclic aromatic hydrocarbons using supercritical fluid extraction. Atmos Environ 29: 1531-1542. 
LI CK AND KAMENS RM. 1993. The use of polycyclic aromatic hydrocarbons as source signatures in receptor modelling. Atmos Environ 27: 523-532.

Li CT, Lin YC, LEe WJ AND TSAi PJ. 2003. Emission of polycyclic aromatic hydrocarbons and their carcinogenic potencies from cooking sources to the urban atmosphere. Environ Health Persp 111: 483-487.

Li M, McDow SR, Tollerud DJ And Mazurek MA. 2006. Seasonal abundance of organic molecular markers in urban particulate matter from Philadelphia, PA. Atmos Environ 40: 2260-2273.

LigOCKI MP AND PANKOW JF. 1989. Measurements of the gas/particle distributions of atmospheric organic compounds. Environ Sci Technol 23: 75-83.

LIM LH, HARRISON RM AND HARRAD S. 1999. The contribution of traffic to atmospheric concentrations of polycyclic aromatic hydrocarbons. Environ Sci Technol 33: 3538-3542.

Lim MCH, Ayoko GA, Morawska L, Ristovski ZD AND JAYARATNE ER. 2005. Effect of fuel composition and engine operating conditions on polycyclic aromatic hydrocarbon emissions from a fleet of heavy-duty diesel buses. Atmos Environ 39: 7836-7848.

Lim MCH, Ayoko GA, Morawska L, Ristovski ZD AND JAYARATNE ER. 2007. Influence of fuel composition on polycyclic aromatic hydrocarbon emissions from a fleet of in-service passenger cars. Atmos Environ 41: $150-160$.

LiU Y, Sklorz M, Schnelle-Kreis J, Orasche J, Ferge T, Kettrup A and Zimmermann R. 2006. Oxidant denuder sampling for analysis of polycyclic aromatic hydrocarbons and their oxygenated derivates in ambient aerosol: Evaluation of sampling artefact. Chemosphere 62: 1889-1898.

Lough GC, Schauer JJ And Lawson DR. 2006. Dayof-week trends in carbonaceous aerosol composition in the urban atmosphere. Atmos Environ 40: 4137-4145.

Lyall RJ, HoOper MA AND MaInwaring SJ. 1988. Polycyclic aromatic hydrocarbons in the Latrobe Valley. Atmos Environ 22: 2549-2555.

MAHLMAN JD. 1997. Uncertainties in projections of humancaused climate warming. Science 278: 1416-1417.

Manchester-Neesvig JB, Schauer JJ And Cass GR. 2003. The distribution of particle-phase organic compounds in the atmosphere and their use for source apportionment during the southern California children's health study. J Air Waste Manage Assoc 53: 1065-1079.
Mandalakis M, Tsapakis M, Tsoga A And StephaNOU EG. 2002. Gas-particle concentrations and distribution of aliphatic hydrocarbons, PAHs, PCBs and PCDD/Fs in the atmosphere of Athens (Greece) Atmos Environ 36: 4023-4035.

Manoli E, Kouras A And Samara C. 2004. Profile analysis of ambient and source emitted particle-bound polycyclic aromatic hydrocarbons from three sites in northern Greece. Chemosphere 56: 867-878.

Mao IF, Chen CN, Lin YC And Chen ML. 2007. Airborne particle $\mathrm{PM}_{2.5} / \mathrm{PM}_{10}$ mass distribution and particlebound PAH concentrations near a medical waste incinerator. Atmos Environ 41: 2467-2475.

Marino F, Cecinato A And Siskos PA. 2000. Nitro-PAH in ambient matter in the atmosphere of Athens. Chemosphere 40: 533-537.

Martinis MS, OKamoto RA, KADo NY, Gundel LA, Lilian RF AND CARVALHO LRF. 2002. Polycyclic aromatic hydrocarbons in a bioassay-fractionated extract of $\mathrm{PM}_{10}$ collected in São Paulo, Brazil. Atmos Environ 36: 307-314.

Masclet P, Cachier H, Liousse C and Wortham H. 1995. Emissions of polycyclic aromatic hydrocarbons by savanna fires. J Atmos Chem 22: 41-54.

Matsunaga S, Mochida M and Kawamura K. 2003. Growth of aerosols by semi-volatile carbonyls in the forestal atmosphere. Atmos Environ 37: 2045-2050.

Matsunaga S, Mochida M And Kawamura K. 2004. Variation on the atmospheric concentrations of biogenic carbonyl compounds and their removal processes in the northern forest at 20 Moshiri, Hokkaido Island, Japan. J Geophys Res 109: 4302, doi:10.1029/2003JD004100.

Mayol-Bracero ol, Rosario O, Corrigan CE, Morales R, Torres I AND PÉrez V. 2001. Chemical characterization of submicron organic aerosols in the tropical trade winds of the Caribbean using gas chromatography/mass spectrometry. Atmos Environ 35: 1735-1745.

MAZUREK MA. 2002. Molecular identification of organic compounds in atmospheric complex mixtures and relationships to atmospheric chemistry and sources. Environ Health Perspect 110 (Suppl 6): 995-1003.

McDonald JD, Barr EB, White RK, Chow JC, Schauer JJ, Zielinska B and Grosjean E. 2004. Generation and characterization of four dilutions of diesel engine exhaust for a subchronic inhalation study. Environ Sci Technol 38: 2513-2522.

Medeiros PM, Conte MH, Weber JC and Simoneit 
BRT. 2006. Sugars as source indicators of biogenic organic carbon in aerosols collected above the Howland Experimental Forest, Maine. Atmos Environ 40: 1694-1705.

Miguel AH ANd Pereira PA. 1989. Benzo(k)fluoranthene, benzo(ghi)perylene and indeno(1,2,3-cd)pyrene: new tracers of automobile emissions in receptor modelling. Aerosol Sci Technol 10: 292-295.

Minoia C, Magnaghi S, Micoli G, Fiorentino ML, Turci R, ANgeleri S ANd BerRi A. 1997. Determination of environmental reference concentration of six PAHs in urban areas (Pavia, Italy). Sci Total Environ 198: 33-41.

MorRicAl BD AND ZENOBI R. 2002. Determination of tracer compounds for environmental tobacco smoke aerosol by two step laser mass spectrometry. Atmos Environ 36: $801-811$.

Neusüss C, Pelzing M, Plewka A and Herrmann H. 2000. A new analytical approach for size-resolved speciation of organic compounds in atmospheric aerosol particles: Methods and first results. J Geophys Res 105: 4513-4527.

Nielson T, Jørgensen He, Larsen JC And Poulsen M. 1996. City air pollution of polycyclic aromatic hydrocarbons and other mutagens: occurance, sources and health effects. Sci Total Environ 189/190: 41-49.

Nolte CG, Schauer JJ, CAss GN AND Simoneit BRT. 1999. Highly polar organic compounds present in meat smoke. Environ Sci Technol 33: 3313-3316.

Nolte CG, Schauer JJ, CAss GR and Simoneit BRT. 2001. Highly polar organic compounds present in wood smoke and in the ambient atmosphere. Environ Sci Technol 35: 1912-1919.

Nolte CG, Schauer JJ, Cass GR and Simoneit BRT. 2002. Trimethylsilyl derivatives of organic compounds in source samples and in atmospheric fine particulate matter. Environ Sci Technol 36: 4273-4281.

OChSEnKühn-Petropoulou M, Staikos K, MatusCHEK G AND Kettrup A. 2003. On-line determination of polycyclic aromatic hydrocarbons in airborne particulate matter by using pyrolysis/GC-MS. J Anal Appl Pyrolysis 70: 73-85.

Oda J, Nomura S, Yasuhara A and Shibamoto T. 2001. Mobile sources of atmospheric polycyclic hydrocarbons in a roadway tunnel. Atmos Environ 35: 4819 4827

Ohura T, Amagai T, Fusaya M and Matsushita H. 2004. Polycyclic aromatic hydrocarbons in indoor and outdoor environments and factors affecting their concentrations. Environ Sci Technol 38: 77-83.

OKUdA T, NARAOKA H AND Ishiwatari R. 2000. Separation of PAHs in environmental samples by use of solidphase extraction system for carbon isotope analysis. J Mass Spectrom Soc Jpn 48: 387-394.

OKUdA T, KUMATA K, ZaKaria P, NARAOKA H, IShIWATARI R AND TAKADA H. 2002. Source identification of Malaysian atmospheric polycyclic aromatic hydrocarbons nearby forest fires using molecular and isotopic compositions. Atmos Environ 36: 611-618.

Okuda $\mathrm{T}$, Naoi D, Tenmoku M, Tanaka $\mathrm{S}$, He $\mathrm{K}$, Ma Y, Yang F, Lei Y, Jia Y and Zhang D. 2006. Polycyclic aromatic hydrocarbons (PAHs) in the aerosol in Beijing, China, measured by aminopropylsilane chemically-bonded stationary-phase column chromatography and HPLC/fluorescence detection. Chemosphere 65: $427-465$.

Oliveira CJS ET AL. 2007a. Seasonal distribution of polar organic compounds in the urban atmosphere of two large cities from the North and South of Europe. Atmos Environ 41: 5555-5570.

Oliveira T, Pio C, Alves C, Silvestre AJD, Evtyugina M, Afonso J, Caseiro A And Legrand M. 2007b. Air quality and organic compounds in aerosols from a coastal rural area in the western Iberian Peninsula over a year long period: Characterisation, loads and seasonal trends. Atmos Environ 41: 3631-3643.

Oliveira T, Pio C, Alves C, Silvestre AJd, Evtyugina M, Afonso J, Fialho P, Legrand M, PuXBAUM H AND GELENCSÉR A. 2007c. Seasonal variation of particulate lipophilic organic compounds at non-urban sites in Europe. J Geophys Res 112, D23S09, doi:10.1029/ 2007JD008504.

Omar NYMJ, Abas MrB, Ketuly KA and Tahir NM. 2002. Concentrations of PAHs in atmospheric particles $\left(\mathrm{PM}_{10}\right)$ and roadside soil particles collected in Kuala Lumpur, Malaysia. Atmos Environ 36: 247-254.

OROS DR AND SIMONEIT BRT. 1999. Identification of molecular tracers in organic aerosols from temperate climate vegetation subjected to biomass burning, Aerosol Sci Technol 31: 433-445.

Oros DR AND SIMONEIT BRT. 2000. Identification and emission rates of molecular tracers in coal smoke particulate matter. Fuel 79: 515-536.

OROS DR AND SIMONEIT BRT. 2001a. Identification and emission factors of molecular tracers in organic aerosols 
from biomass burning. Part 1. Temperate climate conifers. Appl Geochem 16: 1513-1544.

Oros DR AND SimoneIT BRT. 2001b. Identification and emission factors of molecular tracers in organic aerosols from biomass burning. Part 2. Decidous trees. Appl Geochem 16: 1545-1565.

Oros DR, Standley LJ, Chen X And Simoneit BRT. 1999. Epicuticular wax compositions of predominant conifers of Western North America. Z Naturforsch 54c: $17-24$.

Palen EJ, Allen DT, Pandis Sn, Paulson Se, SeinFELD JH AND FLAGAN RC. 1992. Fourier transform infrared analysis of aerosol formed in the photo-oxidation of isoprene and $\beta$-pinene. Atmos Environ 26A: 1239-1251.

PARK SS, KIM YJ AND FUnG K. 2002. PM 2.5 carbon measurements in two urban areas: Seoul and Kwangju, Korea. Atmos Environ 36: 1287-1297.

Pashynska V, Vermeylen R, Vas G, Maenhaut W AND Claeys M. 2002. Development of a gas chromatographic/ion trap mass spectrometric method for the determination of levoglucosan and saccharidic compounds in atmospheric aerosols. Application to urban aerosols. J Mass Spectrom 37: 1249-1257.

Paulson SE, Pandis SN, Baltensperger U, Seinfeld JH, Flagan RC, Palen EJ, Allen DT, Schaffner C, Giger W And Portmann A. 1990. Characterisation of photochemical aerosols from biogenic hydrocarbons. J Aerosol Sci 21: S245-S248.

Pedersen PS, IngWersen J, Nielsen T AND LARsen E. 1980. Effects of fuel, lubricant and engine operating parameters on the emission of polycyclic aromatic hydrocarbons. Environ Sci Technol 14: 71-79.

Penner Je, Chuang CC And Grant K. 1998. Climate forcing by carbonaceous and sulphate aerosols. Clim Dynam 14: 839-851.

Percy Ke, MCQuattie CJ And Rebbeck JA. 1994. Effects of air pollutants on epicuticular wax chemical composition. In: PERCY KE, CAPE JN, JAGELS R AND SIMPSON CJ (Eds), Air Pollutants and the Leaf Cuticle, Germany: NATO ASI Series, G36: 67-79.

Pereira We, Rostad Ce, Taylor he and Klein JM. 1982. Characterization of organic contaminants in environmental samples associated with Mount St. Helens 1980 volcanic eruption. Environ Sci Technol 16: 387-396.

Perrini G, Tomasello M, Librando V and Minniti Z. 2005. Nitrated PAHs in the environment: formation, occurrence and analysis. Ann Chim 95: 567-577.
Pio C, Alves C And Duarte A. 2001a. Organic composition of aerosols in a forested area of central Greece. Atmos Environ 35: 389-401.

Pio C, Alves C and Duarte A. 2001b. Identification, abundance and origin of atmospheric particulate matter in a Portuguese rural area. Atmos Environ 35: 1365-1375.

Pio C, Alves C, Oliveira T, Afonso J, Caseiro A, Puxbaum H, Kasper-Giebl A, Preunkfert S, Legrand M ANd Gelencsér A. 2007. Composition and source apportionment of atmospheric aerosols in Portugal during the 2003 summer intense forest fire period. In: Borrego C And Brebila C (Eds), Air Pollution 2007 Proceedings, Wessex Institute of Technology, UK: WIT Transactions on Ecology and the Environment, p. $45-58$.

Plewka A, Hofmann D, Müller K and Herrmann H. 2003. Determination of biogenic organic compounds in airborne particles by solvent extraction, derivatisation and mass spectrometric detection. Chromatographia 57: S253-S259.

Plewka A, Gnauk T, Brüggemann E and Herrmann H. 2006. Biogenic contributions to the chemical composition of airborne particles in a conifeours forest in Germany. Atmos Environ 40: S103-S115.

Pope CA, Burnett Tr, Thurston GD, Thun MJ, Calle Ee, Krewski D and Godleski JJ. 2004. Cardiovascular mortality and long-term exposure to particulate air pollution - Epidemiological evidence of general pathophysiological pathways of disease. Circulation 109: 71-77.

Poschl U. 2005. Atmospheric aerosols: Composition, transformation, climate and health effects. Angew Chem Int Ed 44: 7520-7540.

Prahl FG AND CARPenter R. 1983. Polycyclic aromatic hydrocarbons (PAH)-phase associations in Washington Coastal sediment. Geochim Cosmochim Acta 47: 10131023.

Prevedouros K, Jones KC and Sweetman AJ. 2004. Modelling the atmospheric fate and seasonality of polycyclic aromatic hydrocarbons in the UK. Chemosphere 56: $195-208$.

PRUEL RG AND QUIN JG. 1988. Accumulation of polycyclic aromatic hydrocarbons in crank-case oil. Environ Pollut 49: 89-97.

Puxbaum H, Sánchez-Ochoa A, Kasper-Giebl A, Caseiro A, Claeys M, Gelencsér A, Legrand M, Preunkert S AND Pio C. 2007. Levoglucosan 
levels at background sites in Europe for assessing the impact of biomass combustion on the European aerosol background. J Geophys Res 112: D23S05, doi:10.1029/ 2006JD008114.

QUerol X ET AL. 2004. Speciation and origin of $\mathrm{PM}_{10}$ and $\mathrm{PM}_{2.5}$ in selected European cities. Atmos Environ 38: 6547-6555

Reilly PTA, Gieray RA, Whitten WB AND RAMSEy JM. 1998. Real-time characterization of the organic composition and size of individual diesel engine smoke particles. Environ Sci Technol 32: 2672-2679.

Ré-Poppi N And Santiago-Silva S. 2002. Polycyclic aromatic hydrocarbons and other selected organic compounds in ambient air of Campo Grande City, Brazil. Atmos Environ 39: 2839-2850.

Rinehart LR, Fujita EM, Chow JC, Magliano K AND ZIELINSKA B. 2006. Spatial distribution of $\mathrm{PM}_{2.5}$ associated organic compounds in central California. Atmos Environ 40: 290-303.

Rissanen T, HyÖTYLÄINEN T, KALLIo M, KRONHOLM J, Kulmala M and Riekkola ML. 2006. Characterization of organic compounds in aerosol particles from a coniferous forest by GC-MS. Chemosphere 64: 11851195.

Robinson AL, Subramanian R, Donahue NM, BerNARDO-BRICKER A AND Rogge WF. 2006a. Source apportionment of molecular markers and organic aerosol. 2. Biomass smoke. Environ Sci Technol 40: 7811-7819.

Robinson AL, Subramanian R, Donahue NM, BerNARDO-Bricker A AND Rogge WF. 2006b. Source apportionment of molecular markers and organic aerosol. 3. Food cooking emissions. Environ Sci Technol 40: $7820-7827$

Rogge W, Hildemann L, Mazurek MA, Cass GR and SimONEIT BRT. 1998. Sources of fine organic aerosol. 9. Pine, oak and synthetic log combustion in residential fireplaces. Environ Sci Technol 32: 13-22.

Rogge WF, Hildemann LM, Mazurek MA, CAss GR AND SIMONEIT BRT. 1991. Sources of fine organic aerosol. 1. Charbroilers and meat cooking operations. Environ Sci Technol 25: 1112-1125.

Rogge WF, Hildemann LM, Mazurek MA, Cass GR AND SIMONEIT BRT. 1993a. Sources of fine organic aerosol. 3. Road dust, tire debris and organometallic brake lining dust: roads as sources and sinks. Environ Sci Technol 27: 1892-1904.

Rogge WF, Hildemann LM, Mazurek MA, Cass GR
AND SIMONEIT BRT. 1993b. Sources of fine organic aerosol. 4. Particulate abrasion products from leaf surfaces of urban plants. Environ Sci Technol 27: 27002711.

Rogge WF, Hildemann LM, Mazurek MA, Cass GR AND SIMONEIT BRT. 1993c. Sources of fine organic aerosol. 5. Natural gas home appliances. Environ Sci Technol 27: 2736-2744.

Rogge WF, Hildemann LM, Mazurek MA, Cass GR AND Simoneit BRT. 1993d. Sources of fine organic aerosol. 2. Noncatalyst and catalyst-equipped automobiles and heavy-duty diesel trucks. Environ Sci Technol 27: 636-651.

Rogge WF, Mazurek MA, Hildemann LM, Cass GR AND SIMONEIT BRT. 1993e. Quantification of urban organic aerosols at a molecular level: identification, abundance and seasonal variation. Atmos Environ 27A: 13091330 .

Rogge WF, Hildemann LM, Mazurek MA, Cass GR AND SIMONEIT BRT. 1994. Sources of fine organic aerosol. 6. Cigarette smoke in the urban atmosphere. Environ Sci Technol 28: 1375-1388.

Rogge WF, Hildemann LM, Mazurek Ma, Cass GR AND SimoneIt BRT. 1996. Mathematical modeling of atmospheric fine-particle associated primary organic compound concentrations. J Geophys Res 101: 19379-19394.

Rogge WF, Hildemann LM, Mazurek MA, CAss GR AND SIMONEIT BRT. 1997a. Sources of fine organic aerosol. 8. Boilers burning No. 2 distillate fuel oil. Environ Sci Technol 31: 2731-2737.

Rogge WF, Hildemann LM, Mazurek MA, CAss GR AND SIMONEIT BRT. 1997b. Sources of fine organic aerosol. 7. Hot asphalt roofing tar plot plumes. Environ Sci Technol 31: 2726-2730.

Rogge WF, Hildemann LM, Mazurek MA, CAss GR AND SIMONEIT BRT. 1998. Sources of fine organic aerosol. 9. Pine, oak and synthetic log combustion in residential fireplaces. Environ Sci Technol 32: 13-22.

Rogge WF, Medeiros PM And Simoneit BRT. 2006. Organic marker compounds for surface soil and fugitive dust from open lot dairies and cattle feedlots. Atmos. Environ 40: 27-49.

ROMERo R, SiEnRA R AND Richter P. 2002. Efficient screening method for determination of polycyclic aromatic hydrocarbons (PAHs) in airborne particles. Application in real samples of Santiago-Chile metropolitan urban area. Atmos Environ 36: 2375-2381. 
Rushdi A, Ritter G, Grimalt JO AND Simoneit BRT. 2003. Hydrous pyrolysis of cholesterol under various conditions. Org Geochem 34: 799-812.

Sahu SK, Pandit GG and Sadasivan S. 2004. Precipitation scavenging of polycyclic aromatic hydrocarbons in Mumbai, India. Sci Total Environ 318: 245-249.

Samburova V, Szidat S, Hueglin C, Fisseha R, BalTENSPERger U, ZENobi R AND Kalberer M. 2005. Seasonal variation of high molecular weight compounds in the water-soluble organic fraction of urban aerosols. J Geophys Res 110, D23210, doi: 10.1029/2005JD005910.

SANDERSON EG, RAQBi A, VySKOCIL A AND FARANT JP. 2004. Comparison of particulate polycyclic aromatic hydrocarbon profiles in different regions of Canada. Atmos Environ 38: 3417-3429.

Santos CYM, Azevedo DA And Neto FRA. 2002. Selected organic compounds from biomass burning found in the atmospheric particulate matter over sugarcane plantation areas. Atmos Environ 36: 3009-3019.

Santos CYM, Azevedo DA And Neto FRA. 2004. Atmospheric distribution of organic compounds from urban areas near a coal-fired power station. Atmos Environ 38: $1247-1257$.

Satsumabayashi H, KuRita H, YoKouch Y AND UEdA H. 1990. Photochemical formation of particulate dicarboxylic acids under long-range transport in Central Japan. Atmos Environ 24A: 1443-1450.

SAXENA P AND HILDEMANN LM. 1996. Water-soluble organics in atmospheric particles: A critical review of the literature and application of thermodynamics to identify candidate compounds. J Atmos Chem 24: 57-109.

Schauer C, Niessner R and Pöschl U. 2003b. Polycyclic aromatic hydrocarbons in urban air particulate matter: decadal and seasonal trends, chemical degradation and sampling artifacts. Environ Sci Technol 37: 2861-2868.

SCHAUER JJ AND CASS GR. 2000. Source apportionment of winter-time gas-phase and particulate-phase air pollutants using organic compounds as tracers. Environ Sci Technol 34: $1821-1832$

Schauer JJ, Rogge WF, Hildemann LM, Mazurek MA, CASS GR AND Simoneit BRT. 1996. Source apportionment of airborne particulate matter using organic compounds as tracers. Atmos Environ 30: 3837-3855.

Schauer JJ, KleEman MJ, Cass GR and Simoneit BRT. 1999a. Measurement of emissions from air pollution sources. 1. $\mathrm{C}_{1}-\mathrm{C}_{29}$ organic compounds from meat charbroiling. Environ Sci Technol 33: 1566-1577.
Schauer JJ, Kleeman MJ, CAss GR and Simoneit BRT. 1999b. Measurements of emissions from air pollution sources. 2. $\mathrm{C}_{1}$ through $\mathrm{C}_{30}$ organic compounds emitted from medium duty diesel trucks. Environ Sci Technol 33: $1578-1587$.

Schauer JJ, Kleeman MJ, Cass GR and Simoneit BRT. 2001. Measurement of emissions from air pollution sources. 3. $\mathrm{C}_{1}-\mathrm{C}_{29}$ organic compounds from fireplace combustion of wood. Environ Sci Technol 35: 1716-1728.

Schauer JJ, Fraser MP, CASS GR AND Simoneit BRT. 2002a. Source reconciliation of atmospheric gas-phase and particle-phase pollutants during a severe photochemical smog episode. Environ Sci Technol 36: 3806-3814.

Schauer JJ, KleEman MJ, Cass GR and Simoneit BRT. 2002b. Measurement of emissions from air pollution sources. 4. $\mathrm{C}_{1}-\mathrm{C}_{27}$ organic compounds from cooking with seed oils. Environ Sci Technol 36: 567-575.

Schauer JJ, Kleeman J, Cass GR and Simoneit BRT. 2002c. Measurement of emissions from air pollution sources. 5. $\mathrm{C}_{1}-\mathrm{C}_{32}$ organic compounds from gasoline-powered motor vehicles. Environ Sci Technol 36: 1169-1180

SChAuer JJ ET AL. 2003a. ACE-Asia intercomparison of a thermal-optical method for the determination of particlephase organic ad elemental carbon. Environ Sci Technol 37: 993-1001.

SChefuß E, Rateyer V, StuUt JBW, Jansen JHF AND DAMSTÉ JSS. 2003. Carbon isotope analyses of $n$ alkanes in dust from the lower atmosphere over the central eastern Atlantic. Geochim Cosmochim Acta 67: 17571767.

Schenelle-Kreis J, Gebefügi I, Welzl G, Jaensch T AND Kettrup A. 2001. Occurrence of particle-associated polycyclic aromatic compounds in ambient air of the city of Munich. Atmos Environ 35: 71-81.

SCHMIDL C. 2005. $\mathrm{PM}_{10}$ - Quellenprofile von holzrauchemissionen aus kleinfeuerungen. PhD Thesis, Vienna, University of Technology.

Schneider E, Krenmayr P And Varmuza K. 1990. A routine method for the analysis of mononitroPAH in immission and emission samples. Monats Chem 121: 393-401.

SEINFIELD JH AND PANDIS SN. 1998. Organic atmospheric aerosols. In: ATMOSPHERIC AND PHYSICS: FROM AIR Pollution to Climate Change, USA, J Wiley \& Sons, p. 700-751. 
ShanNigrahi AS, FukUShima T AND OZAKi N. 2005. Comparison of different methods for measuring dry deposition fluxes of particulate matter and polycyclic aromatic hydrocarbons (PAHs) in the ambient air. Atmos Environ 39: 653-662.

Sheesley RJ, Schauer JJ, Chowdhury Z, Cass GR AND SIMONEIT BRT. 2003. Characterization of organic aerosols from combustion of biomass indigenous to South Asia. J Geophys Res 108(D9): No. 4285, AAC 8.1-8.15.

SheEsley RJ, Schauer JJ, BeAn E AND Kensi D. 2004. Tends in secondary organic aerosol at a remote site in Michigan's Upper Peninsula. Environ Sci Technol 38: 6491-6500.

Shimmo M, Adler H, Hyotyläinen T, Hartonen K, Kulmala M and RiekKola ML. 2002. Analysis of particulate polycyclic aromatic hydrocarbons by on-line coupled supercritical fluid extraction-liquid chromatography-gas chromatography-mass spectrometry. Atmos Environ 36: 2985-2995.

Shimmo M, Jantti J, Aalto P, Hartonen K, HyotyLainen T, Kulmala M And RiekKola ML. 2004a. Characterisation of organic compounds in aerosol particles from a Finnish forest by on-line coupled supercritical fluid extraction-liquid chromatography-gas chromatography-mass spectrometry. Anal Bioanal Chem 378: 1982-1990.

Shimmo M, SaArnio K, Aalto P, Hartonen K, Hyötyläinen T, Kulmala M AND RiekKola ML. 2004b. Particle size distribution and gas-particle partition of polycyclic aromatic hydrocarbons in Helsinki urban area. J Atmos Chem 47: 223-241.

Sicre MA AND Peltzer ET. 2004. Lipid geochemistry of remote aerosols from the southwestern Pacific Ocean sector. Atmos Environ 38: 1615-1624.

Sicre MA, Marty JC, Saliot A, Aparicio X, Grimalt J AND Albaiges J. 1987. Aliphatic and aromatic hydrocarbons in different sized aerosols over the Mediterranean Sea: occurrence and origin. Atmos Environ 21: $2247-$ 2259.

Sierau B, Stratmann F, Pelzing M, Neusüß C, HofMANN D AND WILCK M. 2003. A condensation-growth and impaction method for rapid off-line chemical-characterization of organic submicrometer atmospheric aerosol particles. J Aerosol Sci 34: 225-241.

Silva PJ AND PRATHER KA. 1997. On-line characterization of individual particles from automobile emissions. Environ Sci Technol 31: 3074-3080.
SimciK MF, EISENREICH SJ AND LIOY PJ. 1999. Source apportionment and source/sink relationships of PAHs in the coastal atmosphere of Chicago and Lake Michigan. Atmos Environ 33: 5071-5079.

Simó R, Colom-Altés M, Grimalt JO And Albaigés J. 1991. Background levels of atmospheric hydrocarbons, sulphate and nitrate over the western Mediterranean. Atmos Environ 25A: 1463-1471.

SIMONEIT BRT. 1984. Organic matter of the troposphere-III. Characterization and sources of petroleum and pyrogenic residues in aerosols over the Western United States. Atmos Environ 18: 51-67.

SIMONEIT BRT. 1989. Organic matter of the troposphere-V. Application of molecular analysis to biogenic emissions into the troposphere for source reconciliations. J Atmos Chem 8: 251-275.

SIMONEIT BRT. 1997. Compound-specific carbon isotope analysis of individual long-chain alkanes and alkanoic acids in Harmattan aerosols. Atmos Environ 31: 22252233.

SIMONEIT BRT. 1999. A review of biomarker compounds as source indicators and tracers for air pollution. Environ Sci Pollut Res 6: 159-169.

SIMONEIT BRT. 2002. Biomass burning - a review of organic tracers for smoke from incomplete combustion. Appl Geochem 17: 129-162.

Simoneit BRT AND Elias VO. 2000. Organic tracers from biomass burning in atmospheric particulate matter over the ocean. Mar Chem 69: 301-312.

Simoneit BRT And Elias VO. 2001. Detecting organic tracers from biomass burning in the atmosphere. Mar Pollut Bull 42: 805-810.

SimOneIt BRT AND MAZUREK MA. 1982. Organic matter of the troposphere-II. Natural background of biogenic lipid matter in aerosols over the rural Western United States. Atmos Environ 16: 2139-2159.

Simoneit BRT AND MAZUREK MA. 1989. Organic tracers in ambient aerosols and rain. Aerosol Sci Technol 10: 267-291.

Simoneit BRT, Cheste R And Eglinton G. 1977. Biogenic lipids in particulates from the lower atmosphere over the eastern Atlantic. Nature 267: 682-685.

Simoneit BRT, Cox RE AND Standley LJ. 1988. Organic matter of the troposphere-IV. Lipids in Harmattan aerosols of Nigeria. Atmos Environ 22: 983-1004.

Simoneit BRT, CARdoso JN AND Robinson N. 1990. 
An assessment of the origin and composition of higher molecular weight organic matter in aerosols over Amazonia. Chemosphere 21: 1285-1301.

Simoneit BRT, Sheng G, Chen X, Fu J, Zhang J And XU Y. 1991a. Molecular marker study of extractable organic matter in aerosols from urban areas of China. Atmos Environ 25A: 2111-2129.

Simoneit BRT, Cardoso JN ANd Robinson N. 1991b. An assessment of terrestrial higher molecular weight lipid compounds in aerosol particulate matter over the South Atlantic from about $30-70^{\circ} \mathrm{S}$. Chemosphere 23: 447-465.

Simoneit BRT, Crisp PT, Mazurek MA AND STANDLEY LJ. 1991c. Composition of extractable organic matter of aerosols from the Blue Mountains and southeast coast of Australia. Environ Int 17: 405-419.

Simoneit BRT, Rogge WF, Mazurek MA, Standley LJ, Standley LM, Hildemann LM and Cass GR. 1993. Lignin pyrolysis products, lignans and resin acids as specific tracers of plant classes in emissions from biomass combustion. Environ Sci Technol 27: 2533-2541.

Simoneit BRT, Abas MR, CAss GR, Rogge WF, MaZureK MA, Standley LJ And Hildemann LM. 1996. Natural organic compounds as tracers for biomass combustion in aerosols. In: LEVINE JS, Biomass Burning and Global Change, Vol. 1, Remote Sensing, Modeling and Inventory Development and Biomass Burning in Africa. Cambridge, MA: MIT Press, p. 509-518.

Simoneit BRT, Schauer JJ, Nolte CG, Oros DR, Elias VO, Fraser MP, Rogge WF and Cass GR. 1999. Levoglucosan, a tracer for cellulose in biomass burning and atmospheric particles. Atmos Environ 33: 173-182.

Simoneit BRT, Rogge WF, Mazurek MA, Standley LJ, Hildemann LM and CASS GR. 2000. Molecular characterization of smoke from campfire burning of pine wood (Pinus elliotti). Chemosphere: Global Change Sci 2: $101-110$.

Simoneit BRT, Rushdi A, BIN ABAs MR AND Didyk BM. 2003a. Alkyl amides and nitriles as novel tracers for biomass burning. Environ Sci Technol 37: 16-21.

SimoneIt BRT, KobAYASHI M, KAWAMURA K AND Mochida M. 2003b. Saccharides, lipids and oxidation products in Asian dust and marine aerosols of the East asia/Pacific region. Geochim Cosmochim Acta 67: A437.

Simoneit BRT, Kobayashi M, Mochida M, KaWAMURA K, LEE M, Lim HJ, TURPIN BJ AND KomAZAKI Y. 2004a. Composition and major sources of or- ganic compounds of aerosols particulate matter sampled during the ACE-Asia campaign. J Geophys Res 109: D19S10, doi:10.1029/2004JD004598.

Simoneit BRT, Elias VO, Kobayashi M, Rushdi AI, Medeiros PM, Rogge WF And Didyk BM. 2004b. Sugars-Dominant water-soluble organic compounds in soils and characterization as tracers in atmospheric particulate matter. Environ Sci Technol 38: 5939-5949.

Simoneit BRT, Medeiros PM ANd Didy K BM. 2005. Combustion products of plastics as indicators for refuse burning in the atmosphere. Environ Sci Technol 39: 69616970.

Simpson CD, Dills RL, Katz BS and Kalman DA. 2004. Determination of levoglucosan in atmospheric fine particulate matter. J Air Waste Manage Assoc 54: 689694.

Simpson CD, Paulsen M, Dills RL, Liu LJ, Kalman DA. 2005. Determination of methoxyphenols in ambient atmospheric particulate matter: tracers for wood combustion. Environ Sci Technol 39: 631-637.

Sin DW, Fung WH AND LAM CH. 2002. Measurement of carbonaceous aerosols: validation and comparison of a solvent extraction-gas chromatographic method and a thermal optical transmittance method. Analyst 127: 614622.

Sklorz M, Schnelle-Kreis J, LiU Y, ORAsche J AND Zimmermann R. 2007. Daytime resolved analysis of polycyclic aromatic hydrocarbons in urban aerosol samples - Impact of sources and meteorological conditions. Chemosphere 67: 934-943.

SMith DJT AND HARRISON RM. 1996. Concentrations, trends and vehicle source profile of polynuclear aromatic hydrocarbons in the U.K. atmosphere. Atmos Environ 30: $2513-2525$

SMITH DJT AND HARRISON RM. 1998. Polycyclic aromatic hydrocarbons in atmospheric particles. In: HARRISon R And VAn Grieken R (Eds), Atmospheric Particles, IUPAC Series on Analytical and Physical Chemistry of Environmental Systems, England, J Wiley \& Sons 5: 253-294.

Smith DJT, Harrison RM, LuHana L, Pio CA, CASTRO LM, NAWAZ-TARIQ M, HaYAT S AND QURAISHI T. 1996. Concentrations of particulate polycyclic aromatic hydrocarbons and metals collected in Lahore, Pakistan. Atmos Environ 30: 4031-4040.

Spanke J, Rannik U, Forkel R, Nigge W and HoffMANN T. 2001. Emission fluxes and atmospheric degra- 
dation of monoterpenes above a boreal forest: field measurements and modelling. Tellus Ser B 53: 406-422.

STANDLEY L AND SIMONEIT BRT. 1994. Resin diterpenoids as tracers for biomass combustion aerosols. J Atmos Chem 18: $1-15$.

Stephanou E and Stratigakis N. 1993. Determination of anthropogenic and biogenic organic compounds on airborne particles: flash chromatographic fractionation and capillary gas chromatographic analysis. J Chromatogr A 644: 141-151.

Takada H, Onada T, Harada M and Ogura N. 1990. Determination of polycyclic aromatic hydrocarbons in urban street dusts and their source materials by capillary gas chromatography. Environ Sci Technol 24: 1179-1185.

TAKada H, OnAda T, Harada M ANd Ogura N. 1991. Distributions and sources of polycyclic aromatic hydrocarbons (PAHs) in street dust from the Tokyo metropolitan area. Sci Total Environ 107: 45-69.

TAmamura S, Sato T, Ota Y, Wang X, TANG N And HAYAKAWA K. 2007. Long-range transport of polycyclic aromatic hydrocarbons (PAHs) from the eastern Asian continent to Kanazawa, Japan with Asian dust. Atmos Environ 41: 2580-2593.

TANG H, Richards G, Benner CL, TuOMinen JP, LEE ML, Lewis EA, Hansen L AND Eatough DJ. 1990. Solanesol - a tracer for environmental tobacco-smoke particles. Environ Sci Technol 24: 848-852.

TANG N ET AL. 2005. Polycyclic aromatic hydrocarbons and nitropolycyclic aromatic hydrocarbons in urban air particulates and their relationship to emission sources in the Pan-Japan Sea countries. Atmos Environ 39: 5817 5826.

TANG XL, Bi XH, Sheng GY, TAN JH AND FU JM. 2006. Seasonal variation of particle size distribution of $n$-alkanes and polycyclic aromatic hydrocarbons (PAHs) in urban aerosol of Guangzhou, China. Environ Monit Assess 117: 193-213.

TASDEMIR Y AND ESEN F. 2007. Dry deposition fluxes and deposition velocities of PAHs at an urban site in Turkey. Atmos Environ 41: 1288-1301

Teil MJ, Blanchard M and Chevreuil M. 2006. Atmospheric fate of phthalate esters in an urban area (ParisFrance). Sci Total Environ 354: 212-223.

THOMPSON DS AND MURPHY DM. 1994. Analyzing single aerosol particles in real time. Chemtech 24: 30-35.

Thuren A AND LARsson P. 1990. Phthalate esters in the Swedish atmosphere. Environ Sci Technol 24: 554-559.
Tobias HJ AND ZIEMANN PJ. 2000. Thermal desorption mass spectrometric analysis of organic aerosol formed from reactions of 1-tetradecene and $\mathrm{O}_{3}$ in the presence of alcohols and carboxylic acids. Environ Sci Technol 34: 2105-2115.

TOlOcka MP, Jang M, GNTER JM, KAMENS RM AND JOHNSTON MV. 2004. Formation of oligomers in secondary organic aerosol. Environ Sci Technol 38: 14281434.

Tsai JH, Peng BH, Lin ST AND LeE DZ. 1995. Effects of open-air burning of metal scrap on ambient polycyclic aromatic hydrocarbon concentrations. Sci Total Environ 164: 9-17.

Tsapakis M and Stephanou EG. 2003. Collection of gas and particle semi-volatile organic compounds: use of an oxidant denuder to minimize polycyclic aromatic hydrocarbons degradation during high-volume air sampling. Atmos Environ 37: 4935-4944.

Tsapakis M, Lagoudaki E, Stephanou EG, KavouRas IG, Koutrakis P, Oyola P AND Baer D. 2002. The composition and sources of $\mathrm{PM}_{2.5}$ organic aerosol in two urban areas of Chile. Atmos Environ 36: 3851-3863.

TURPIN BJ AND HUNTZICKER JJ. 1995. Identification of secondary organic aerosol episodes and quantification of primary and secondary organic aerosol concentrations during SCAQS. Atmos Environ 29A: 3527-3544.

Turpin BJ, SAXENA P AND ANDrews E. 2000. Measuring particulate organics in the atmosphere: problems and prospects. Atmos Environ 34: 2983-3013.

VARga B, Kiss G, GANSZKY I, Gelencsér A AND KRIVÁCSY Z. 2001. Isolation of water soluble organic matter from atmospheric aerosol. Talanta 55: 561-572.

Vasconcellos PC, Zacarias D, Pires MAF, Pool CF AND CARVAlHo LRF. 2003. Measurements of polycyclic aromatic hydrocarbons in airborne particles from the metropolitan area of São Paulo City, Brazil. Atmos Environ 37: 3009-3018.

Venkatachari P, Zhou L, Hopke PK, Schwab Jj, Demerjian KL, Weimer S, Hogrefe O, Felton D AND RATTIGAN O. 2006. An intercomparison of measurement methods for carbonaceous aerosol in the ambient air in New York City. Aerosol Sci Technol 40: 788-795.

WANG G AND KaWAmura K. 2005. Molecular Characteristics of urban organic aerosols from Nanjing: A case study of a mega-city in China. Environ Sci Technol 39: 7430-7438.

WANG G, NiU S, LIU C AND WANG L. 2002. Identification 
of dicarboxylic acids and aldehydes of $\mathrm{PM}_{10}$ and $\mathrm{PM}_{2.5}$ aerosols in Nanjing, China. Atmos Environ 36: 19411950.

Wang G, Kawamura K, Lee S, Ho K and Cao J. 2006 a. Molecular, seasonal and spatial distribution of organic aerosols from fourteen Chinese cities. Environ Sci Technol 40: 4619-4625.

Wang G, Kawamura K, Watanabe T, Lee S, Ho K and CAO J. 2006b. High loading and source strengths of organic aerosols in China. Geophys Res Lett 33, L22801, doi:10.1029/2006/GL027624.

WANG G, KaWAMURa K, ZhaO X, Li Q, Dai Z AND NiU H. 2007. Identification, abundance and seasonal variation of anthropogenic organic aerosols from a mega-city in China. Atmos Environ 41: 407-416.

WÄngBerg I, BARnes I AND Becker KH. 1997. Product and mechanistic study of the reaction of $\mathrm{NO}_{3}$ radicals with $\alpha$-pinene. Environ Sci Technol 31: 2130-2135.

Waterman D, Horsfield B, Leistner F, Hall K AND SMITH S. 2000. Quantification of polycyclic aromatic hydrocarbons in the NIST Standard Reference Material (SRM1649A) urban dust using thermal Desorption GC/ MS. Anal Chem 72: 3563-3567.

Watson JG AND ChOW JC. 2002. Comparison and evaluation of in situ and filter carbon measurements at the Fresno Supersite. J Geophys Res 107 (D21), Art. N 8341, doi:10.1029/2001JD000573.

Watson JG, Zhu T, Chow JC, Engelbrecht J, FuJITA EM AND WILSON WE. 2002. Receptor modeling application framework for particle source apportionment. Chemosphere 49: 1093-1136.

Wauters E, Vangaever F, Sandra P and Verzele M. 1979. Polar organic fraction of air particulate matter. J Chromatogr 170: 133-138.

Welthagen W, Schnelle-Kreis J AND ZimmermanN R. 2003. Search criteria and rules for comprehensive two-dimensional gas chromatography-time-of-flight mass spectrometry analysis of airborne particulate matter. J Chromatogr A 1019: 233-249.

Westerholm R, Stenberg U and Alsberg T. 1988. Some aspects of the distribution of polycyclic aromatic hydrocarbons $(\mathrm{PAH})$ between particles and gas phase from diluted gasoline exhausts generated with the use of a dilution tunnel and its validity for measurement in ambient air. Atmos Environ 22: 1005-1010.

Westerholm R, Almén J, Li H, RannUg U and Rosén Å. 1992. Exhaust emissions from gasoline-fuelled light duty vehicles operated in different driving conditions: a chemical and biological characterization. Atmos Environ 26B: 79-90.

Wilson NK, MCCURdy TR ANd ChUANG JC. 1995. Concentrations and phase distributions of nitrated and oxygenated polycyclic aromatic-hydrocarbons in ambient air. Atmos Environ 29: 2575-2584.

Xia X And Hopke PK. 2006. Seasonal variation of 2methyltetrols in ambient air samples. Environ Sci Technol 40: 6934-6937.

YANG H, Li Q AND YU JZ. 2003. Comparison of two methods for the determination of water-soluble organic carbon in atmospheric particles. Atmos Environ 37: 865-870.

YANG H, YU JZ, Ho SSH, XU J, WU WS, WAN CH, WANG X AND WANG L. 2005a. The chemical composition of inorganic and carbonaceous materials in $\mathrm{PM}_{2.5}$ in Nanjing, China. Atmos Environ 39: 3735-3749.

YANG HH, LeE WJ, Chen SJ AND LAI SO. 1998. PAH emission from various industrial stacks. J Hazard Mater 60: 159-174.

YANG HH, Hsieh LT, LiU CH AND Mi HH. 2005b. Polycyclic aromatic hydrocarbon emissions from motorcycles. Atmos Environ 39: 17-25.

YANG HH, Lo MH, LAN JCW, WANG JS AND HSIEH DPH. 2007. Characteristics of trans,trans-2,4-decadienal and polycyclic aromatic hydrocarbons in exhaust of diesel engine fuelled with biodiesel. Atmos Environ 3373-3380.

Yassaa N, Meklati BY, Cecinato A and Marino F. 2001a. Organic aerosols in urban and waste landfill of Algiers metropolitan area: occurrence and sources. Environ Sci Technol 35: 306-311.

Yassaa N, Meklati BY, Cecinato A and Marino F. 2001b. Particulate $n$-alkanes, $n$-alkanoic acids and polycyclic aromatic hydrocarbons in the atmosphere of Algiers City Area. Atmos Environ 35: 1843-1851.

Yassaa N, Meklati BY and Cecinato A. 2001c. Chemical characteristics of organic aerosols in Algiers city area: influence of a fat manufacture plant. Atmos Environ 34: 6003-6013.

Yu J, GRIFFin RJ, Cocker DR, Flagan RC AND SEINFELD JH. 1999. Observation of gaseous and particulate products of monoterpene oxidation in forest atmospheres. Geophys Res Lett 26: 1145-1148.

Yu JZ, TUNG JWT, Wu AWM, LAU AKH, LOUIE PKK AND FUNG CH. 2004. Abundance and seasonal characteristics of elemental and organic carbon in Hong Kong $\mathrm{PM}_{10}$. Atmos Environ 38: 1511-1521. 
Yue Z AND Fraser MP. 2004. Polar organic compounds measured in fine particulate matter during TexAQS 2000. Atmos Environ 38: 3253-3261.

ZAPPOLI S ET AL. 1999. Inorganic, organic and macromolecular components of fine aerosol in different areas of Europe in relation to their water solubility. Atmos Environ 33: 2733-2743.

Zdráhal Z, Oliveira J, Vermeylen R, Claeys M AND MAENhaUt W. 2002. Improved method for quantitating levoglucosan and related monosacharide anhydrides in atmospheric aerosols and application to samples from urban and tropical locations. Environ Sci Technol 36: $747-753$.

Zheng M, WAN TSM, FAng M AND WANG F. 1997. Characterization of the non-volatile organic compounds in the aerosols of Hong-Kong. Identification, abundance and origin. Atmos Environ 31: 227-237.

Zheng M, FAng M, WANG F And To KL. 2000. Characterization of the solvent extractable organic compounds in $\mathrm{PM}_{2.5}$ aerosols in Hong Kong. Atmos Environ 34: 2691-2702.

Zheng M, Cass GR, Schauer JJ And Edgerton ES. 2002. Source apportionment of $\mathrm{PM}_{2.5}$ in the Southeastern United States using solvent-extractable organic compounds as tracers. Environ Sci Technol 36: 2361-2371.
Zheng M, SAlmon LG, Schauer JJ, Zeng L, Kiang CS, ZHANG Y AND CASS GR. 2005. Seasonal trends in $\mathrm{PM}_{2.5}$ source contributions in Beijing, China. Atmos Environ 39: 3967-3976.

Zhu Y, Hinds WC, Shen S And Sioutas C. 2004. Seasonal trends of concentration and size distribution of ultrafine particles near major highways in Los Angeles. Aerosol Sci Technol 38 (Suppl 1): 5-13.

ZIELINSKA B. 2002. What current sampling and measurement technologies are available to measure marker components? How can they be practically applied at urban and remote locations? In: RICHARD T, WATSON J, EDGAR R, JOHNSON D AND REBER J (Eds), Secondary organic aerosols research strategy to apportion biogenic/anthropogenic sources of SOA. Reno, Nevada: Desert Research Institute, p. 23-26.

Zielinska B, ARey J, AtKinson R And Wiener AM. 1989. The nitroarenes of molecular weight 247 in ambient particulate samples collected in southern California. Atmos Environ 23: 223-229.

Zielinska B, Sagebiel J, Arnott WP, Rogers CF, Kelly KE, Wagner DA, Lihhty JS, SARofim AF AND PAlmer G. 2004. Phase and size distribution of polycyclic aromatic hydrocarbons in diesel and gasoline vehicle emissions. Environ Sci Technol 38: 2557-2567. 